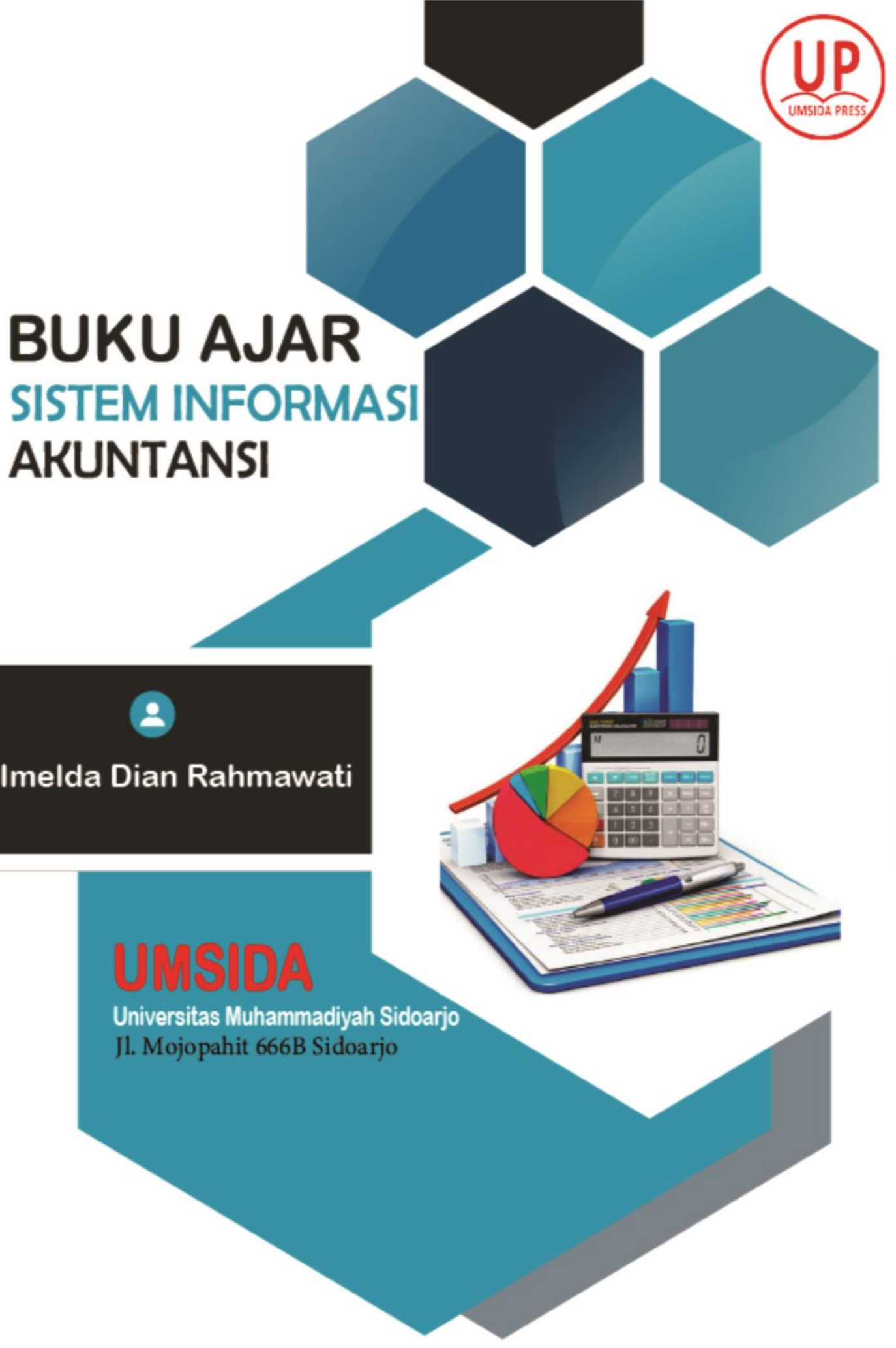




\title{
BUKU AJAR \\ Sistem Informasi Akuntansi
}

\author{
Penulis \\ Imelda Dian Rahmawati.,SE.M.Ak.Ak
}

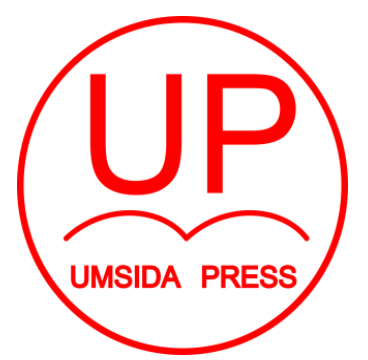

\author{
Diterbitkan oleh \\ UMSIDA PRESS \\ Jl. Mojopahit 666 B Sidoarjo \\ ISBN: 978-602-5914-07-2 \\ Copyright@2018. \\ Authors \\ All rights reserved
}




\section{BUKU AJAR}

\section{Sistem Informasi Akuntansi}

\section{Penulis :}

Imelda Dian Rahmawati.,SE.M.Ak.Ak

ISBN : 978-602-5914-07-2

\section{Editor :}

Septi Budi Sartika, M.Pd

M. Tanzil Multazam , S.H., M.Kn.

\section{Copy Editor :}

Fika Megawati, S.Pd., M.Pd.

Design Sampul dan Tata Letak :

Mochamad Nashrullah, S.Pd

\section{Penerbit :}

UMSIDA Press

\section{Redaksi :}

Universitas Muhammadiyah Sidoarjo

Jl. Mojopahit No 666B

Sidoarjo, Jawa Timur

Cetakan pertama, Agustus 2018

(C) Hak cipta dilindungi undang-undang

Dilarang memperbanyak karya tulis ini dengan suatu apapun tanpa ijin tertulis dari penerbit. 


\section{KATA PENGANTAR}

Puji Syukur kehadirat Allah swt atas rahmat dan karuniaNya buku ajar Sistem Informasi Akuntansi ini bisa terselesaikan. Buku ini memperkenalkan tentang pengertian sistem informasi akuntansi dan prakteknya didalam perusahaan. Buku ini juga menguraikan sistem pengendalian intern perusahaan yang sangat bermanfaat untuk menjaga dan mengamankan aset perusahaan yang disesuaikan dengan transaksi yang terjadi dan perkembangan teknologi infomasi saat ini. Semoga dengan adanya buku ajar ini bisa memberikan kontribusi pada perkembangan Sistem Informasi Akuntansi di Indonesia agar bisa menjadi bagian dari perkembangan dunia akuntansi yang dinamis. Semoga Bermanfaat.

Sidoarjo, Januari 2018

Penulis

Imelda D. Rahmawati 


\section{DAFTAR ISI}

Identitas Buku 2

Kata Pengantar 3

$\begin{array}{ll}\text { Daftar isi } & 4\end{array}$

CAPAIAN PEMBELAJARAN MATA KULIAH SISTEM 6 INFORMASI AKUNTANSI

\section{BAGIAN 1}

KONSEP DASAR SISTEM INFORMASI AKUNTANSI 7

DAN METODOLOGI PENGEMBANGANNYA

1.1. Pengertian, tujuan, karakteristik dan komponen 7 utama Sistem Informasi Akuntansi (SIA)

1.2. Tujuan umum sistem informasi akuntansi

1.3. Mengapa Perlu Mempelajari SIA? $\quad 15$

1.4. Hubungan SIA dengan SIM 17

1.5. Analisis sistem, desain sistem dan implementasi 19 sistem

1.6. Bagan alir 28

BAGIAN 2

SISTEM PENGENDALIAN INTERN (SPI)

2.1. Pengertian, unsur-unsur, tujuan dan lingkungan 34 SPI

2.2. Ciri-ciri Sistem Pengendalian Intern yang Memadai 35 
2.4. Pendekatan perancangan SPI 43

2.5. Pengendalian Intern Akuntansi dalam PDE 46 lingkungan pengendalian

BAGIAN 3

KONSEP DASAR UNSUR-UNSUR SISTEM AKUNTANSI POKOK PADA PERUSAHAAN

3.1. Konsep dasar formulir 53

3.2. Laporan Keuangan 57

3.3. Proses Dan Siklus Akuntansi 61

3.4. Karakteristik Sistem Informasi Akuntansi 63

BAGIAN 4

SISTEM PENJUALAN KREDIT DAN SISTEM AKUNTANSI PIUTANG

4.1. Sistem informasi siklus pendapatan/Penerimaan

67 Kas

4.2. Informasi yang Diperlukan oleh Manajemen $\quad 78$

4.3. Catatan Akuntansi yang digunakan $\quad 80$

4.4. Unsur Pengendalian Intelrn 83

BAGIAN $5 \quad 106$

SISTEM AKUNTANSI PEMBELIAN, PENGELUARAN KAS

5.1. Sistem informasi siklus pembelian 106

5.2.Siklus Pengeluaran Kas $\quad 115$

5.3.Sistem Akuntansi Pengeluaran Kas $\quad 120$

BAGIAN $6 \quad 127$ 
6.1. Sistem informasi siklus MSDM/ Penggajian 127

6.2. Flowchart siklus penggajian 146

6.3. Opsi outsourcing: biro jasa penggajian dan 148 organisasi pengusaha professional

BAGIAN 7

SISTEM AKUNTANSI BIAYA

7.1. Sistem Akuntansi Biaya dan Produksi 154

7.2. Formulir yang dibutuhkan dan Flowchart 159

BAGIAN $8 \quad 162$

PENGEMBANGAN SISTEM INFORMASI AKUNTANSI

8.1. Perkembangan Terkini Teknologi Informasi 162 Akuntansi

8.2. Penerapan Tekhnologi Informasi dalam Organisasi 167

8.3. Pengaruh Perkembangan Teknologi Informasi 169 Akuntansi

8.4. Sistem Pelaporan Keuangan Berbasis XBRL 171

8.5. Bagaimanakah XBRL di Indonesia 175

Biodata Penulis $\quad 177$

$\begin{array}{ll}\text { Daftar Pustaka } & 178\end{array}$ 
CAPAIAN PEMBELAJARAN MATA KULIAH SISTEM INFORMASI AKUNTANSI

Setelah mengikuti Mata Kuliah ini, mahasiswa diharapkan mampu:

1. Menjunjung tinggi sikap integritas dan kode etik serta terjaminnya integritas data dan informasi.

2. Menyajikan teknologi dan pengendalian internal yang baik dalam pembuatan sistem informasi akuntansi.

3. Menerapkannya dalam berbagai praktek akuntansi dengan menjunjung tinggi kode etik profesi. 


\section{BAGIAN 1}

KONSEP DASAR SISTEM INFORMASI AKUNTANSI DAN METODOLOGI PENGEMBANGANNYA

\section{TUJUAN INSTRUKSIONAL UMUM}

Mampu menjelaskan sistem, data, informasi, sistem informasi akuntansi. Pengembangan sistem dan teknik dokumentasi Mampu menjelaskan sistem, data, informasi, sistem informasi akuntansi. Pengembangan sistem dan teknik dokumentasi

\section{SUB BAGIAN}

1.1. Pengertian, tujuan, karakteristik dan komponen utama Sistem Informasi Akuntansi (SIA)

Sistem informasi akuntansi sangat diperlukan oleh sebuah perusahaan yang bergerak dalam bidang apapun, karena mengandung sebuah proses untuk melaporkan kondisi keuangan perusahaan secara akurat dan benar untuk semua pihak yang membutuhkan. Proses tersebut berkaitan dengan teknologi informasi untuk memajukan usaha atau bisnis.

Sistem Informasi adalah suatu sistem yang menggunakan teknologi komputer untuk menyajikan 
informasi kepada para pemakainya dalam mengambil keputusan. Sistem informasi pada umumnya memiliki enam komponen utama yaitu :

1. Masukan, meliputi data (seperti : data transaksi harian) serta metode dan media yang digunakan untuk memasukkan data tersebut

2. Model, meliputi model logika matematik yang digunakan untuk mengolah data sehingga menghasilkan keluaran yang dikehendaki

3. Keluaran, yaitu informasi yang bermutu yang dihasilkan dari proses pengoalahan, baik berupa laporan ataupun dokumen

4. Blok Teknologi, berupa alat yang digunakan untuk menangkap masukan, menjalankan model \& sistem informasi serta menghasilkan keluaran yang diinginkan

5. Basis Data yaitu tempat menyimpan data yang digunakan untuk kebutuhan pemakai

6. Pengendalian, berfungsi untuk melindungi sistem informasi dari segala macam hambatan / ancaman

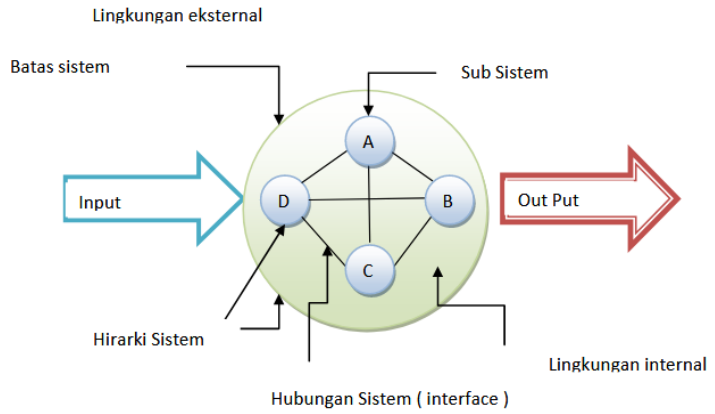


Sistem Informasi terdiri dari beberapa jenis, yaitu :

1. Sistem Pengolahan Data Elektronik (Elektronic Data Processing / EDP)

Sistem Pengolahan Data Elektronik adalah suatu system pengolahan data transaksi-transaksi dalam suatu perusahaan dengan memanfaatkan tegnologi komputer dalam suatu organisasi

2. Sistem Informasi Manajemen (Manajemen Information Systems / MIS)

Sistem Informasi Manajemen adalah kumpulan dari manusia dan sumber daya modal (mesin) didalam suatu organisasi yang bertanggungjawab mengumpulkan dan mengolah data untuk menyediakan informasi yang berguna didalam mendukung operasi manajemen dan pengambilan keputusan manajemen. SIM terdiri dari beberapa SI, antara lain : Sistem Informasi Pemasaran, Sistem Informasi Produksi, Sistem Informasi Sumber Daya Manusia, Sistem Informasi Keuangan, Sistem Informasi Akuntansi

3. Sistem Pendukung Keputusan (Decision Support Systems / DSS)

Sistem Pendukung Keputusan yaitu kelompok system informasi yang memaparkan sistem pemrosesan transaksi dan berinteraksi dengan bagian lain dari system secara 
keseluruhan yang digunakan untuk menunjang aktivitas pembuatan keputusan para manajer dan pekerja terdidik yang lain dalam suatu perusahaan

4. Sistem Pakar (Expert Systems / ES)

Sistem Pakar yaitu sistem informasi berupa program komputer yang berisikan keahlian manusia untuk dapat digunakan dalam memberikan nasehat, rekomendasi dan hasil diagnosis terhadap suatu masalah dalam bidangbidang tertentu

5. Sistem Informasi Eksekutif (Executive Information Systems / EIS)

Sistem Informasi Eksekutif yaitu sistem terkomputerisasi yang memberi eksekutif akses yang mudah ke informasi internal dan informasi eksternal yang relevan dengan faktor keberhasilannya

6. Sistem Informasi Eletronik Bisnis (e-Business Information Systems)

Sistem Informasi Eletronik Bisnis yaitu system terkomputerisasi yang berbasiskan internet didalam melakukan kegiatan bisnis

Sistem informasi akuntansi menurut Mulyadi adalah organisasi formulir, catatan, dan laporan yang dikoordinasi sedemikian rupa untuk menyediakan informasi keuangan yang 
dibutuhkan oleh manajemen guna memudahkan pengelolaan perusahaan (2001). Sedangkan menurut Nugroho Widjajanto (2001), sistem informasi akuntansi adalah susunan formulir, catatan, peralatan termasuk komputer dan perlengkapannya serta alat komunikasi, tenaga pelaksanaannya dan laporan yang terkoordinasi secara erat yang didesain untuk mentransformasikan data keuangan menjadi informasi yang dibutuhkan manajemen. Dari sini dapat disimpulkan bahwa sistem informasi akuntansi (SIA) merupakan suatu sistem yang terdiri dari berbagai formulir, catatan dan laporan yang telah disusun dan menghasilkan suatu informasi keuangan yang dibutuhkan oleh perusahaan. Dengan demikian manajemen perusahaan dapat melihat keuangan dengan jelas melalui sistem tersebut. Selain itu, manajemen juga dapat mengontrol kinerja dari sistem yang digunakan.

\section{Fungsi Sistem Informasi Akuntansi}

Sistem keuangan yang menyediakan informasi memiliki beberapa fungsi dalam keberlangsungan usaha. Berikut beberapa fungsinya:

a. Mengumpulkan semua data kegiatan bisnis perusahaan dan menyimpan data tersebut secara efektif dan efisien. Selain itu, SIA juga dapat mencatat semua sumber daya yang berpengaruh terhadap usaha tersebut dan semua pihak yang terkait. Dengan fungsi ini, tidak akan ada suatu hal dalam perusahaan yang tidak tercatat.

b. Mengambil data yang diperlukan dari berbagai sumber dokumen yang berkaitan dengan aktivitas bisnis.

c. Membuat dan mencatat data transaksi dengan benar ke dalam jurnal-jurnal yang diperlukan dalam proses 
akuntansi sesuai dengan urutan dan tanggal terjadinya transaksi. Pencatatan ini bertujuan untuk mempermudah pihak-pihak yang membutuhkan dalam pengecekan semua transaksi. Sehingga jika terjadi suatu kesalahan dapat dikoreksi dengan mudah dan dapat diketahui penyebabnya dengan cepat.

d. Fungsi utama SIA adalah mengubah sekumpulan data menjadi informasi keuangan yang dibutuhkan perusahaan. Informasi ini berbentuk laporan keuangan baik secara manual maupun secara online yang diperlukan oleh semua pihak.

e. SIA juga berfungsi sebagai suatu sistem pengendali keuangan agar tidak terjadi suatu kecurangan. Dengan sistem ini, keuangan perusahaan dapat dilacak dengan pasti karena sistem pertanggungjawaban yang detail. Fungsi ini dapat menjaga aset perusahaan dan mengurangi risiko untuk penggelapan aset oleh semua pihak terkait.

Jika perusahaan menerapkan sistem informasi akuntansi dengan baik, diharapkan semua laporan dapat disajikan tepat waktu. Jadi semua pihak internal maupun eksternal dapat mengambil keputusan dengan baik mengenai perkembangan perusahaan. Penggunaan SIA yang efektif akan membantu perkembangan perusahaan dalam jangka waktu yang panjang. Untuk mendukung sebuah usaha memiliki sebuah sistem informasi akuntansi yang baik tentunya butuh sistem pencatatan dan pelaporan yang baik pula. Jurnal software akuntansi online, sebagai salah satu platform penyedia layanan 
akuntansi online dapat memenuhi hal tersebut. Dengan memilih menggunakan Jurnal sebagai dukungan dalam mengelola pencatatan keuangan usaha, maka secara tidak langsung perusahaan akan memiliki sistem informasi akuntansi yang tertata dengan rapi dan kredibel yang dapat digunakan oleh pihak internal maupun eksternal perusahaan. SIA merupakan area pengkajian yang masih baru dan melibatkan beberapa area keahlian lain seperti ilmu akuntansi, konsep sistem, konsep manajemen, konsep pengendalian dan ilmu komputer

\subsection{Tujuan umum sistem informasi akuntansi}

Tujuan dan manfaat sistem informasi akuntansi atau biasa disebut dengan SIA memiliki peran yang penting bagi bisnis. Dimana sistem informasi akuntansi disini merupakan sistem informasi yang berbasis komputerisasi untuk mengolah data keuangan yang berhubungan dengan data transaksi dalam suatu siklus akuntansi dan menyajikannya dalam bentuk laporan keuangan kepada manajemen perusahaan. Dimana sistem sendiri merupakan seperangkat elemen yang saling bersamasama untuk mencapai tujuan tertentu yang mana sistem memiliki keterkaitan, integrasi dan tujuan yang sama serta memiliki beberapa sub sistem di dalamnya. Dengan definisi tersebut tak heran jika perusahaan yang menjalankan suatu bisnis pasti membutuhkan sistem informasi akuntansi untuk menunjang kinerja bisnisnya. Selain itu, tujuan dan manfaat sistem informasi akuntansi 
bagi perusahaan sendiri sangat besar untuk menunjang kinerja bisnis.

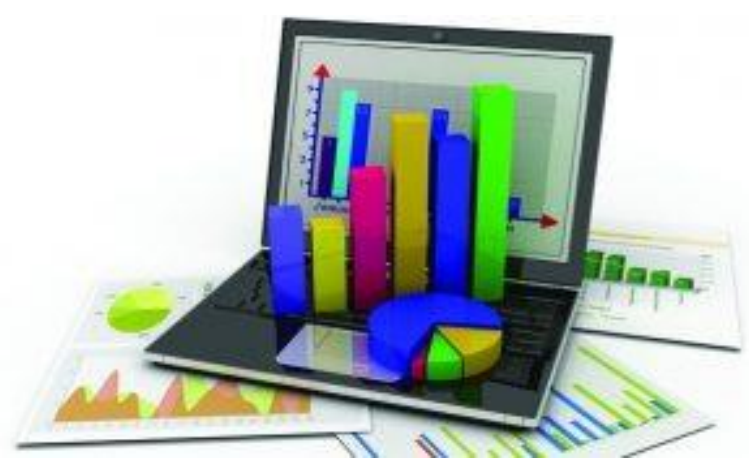

Tujuan dan Manfaat Sistem Informasi Akuntansi

Pada dasarnya tujuan dari sistem informasi akuntansi ini adalah untuk mengumpulkan, memproses dan melaporkan informasi yang berkaitan dengan aspek keuangan dari kegiatan bisnis perusahaan.

Berikut adalah uraian terkait tujuan dari sistem informasi akuntansi:

1. Mengumpulkan dan menyimpan data tentang aktivitas dan transaksi.

2. Memproses data menjadi informasi yang dapat digunakan dalam proses pengambilan keputusan terkait perencanaan dan pengendalian bisnis.

3. Melakukan kontrol secara tepat terhadap aset perusahaan.

4. Efisiensi biaya dan waktu terhadap kinerja keuangan 
5. Penyajian data keuangan yang sistematis dan akurat dalam periode akuntansi yang tepat.

Dari beberapa tujuan di atas dapat dikatakan sistem informasi akuntansi disini sangat membantu perusahaan dalam mengelola keuangannya dengan baik dan tepat. Selain menghemat waktu dan biaya, sistem informasi ini pun juga memberikan dampak untuk kinerja bisnis selanjutnya dengan sebuah pengambilan keputusan yang tepat. Sistem informasi akuntansi ini memiliki tiga sub sistem yang masing-masing memiliki peran sendiri-sendiri seperti sistem pemrosesan transaksi, sistem buku besar atau pelaporan keuangan, dan sistem penutupan dan pembalikkan. Dimana sub sistem tersebut dapat memproses berbagai transakis keuangan dan transaksi non keuangan yang secara langsung dapat memberikan pengaruh pada pemrosesan transaksi keuangan. Selanjutnya selain memiliki beberapa tujuan, sistem informasi akuntansi juga memiliki beberapa manfaat bagi suatu perusahaan.

\subsection{Mengapa Perlu Mempelajari SIA?}

Mahasiswa akuntansi sering mempertanyaan pertanyaan seperti tersebut di atas. Hal ini terjadi karena karakteristik dari ilmu ini berbeda dari beberapa matakuliah akuntansi yang lain. Dalam kebanyakan matakuliah akuntansi, mahasiswa ditempatkan sebagai pengguna informasi sehingga permasalahan yang harus dipecahkan sebatas bagaimana menjurnal transaksi, bagai mana melaporkan informasi (laporan keuangan) kepada pihak lain seperti manajer, pemegang saham, kreditor, pemerintah dan lain - lain, atau 
bagaimana mengaudit laporan keuangan tersebut. Namun jarang terlintas dalam benak mereka pertanyaan seperti dari mana informasi itu dihasilkan? Pertanyaan inilah yang menjadikan perlunya SIA dipelajari oleh mahasiswa akuntansi dan masuk dalam kurikulum akuntansi. Alasan lain mengapa perlu dipelajarinya SIA ini adalah perkembangan teknologi komputer yang sangat pesat sehingga berpengaruh terhadap proses penyediaan informasi akuntansi bagi proses manajemen. Penggunaan komputer ini menjadi sangat popular, banyak perusahaan yang mulai menginstalasi jaringan komputer untuk operasional usahanya. Sehingga matakuliah SIA yang menekankan pada peran teknologi komputer menjadi sangat penting untuk dipelajari oleh mahasiswa akuntansi.

\section{Berikut adalah uraian manfaat sistem informasi akuntansi bagi perusahaan:}

1. Menyediakan atau menyajikan informasi yang akurat dan tepat waktu sehingga perusahaan dapat melakukan aktivitas utama pada value chain secara efektif dan efisien.

2. Meningkatkan kualitas dan mengurangi biaya produksi produk atau jasa yang dihasilkan.

3. Meningkatkan efisiensi kinerja bisnis, baik itu pada bagian keuangan dan bagian lainnya.

4. Meningkatkan kemampuan dalam pengambilan keputusan.

5. Meningkatkan sharing knowledge

Dari manfaat di atas dapat dikatakan bahwa sistem informasi akuntansi ini berperan penting untuk suatu 
perusahaan. Dengan adanya sistem informasi akuntansi yang baik maka perusahaan dapat melakukan proses operasi maupun informasi dengan lebih efektif dan efisien karena adanya pengendalian yang mampu mengendalikan prosesproses tersebut sehingga dapat menghasilkan tujuan yang sesuai dengan yang diinginkan perusahaan. Selain itu, informasi akuntansi yang dihasilkan pada sistem tersebut dapat dipertanggung jawabkan untuk nantinya digunakan dalam mengambil sebuah keputusan mengenai keuangan perusahaan maupun digunakan oleh pihak eksternal perusahaan untuk berhubungan dengan kegiatan bisnis. Sehingga ketika perusahaan mampu menjalankan sistem informasi akuntansi dengan baik, maka manfaat dan tujuan di atas dapat dirasakan langsung dampak positifnya bagi perusahaan. Sebaliknya jika perusahaan tidak dapat menjalankan sistem informasi keuangan dengan baik maka akan menghambat proses bisnis dan mengakibatkan kegiatan bisnis tersebut tidak berjalan dengan lancar

\subsection{Hubungan SIA dengan SIM}

Dalam melaksanakan proses manajemen, seorang manajer memerlukan berbagai macam informasi yang dapat ia peroleh dari berbagai macam sumber baik dari dalam (internal) maupun luar organisasi (eksternal). Informasi tersebut dapat diperoleh dengan cara formal maupun informal. Informasi yang diperoleh manajer dari dalam perusahaan dan diperoleh dengan cara formal itulah yang informasi yang bersumber dari Sistem Informasi Manajemen. Manajer dapat memperoleh informasi mengenai produksi dari Sistem Informasi 
Produksi, informasi mengenai karyawannya dari Sistem Informasi SDM, dan sebagainya. Sistem Informasi Akuntansi juga bisa dikatakan merupakan bagian dari Sistem Informasi Manajemen, karena ia menghasilkan informasi akuntansi yang digunakan manajer dalam menjalankan tugasnya. Hal inilah yang selam ini dikenal sebagai bidang akuntansi manajemen. Namun perlu diingat bahwa informasi yang dihasilkan oleh proses akuntansi tidak semata ditujukan pada pihak manajemen karena pihak eksternalpun mempunyai hak untuk mendapat informasi keuangan mengenai suatu perusahaan tertentu. Hal inilah yang selama ini kita pelajari dalam akuntansi keuangan.

Hubungan Sistem Informasi Akuntansi dengan Sistem Informasi Manajemen (SIM) Menurut Nugroho Widjajanto (2001:21) :

"Sistem informasi manajemen adalah suatu sistem informasi yang bersifat enyeluruh, bertujuan untuk menyajikan berbagai informasi yang jauh lebih luas daripada informasi akuntansi yang bersifat histories".

SIM bertujuan untuk memberikan informasi pengambilan keputusan dan pengarah perhatian, baik dalam satuan keuangan atau bukan, juga bagi manajer. Jadi SIM dan SIA saling melengkapi dalam perusahaan. Manajemen perusahaan menjalankan bisnis perusahaan dengan menggunakan sistem informasi yang disebut dengan sistem informasi manajemen. Untuk memasarkan produk 
dan jasa yang dihasilkan perusahaan, manajemen menggunakan sistem informasi pemasaran. Sistem informasi ini menghasilkan informasi yang memungkinkan manajemen mengambil keputusan mengenai langganan yang harus dilayani, jenis barang dan jasa yang diperlukan oleh pelanggan, saat dan cara pengiriman barang kepada pelanggan. Sistem informasi akuntansi merupakan salah saru subsistem dalam sistem informasi manajemen.

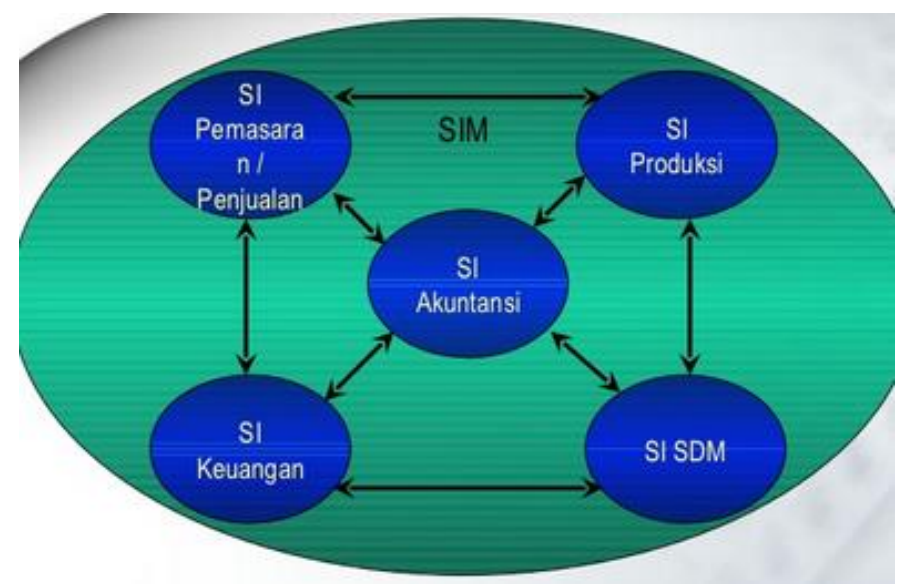

Gambar : Hubungan SIA dengan SIM

\subsection{Analisis sistem, desain sistem dan implementasi sistem}

\section{Analis Sistem}

Kegiatan analisis sistem adalah kegiatan untuk melihat yang sudahberjalan, melihat bagian mana yang bagus dan tidak bagus, dankemudian mendokumentasikan kebutuhan yang akan dipenuhi dalam sistem yang baru. Hal 
tersebut terlihat sederhana, namun sebenarnya tidak, banyak hambatan yang akan ditemui dalam proses tersebut. Hal pertama yang dilakukan dalam analisi sistem adalah melakukan pengumpulan data. Ada beberapa teknik pengumpulan data y a $\mathrm{n}$ sering dilakukan yaitu sebagai berikut:

1. Te kn ik W a w a n c a r a

P e n g u m i la $n$ d a t a d e $n g$ a $n$ $m$ e $n g g u n$ a $\mathrm{k} n$ $\mathrm{w}$ a $\mathrm{w}$ a $\mathrm{n}$ c a $\mathrm{r}$ a mempunyai beberapa keuntungan sebagai berikut :

a. Lebih mudah dalam menggali bagian sistem mana yang dianggap baik dan bagian mana yang dianggap kurang baik.

b. Jika ada bagian tertentu yang menurut Anda perlu untukdigali lebih dalam, Anda dapat langsung menanyakan kepadanarasumber.

c. Dapat menggali kebutuhan user secara lebih jelas.

d. Userdapat mengungkapkan kebutuhannya secara lebih jelas

1. Te kn i k O b s e r vas i.

Pengumpulan data dengan menggunakan observasi mempunyaikeuntungan yaitu :

a. Analis dapat melihat langsung bagaimana sistem I a maberjalan. 
b. Mampu menghasilkan gambaran lebih baik jika dibanding dengan teknik lainnya.

\section{Teknik Kuisioner}

Pengumpulan data dengan menggunakan kuisioner mempunyaikeuntungan yaitu:

a. Hasilnya lebih objektif, karena kuisioner dapat melakukan kepada banyak orang sekaligus

b. Waktunya lebih singkat

Sistem analis adalah orang yang menganalisis sistem dengan mempelajari masalah-masalah yang timbul dan menentukan kebutuhankebutuhan pemakai serta mengidentifikasikan pemecahan yang beralasan (lebih memahami aspek-aspek bisnisdan teknologi komputer). Nama lainnya: system designer, business analyst, systemconsultant, system engineer, software engineer, sistem analyst programmer, informationsystem engineer.

\section{Tugas dan tanggung jawab Sistem analis:}

a. Tanggung jawab analis sistem tidak hanya pada pembuatan program komputer saja, tetapi pada sistem secara keseluruhan.

b. Pengetahuan analis sistem harus luas, tidak hanya pada teknologi komputer, tetapi juga pada bidang aplikasi yang ditanganinya.

c. Pekerjaan analis sistem dalam pembuatan program terbatas pada pemecahan masalah secara garis besar. 
d. Pekerjaan analis sistem melibatkan hubungan banyak orang, tidak terbatas pada sesama analis sistem, programer tetapi juga pemakai sistem dan manajer.

\section{Programmer:}

a. Tanggung jawab pemrogram terbatas pada pembuatan program komputer.

b. Pengetahuan programer cukup terbatas pada teknologi komputer, sistem komputer, utilitas dan bahasa-bahasa program yang diperlukan.

c. Pekerjaan programer sifatnya teknis dan harus tepat dalam pembuatan instruksi-instruksi program. Pekerjaan programer tidak menyangkut hubungan dengan banyak orang, terbatas pada sesama pemrogram dan analis sistem yang mempersiapkan rancang bangun (spesifikasi) program.

d. Pengetahuan dan keahlian analis sistem. Analis sistem harus mempunyai pengetahuan yang luas dan keahlian yang khusus. Beberapa analis setuju bahwa pengetahuan-pengetahuan dan keahlian berikut sangatdiperlukan bagi seorang analis sistem yang baik.

\section{Pengetahuan dan keahlian analis sistem}

Analis sistem harus mempunyai pengetahuan yang luas dan keahlian yang khusus. Beberapa analis setuju bahwa pengetahuan-pengetahuan dan keahlian berikut sangat diperlukan bagi seorang analis sistem yang baik :

a. Pengetahuan dan keahlian tentang teknik pengolahan data, teknologi komputer dan pemograman komputer. 
b. Keahlian teknis yang harus dimiliki adalah termasuk keahlian dalam penggunaan alat dan teknik untuk pengembangan perangkat lunak aplikasi serta keahlian dalam menggunakan komputer.

c. Pengetahuan teknis yang harus dimiliki meliputi pengetahuan tentang perangkat keras, teknologi komunikasi data, bahasa-bahasa komputer, sistem operasi, utiliti, dan paket-paket perangkat lunak lainnya.

d. Pengetahuan tentang bisnis secara umum

Aplikasi bisnis merupakan aplikasi yang sekarang paling banyak diterapkan, maka analis sistem harus mempunyai pengetahuan tentang ini. Pengetahuan ini dibutuhkan supaya analis sistem dapat berkomunikasi dengan pemakai sistem. Pengetahuan tentang bisnis ini meliputi akuntansi keuangan, akuntansi biaya, akuntansi manajemen, sistem pengendalian manajemen, pemasaran produksi, manajemen personalia, keuangan, perilaku organisasi, kebijaksanaan perusahaan danaspek-aspek bisnis lainnya.

\section{Desain Sistem}

Desain atau perancangan dalam pembangunan

perangkatlunakm er up ak a n u p a y untuk mengontruksi s e bua h $\mathrm{s}$ i s $\mathrm{t}$ e $\mathrm{m}$ y a $\mathrm{n}$ g memberikan kepuasan (mungkin informal) akan spesifikasi kebutuhanfungsional, memenuhi target, memenuhi kebutuhan secara implisitatau eksplisit dari segi performansi 
maupun penggunaan sumber daya,kepuasan batasan pada proses desain dari segi biaya dinilai dari segi kepuasan pengguna perangkat lunak terhadap perangkat lunak yang digunakan

Langkah-langkah dalam membuat desain konseptual sistem :

a. mengevaluasi berbagai alternatif desain

b. membuat spesifikasi desain

c. membuat laporan desain konseptual sistem

Pertimbangan dan Berbagai Alternatif Desain

Analisis Sistem

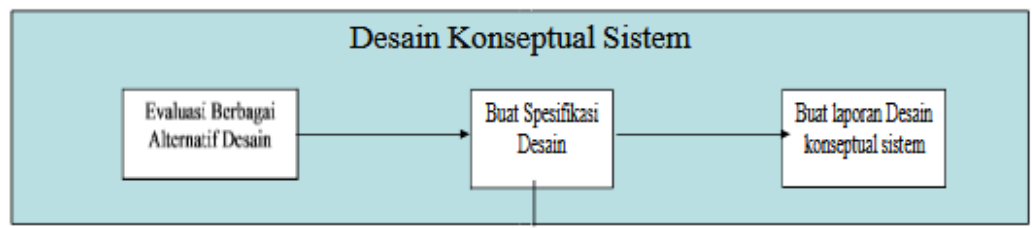

Desain Fisik

Implementasi

dan Perubahan

Operasi dan

Pemeliharaan

Standar yang digunakan untuk mengidentifikasi dan mengevaluasi alternatif desain adalah : 
- desain harus memenuhi tujuan organisasi dan sistem

- desain harus memenuhi kebutuhan para pemakai

- desain secara ekonomi layak atau tidak

- keuntungan dan kelemahan desain

Elemen - elemen untuk mengembangkan spesifikasi desain konseptual, adalah :

- Output

- Penyimpanan Data

- Input

- Prosedur dan Operasi Pemrosesan

Tujuan laporan desain konseptual sistem

- Memberi petunjuk pada aktivitas desain sistem

- Mengkomunikasikan kebutuhan pihak manajemen dan para pemakai

- Membantu komite pelaksana menilai kelayakan sistem

\section{DESAIN FISIK SISTEM}

- Membuat Desain Output

- Membuat File dan Database

- Mendesain Input

- Menulis Program Komputer

- Mengembangkan Prosedur

- Membangun Pengendalian ke dalam SIA yang baru

Kategori yang biasanya menghasilkan output 
- Laporan Terjadwal

- Laporan Analisis untuk tujuan khusus

- Laporan Pengecualian khusus

- Laporan Permintaan

DESAIN INPUT

1.Desain Formulir

2.Desain Layar Komputer

\section{LANGKAH-LANGKAH MENGEMBANGKAN SOFTWARE}

1. Analisis sistem dari siklus hidup pengembangan sistem

2. Desain konseptual sistem dapat diteruskan hingga ke awal desain fisik

3. Dilakukan pada saat desain sistem

4. Dilakukan pada saat implementasi sistem

5. Dilakukan selama desain sistem

6. Dilakukan selama implementasi sistem

7. Diselesaikan selama implementasi sistem dan perubahan sistem

8. Tahap operasi dan pemeliharaan

9. Tahap Operasi dan Pemeliharaan

\section{IMPLEMENTASI SISTEM}

Adalah Proses memasang hardware dan software serta membuat SIA jadi dan dapat berjalan.

Perencanaan Implementasi 
- Pekerjaan Implementasi

- Perkiraan tanggal penyelesaian

- Perkiraan biaya dan orang-orang yang bertanggungjawab untuk setiap pekerjaan

\section{DAMPAK PERKEMBANGAN TEKNOLOGI KOMPUTER PADA SIA}

Sebelum membahas mengenai dampak perkembangan teknologi komputer pada SIA perlu dipahami dulu konsep dan hubungan antara data dan informasi. Data diartikan sebagai kumpulan fakta-fakta dan merupakan bahan mentah dari informasi. Sebaliknya informasi merupakan hasil olahan data yang berguna dan relevan. Fungsi SIA dalam hal ini ialah menyediakan informasi akuntansi bagi manajemen untuk menjalankan tugasnya. Komputer muncul dan banyak digunakan dalam berbagai aktivitas perusahaan. Komputer tidak mengubah fungsi SIA sebagai penyedia informasi yang relevan bagi berbagai pihak yang berkepentingan, namun ia berpengaruh besar bagi SIA dalam proses menghasilkan suatu informasi dan dalam pengembangan SIA itu sendiri. Dalam bidang auditing, komputer juga mempengaruhi prosedur yang dilakukan auditor dalam menguji pengendalian internal perusahaan. Sedangkan dalam bidang akuntansi keuangan komputer telah memudahkan dan mempercepat pekerjaan akuntan dengan mengkomputerisasikan prosedur-prosedur pencatatan, pengklasifikasian, dan peringkasan data transaksi. Hal inilah yang dinamakan Electronic Data Processing (EDP).

EDP seringkali diidentikkan dengan SIA, namun perlu dicatat bahwa cakupan SIA lebih luas dari EDP. Aplikasi teknologi 
komputer bukanlah keharusan dalam SIA namun ia 'hanya' memberikan fasilitas kemudahan pada fungsi SIA dan pengembangannya. Ketika teknologi komputer diaplikasikan dalam SIA, maka istilah yang digunakan dalam hal ini adalah SIA berbasis komputer.

\subsection{Bagan alir}

Dokumentasi meliputi bentuk naratif, bagan alir (flowchart), diagram dan materi tertulis lainnya yang menjelaskan bagaimana sistem bekerja. Deskriptif naratif sistem: penjelasan tiap tahap mengenai komponen dan interaksi sistem Dalam bab ini akan dibahas mengenai:

1. Diagram arus data

2. Bagan alir (flowchart) dokumen

3. Bagan alir (flowchart) sistem

4. Bagan alir program

Diagram arus data (data flow diagram -DFD) mendeskripsikan arus data dalam sebuah organisasi untuk mendokumentasikan sistem yang sudah ada dan merencanakan sistem yang baru. Elemen-elemen dalam DFD :

1. Sumber dan tujuan data

2. Arus data

3. Proses tranformasi

4. Penyimpanan data

Sumber dan tujuan data dalam DFD mewakili suatu organisasi atau individu yang mengirim atau menerima data yang dihasilkan sistem. Arus data mewakili arus data antara pemrosesan, penyimpanan serta sumber dan tujuan data. Arus data dapat 
terdiri dari satu atau lebih bagian data. Proses mewakili transformasi data. Penyimpanan data adalah tempat penyimpan data baik secara permanen maupun temporer. DFD tidak memperlihatkan media penyimpanan secara fisik (seperti disk dan kertas) tetapi bersifat deskriptif.

Simbol untuk Pembuatan Bagan Alir Dokumen (Document Flowchart)

Sistem informasi akuntansi dapat dijelaskan dengan menggunakan bagan alir dokumen (Document Flowchart) digunakan simbolsimbol. Dalam bagan alir, arus dokumen digambarkan berjalan dari kiri ke kanan dan dari atas ke bawah. Arah perjalanan dokumen ini dapat diikuti dengan melihat nomor dalam simbol penghubung pada alaman yang sama (on-page connector) atau nomor dalam simbol enghubung pada halaman yang berbeda (offpage connector). Penggunaan bagan alir lebih bermanfaat dibandingkan dengan uraian tertulis dalam menggambarkan suatu sistem. Manfaat tersebut adalah sebagai berikut :

1. Gambaran sistem secara menyeluruh lebih mudah diperoleh dengan menggunakan bagan alir.

2. Perubahan sistem lebih mudah digambarkan dengan menggunakan bagan alir.

3. Kelemahan-kelemahan dalam sistem dan identifikasi bidang-bidang yang memerlukan perbaikan lebih mudah ditemukan dengan bagan alir.

4. Dokumentasi sistem akuntansi dilakukan dengan menggunakan bagan alir. 


\begin{tabular}{|c|c|}
\hline Simbol & Keterangan \\
\hline & $\begin{array}{c}\text { Simbol Arus/ Flow } \\
\text { Untuk menxatakan jalannxa anus suatuproses. }\end{array}$ \\
\hline & $\begin{array}{l}\text { Simbol Communication Link } \\
\text { Untuk menxatakan bahwa adanxa transisi suaty } \\
\text { data/informasi dan satu lokasi ke lokasi lainnya. }\end{array}$ \\
\hline & $\begin{array}{l}\text { Simbol Connector } \\
\text { Untuk menyatakan sambungan dani satu proses ke } \\
\text { proses lainnya dalam halaman/ lembar yang sama. }\end{array}$ \\
\hline & $\begin{array}{l}\text { Simbol Offline Connector } \\
\text { Untulk menyatakan sambungan dari satu proses ke proses } \\
\text { lainnya dalam halaman lembar yang berbeda. }\end{array}$ \\
\hline & $\begin{array}{l}\text { Simbol Process } \\
\text { Simbol yangmenuryukkan pengolahan yang dilakukan } \\
\text { oleh computer. }\end{array}$ \\
\hline
\end{tabular}




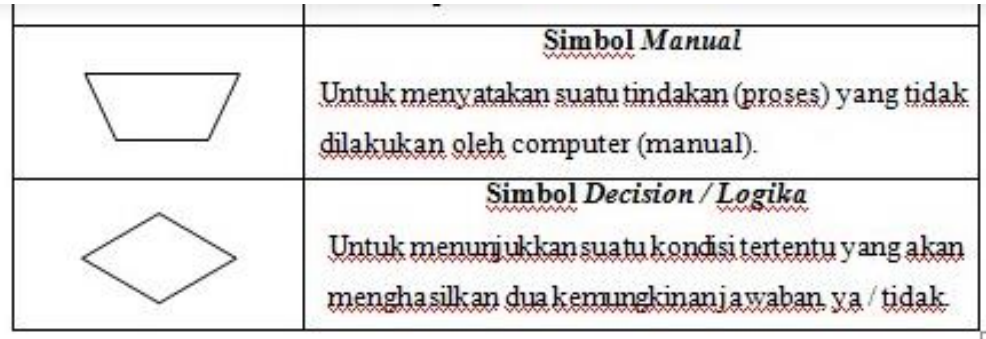

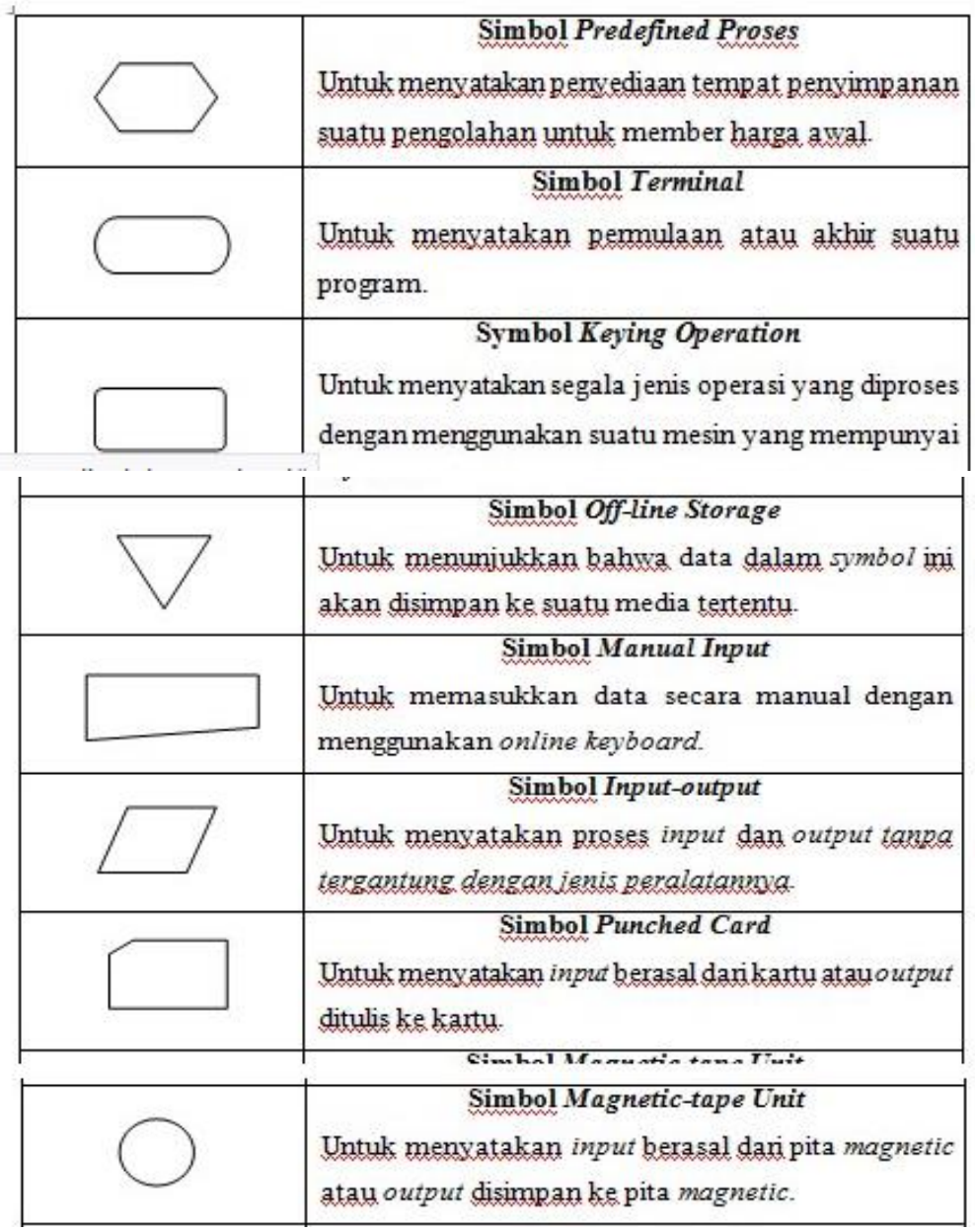




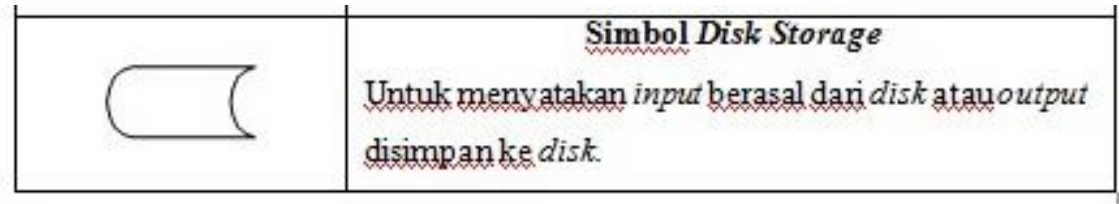

\begin{tabular}{|c|l|}
\hline & \multicolumn{1}{c|}{$\begin{array}{c}\text { Simbol Document } \\
\text { Dokumen dapat dibuat dengan tangan dan untuk } \\
\text { mencetak laporan ke printer. }\end{array}$} \\
\hline & $\begin{array}{l}\text { Simbol Display } \\
\text { Untuk menxatakan peralatan output yang digunakan } \\
\text { berupa layar (video, komputer). }\end{array}$ \\
\hline
\end{tabular}




\section{BAGIAN 2}

\section{SISTEM PENGENDALIAN INTERN (SPI)}

\section{TUJUAN INSTRUKSIONAL}

Mampu Menjelaskan dan memahami Sistem pengendalian intern, merancang SPI sesuai dengan kondisi internal perusahaan

\section{SUB BAGIAN}

\subsection{Pengertian, unsur-unsur, tujuan dan lingkungan SPI}

\section{Pengertian sistem pengendalian intern}

Sistem Pengendalian Internal adalah suatu sistem usaha atau sistem sosial yang dilakukan perusahaan yang terdiri dari struktur organisasi, metode dan ukuran-ukuran untuk menjaga dan mengarahkan jalan perusahaan agar bergerak sesuai dengan tujuan dan program perusahaan dan mendorong efisiensi serta dipatuhinya kebijakan manajemen. Sistem Pengendalian Internal yang handal dan efektif dapat memberikan informasi yang tepat bagi manajer maupun dewan direksi yang bagus untuk mengambil keputusan maupun kebijakan yang tepat untuk pencapaian tujuan perusahaan yang lebih efektif pula.

Sistem Pengendalian Internal berfungsi sebagai pengatur sumberdaya yang telah ada untuk dapat difungsikan secara maksimal guna memperoleh pengembalian (gains) yang maksimal 
pula dengan pendekatan perancangan yang menggunakan asas Cost-Benefit.

\subsection{Ciri-ciri Sistem Pengendalian Intern yang Memadai}

Suatu sistem pengendalian intern yang memadai adalah jika karyawan perusahaan tidak melakukan kesalahan baik secara administrative maupun akuntansi. Menurut Mulyadi (2001:164), unsur pokok pengendalian intern adalah:

1. Struktur organisasi yang memisahkan tanggung jawab fungsional secara tegas.

2. Untuk menciptakan pengendalian intern dalam perusah aan, perlu dibentuk struktur organisasi yang memisahkan tanggung jawab fungsional secara tegas, yang didasarkan pada prinsip-prinsip berikut ini :

3. Fungsi-fungsi operasi dan penyimpanan harus dipisahkan dari fungsi akuntansi.

4. Suatu fungsi tidak boleh diberi tanggung jawab penuh untuk melaksanakan seluruh tahap suatu transaksi.

5. Sistem wewenang dan prosedur pencatatan yang memberikan perlindungan yang cukup terhadap kekayaan, utang, pendapatan dan biaya.

Dalam suatu perusahaan, unsur yang perlu dirancang dalam menciptakan pengendalian intern adalah sistem wewenang (otorisasi) dan prosedur pencatatan dikarenakan dalam organisasi, setiap transaksi hanya terjadi atas dasar otorisasi dari 
pejabat yang memiliki wewenang untuk menyetujui terjadinya transaksi tersebut. Oleh karena itu dalam organisasi harus dibuat sistem yang mengatur pembagian wewenang untuk otorisasi atas terlaksananya setiap transaksi.

\section{Sistem Pengendalian Intern dan Risiko}

Sistem pengendalian intern diperlukan dalam perancangan berbagai sistem informasi akuntansi dan dimasukkan sebagai unsur yang melekat dalam sistem informasi akuntansi. Sistem pengendalian intern menekankan tujuan yang hendak dicapai, dan bukan pada unsur-unsur yang membentuk sistem tersebut. Dengan demikian, pengendalian intern berlaku baik dalam perusahaan yang mengolah informasinya secara manual, dengan mesin pembukuan, maupun dengan komputer.

Organisasi atau perusahaan dalam menjalankan kegiatan operasionalnya akan menghadapi berbagai permasalahan. Permasalahan-permasalahan yang timbul memerlukan sistem pengendalian intern untuk mendukung kegiatan operasional perusahaan agar dapat berjalan efektif dan efisien sesuai dengan kebijakan yang telah ditetapkan.

\section{Praktik yang sehat dalam melaksanakan tugas dan fungsi setiap unit organisasi.}

Pembagian tanggung jawab dan sistem wewenang serta prosedur pencatatan yang telah ditetapkan tidak akan terlaksana 
dengan baik jika tidak diciptakan cara-cara untuk menjamin praktik yang sehat dalam pelaksanaannya.

Adapun cara-cara yang umumnya ditempuh oleh perusahaan antara lain :

a. Penggunaan formulir bernomor urut tercetak yang pemakaiannya harus dipertanggungjawabkan oleh yang berwenang.

b. Pemeriksaan mendadak (surprised audit)dilaksanakan tanpa pemberitahuan lebih dahulu kepada pihak yang akan diaudit, dengan jadwal yang tidak teratur. Hal ini akan mendorong karyawan melaksakan tugasnya sesuai dengan aturan yang telah ditetapkan.

c. Setiap transaksi tidak boleh dilaksanakan dari awal sampai akhir oleh satu orang atau satu unit organisasi tanpa ada campur tangan dari orang atau unit organisasi lain.

d. Perputaran jabatan (job rotation). Jika diadakan secara rutin akan dapat menjaga independensi pejabat dalam melaksanakan tugasnya, sehingga dapat mengurangi kemungkinan terjadinya kolusi.

e. Wajib cuti sementara. Selama cuti, jabatan karyawan yang bersangkutan digantikan sementara dengan karyawan lain, sehingga jika terjadi kecurangan dalam departemen yang bersangkutan, diharapkan dapat diungkap oleh karyawan yang menggantikan untuk sementara tersebut.

f. Pencocokkan jumlah fisik kekayaan dengan catatannya secara periodik.

g. Pembentukkan unit organisasi yang bertugas untuk mengecek efektivitas unsur-unsur sistem pengendalian intern lainnya. 
h. Karyawan yang mutunya sesuai dengan tanggung jawabnya. Bagaimanapun baiknya struktur organisasi, sistem otorisasi dan prosedur pencatatan, serta berbagai cara yang diciptakan untuk mendorong praktik yang sehat, semuanya sangat tergantung kepada manusia yang melaksanakannya. Unsur mutu karyawan merupakan unsur pengendalian intern yang paling penting. Jika perusahaan memiliki karyawan yang kompeten dan jujur, unsur pengendalian yang lain dapat dikurangi sampai batas yang minimum, dan perusahaan tetap mampu menghasilkan pertanggungjawaban keuangan yang dapat diandalkan.

\subsection{Risiko yang Berkaitan dengan Sistem}

Risiko merupakan ancaman terhadap aset dan kualitas informasi perusahaan akibat terabainya atau tidak memadainya pengendalian. Menurut Wilkinson (1993:199), ada beberapa risiko yang berkaitan dengan sistem yang dihadapi perusahaan adalah :

1. Kesalahan yang tidak disengaja.

2. Kesalahan yang disengaja.

3. Kehilangan aset secara tidak sengaja.

4. Pencurian aset.

5. Pelanggaran keamanan.

6. Tindak kekerasan dan bencana alam.

Tujuan penerapan SPI dalam perusahaan adalah untuk menghindari adanya penyimpangan dari prosedur, laporan keuangan yang dihasilkan perusahaan dapat dipercaya dan kegiatan perusahaan sejalan dengan hukum dan peraturan yang 
berlaku. Hal ini menunjukkan bahwa perusahaan terutama manajemen berusaha untuk menghindari resiko dari adanya penerapan suatu sistem.

Sistem informasi akuntansi sebagai sistem yang terbuka tidak bisa dijamin sebagai suatu sistem yangbebas dari kesalahan maupun kecurangan. Pengendalian intern yang baik merupakan cara bagisuatu sistem untuk melindungi diri dari tindakan-tindakan yang merugikan. Dalam arti sempit, pengendalian internhanya dibatasi pada kegiatan pengecekan, penjumlahan, baik penjumlahan mendatar maupun penjumlahan menurun.

Pengendalian intern secara luas, diantaranya ;

Batasan pengendalian intern, sebagai suatu sistem pengendalian yang meliputi struktur organisasi beserta semua metode dan ukuran yang diterapkan dalam perusahaan, dengan tujuan untuk :

1. mengamankan aktiva perusahaan

2. mengecek kecermatan dan ketelitian data akuntansi

3. meningkatkan efisiensi

4. mendorong agar kebijakan manajemen dipatuhi oleh segenap jajaran organisasi

Ringkasnya bahwa pengendalian intern tidak hanya meliputii pekerjaan pengecekan tetapi juga meliputi semua sistem kerja yang terjadi dalam perusahaan dalam upaya mencapai tujuan perusahaan. 
Dari definisi pengendalian intern yang dikemukakan tersebut diatas dapat ditemukan beberapa konsep dasar berikut :

- Pengendalian intern merupakan suatu proses untuk mencapai tujuan tertentu, atau merupakan suatu rangkaian tindakan yang menjadi bagian yang tidak terpisahkan.

- Pengendalian intern bukan hanya terdiri dari pedoman, kebijakan, formulir, namun dijalankan oleh orang dari setiap jenjang organisasi, yang mencakup dewan komisaris, manajemen dan personil lain.

- Pengendalian intern diharapkan mampu memberikPengendalian intern diharapkan mampu memberikan keyakinan memadai, bukan keyakinan mutlak bagi manajemen dan dewan komisaris entitas. Keterbatasan yang melekat dalam semua sistem pengendalian intern dan pertimbangan manfaat serta pengorbanan dalam pencapaian tujuan pengendalian, menyebabkan pengendalian intern tidak dapat memberikan keyakinan mutlak.

- Pengendalian intern ditujukan untuk mencapai tujuan yang saling berkaitan yaitu pelaporan keuangan, kepatuhan dan operasi.

Sistem pengendaliaan intern meliputi struktur organisasi, metode, dan ukuran yang diorganisasikan untuk menjaga kekayaan organisasi, mengecek ketelitian dan kehandalan data akuntansi, mendorong efisiensi untuk dipatuhinya kebijakan manajemen. Sistem pengendalian 
intern merupakan kebijakan, praktik, dan prosedur yang digunakan organisasi untuk mencapai empat tujuan utama :

1. Untuk menjaga aktiva perusahaan

2. Untuk memastikan akurasi dan dapat diandalkan catatan dan informasi akuntansi

3. Untuk mempromosikan efisiensi operasi perusahaan

4. Untuk mengukur kesesuaian kebijakan dan prosedur yang telah ditetapkan oleh manajemen.

Berangkat dari tujuan diatas, maka sistem pengendalian intern dapat dikelompokkan menjadi dua bagian, yaitu :

a. Pengendalian intern akuntansi (internal accounting control), Pengendalian intern akuntansi meliputi persetujuan, pemisahan antara fungsi operasi, penyimpanan dan pencatatan serta pengawasan fisik atas kekayaan.

b. Pengendalian intern administrasi (internal administratife control), Pengendalian intern administrasi meliputi peningkatan efisiensi usaha, dan mendorong dipatuhinya kebijakan pimpinan, misalnya analisis statistik, studi waktu dan gerak, program pelatihan, dan pengendalian mutu kegiatan perusahaan .

\section{Karakteristik sistem pengendalian intern}

Kehandalan sistem pengendalian intern harus dilandasi dengan karakteristik dari sistem tersebut yaitu : 
- Adanya pendelegasian wewenang kepada petugas tertentu untuk menyetujui transaksi dan penetapan tugas, pengecekan kepada petugas yang lain untuk mengetahui bahwa transaksi telah disetujui oleh petugas yang berwenang.

- Adanya

penyele nggaraan akuntansi sedemikian rupa sehingga mudah di cek.

- Adanya pendelegasian secara fisik yang tepat, termasuk penjagaan berganda terhadap aktiva yang dimiliki.

- Adanya perifikasi secara periodik terhadap eksistensi aktiva yang dicatat.

- Memiliki pegawai yang cakap, mempunyai kemampuan dan latihan yang cukup, sesuai dengan tingkat pertanggungjawabannya.

Adanya pemisahan fungsi penyimpanan aktiva dari fungsi pencatatan, dan dari pelaksanaan transaksi yang bersangkutan.

\section{Penanggungjawab SPI}

Secara struktural pihak-pihak yang bertanggung jawab dan terlibat langsung dalam perancangan dan pengawasan Sistem Pengendalian Internal meliputi :

a. Chief Executive Officer (CEO)

b. Chief Financial Officer (CFO)

c. Controller / Director Of Accounting \& Financial

d. Internal Audit Comitee 


\subsection{Pendekatan perancangan SPI}

Bentuk-bentuk Pengendalian Akuntansi

\section{a. Pengendalian Umum}

Pengendalian umum adalah suatu pengendalian terhadap semua aktivitas pemrosesan data dengan komputer, hal ini meliputi pemisahan tanggung jawab dan fungsi pengolahan data.

Pengendalian umum merupakan standart dan panduan yang digunakan oleh karyawan untuk melakukan fungsinya. Unsur pengendalian umum ini meliputi: Organisasi, prosedur dan standar untuk perubahan program, pengembangan sistem dan pengoperasian fasilitas pengolahan data.

Yang termasuk dalam pengendalian umum diantranya :

a. Pengendalian organisasi dan operasi

b. Pengendalian dalam pengembangan sistem

c. Pengendalian atas Dokumentasi

d. Pengendalian perangkat keras, perangkat lunak sistem operasi dan perangkat lunak sistem lainnya

e. Pengendalian penggunaan komputer, fasilitas dan datanya

\section{b. Pengendalian Aplikasi}

Pengendalian aplikasi adalah suatu pengendalian yang mencakup semua, pengawasan transaksi dan penggunaan program- program aplikasi dikomputer. Untuk menjaga agar setiap transaksi mendapat otorisasi serta dicatat, diklasifikasikan, diproses, dan dilaporkan dengan benar. 
Tujuan dari pengendalian aplikasi adalah untuk mencegah atau mendeteksi adanya penyelewengan akan aplikasi program yang diterapkan pada sistem perusahaan.

\section{c. Pengendalian Administrasi}

\section{Pengertian}

Pengendalian administrasi (administrative control) adalah suatu pengendalian yang termasuk dalam unsur pengendalian internal pada poin 3 dan 4 yang meliputi rencana, prosedur dan pencatatan yang mendorong efisiensi dan ditaatinya kebijakan manajemen yang ditetapkan.

Pengendalian administrasi dibuat untuk mendorong dilakukannya efisiensi dan mendorong dipatuhinya kebijakkan manajemen (dikerjakan setelah adanya pengendalian akuntansi). Pengendalian administratif mendukung pengendalian akuntansi yang berorientasi pada manajemen.

Contoh : pemeriksaan laporan untuk mencari penyimpangan yang ada, untuk kemudian diambil tindakan.

Yang termasuk dalam pengendalian administratif, yaitu:

a. Pengendalian perencanaan, yang terdiri dari anggaran penjualan (sales budget), perencanaan induk (master plan), perennaan jagajaga (contingency plan), peramalan arus kas (cash flow forecast) dan pengendalian perediaan (inventory control)

b. Pengendalian personil, yang terdiri dari recruitment, pelatihan, evaluasi pekerjaan, administrasi gaji, promosi dan transfer 
c. Pengendalian standar operasi, yang terdiri dari standar yang harus dikerjakan dan system untuk melaporkan penyimpangan

\section{Tujuan}

Pengendalian administratif memiliki tujuan utama:

1) Meningkatkan efisiensi operasi kegiatan

2) Mendorong ditaatinya kebijaksanaan-kebijaksanaan perusahaan

\section{Bentuk-bentuk Pengendalian Administrasi}

\section{a. Pengendalian umpan balik}

Pengendalian umpan balik adalah suatu proses mengukur keluaran (output) dari sistem yang membandingkan dengan suatu terstandar tertentu. Bilamana terjadi perbedaan-perbedaan atau penyimpangan maka akan dikoreksi untuk memperbaiki masukan (input) sistem selanjutnya. Pada sistem ini keluaran (output) tidak ikut andil dalam aksi pengendalian. Di sini kinerja kontroler tidak bisa dipengaruhi oleh input atau masukan referensi.

\section{b. Pengendalian umpan maju}

Pengendalian umpan maju atau disebut juga dengan istilah umpan balik positif adalah mendorong proses dari sistem supaya menghasilkan hasil balik yang positif. Sistem pengendalian umpan maju merupakan perkembangan dari sistem umpan balik. Supaya suatu keluaran (output) dapat menghasilkan umpan balik yang positif maka pengendalian tidak boleh diukur dari keluarannya tetapi diukur dan dikendalikan dari prosesnya. Dan selama proses terjadi didalam sistem maka selalu dilakukan pengamatan dan cepat-cepat diatasi bila mulai terjadi 
penyimpangan, sebelum terlanjur fatal pada keluarannya. Pengendalian jenis ini adalah suatu sistem pengaturan dimana sistem keluaran pengendalian ikut andil dalam aksi kendali.

\subsection{Pengendalian Intern Akuntansi dalam PDE Lingkungan pengendalian}

Terdapat tujuh faktor penting dalam lingkungan pengendalian, yaitu:

a. Komitmen kepada integritas dan nilai etika.

Perusahaan dapat menetapkan integritas sebagai sebuah prinsip dasar perusahaan, secara pribadi dan aktif melakukan sosialisasi sekaligus mempraktikannya.

b. Filosofi dan gaya operasi manajemen Komponen utama lingkaran pengawasan yaitu filosofi dan gaya operasi manajemen. Jika manajemen tidak terlalu memberikan perhatian terhadap pengendalian intern dan perilaku etik, maka karyawan perusahaan tidak dapat diharapkan dapat mencapai tujuan pengawasan secara efektif.

c. Struktur organisasi

Struktur organisasi suatu perusahaan menetapkan garis wewenang dan tanggung jawab, dan memberikan kerangka menyeluruh untuk perencanaan, pengarahan, dan pengendalian operasi.

d. Komite audit

Komite ini bertanggung jawab untuk mengatasi struktur pengawasan intern perusahaan, proses 
pelaporan keuangan, dan ketaatan terhadap hukum, peraturan, dan standar yang berlaku. Tugasnya berkaitan dengan auditor eksternal dan internal.

e. Metode penetapan wewenang dan tanggung jawab.

Wewenang dan tanggung jawab biasanya diatur dan ditetapkan dalam deskripsi jabatan (Job Description), pelatihan karyawan, rencana kegiatan, jadwal, dan anggaran. Biasanya buku pedoman digunakan sebagai pedoman prosedur dan kebijakan tertulis dalam berbagai organisasi.

f. Praktik dan kebijakan tentang sumber daya manusia.

Kebijakan dan praktik yang berkaitan dengan pengangkatan, pelatihan, pemberian gaji, dan promosi memiliki pengaruh yang penting terhadap kemampuan organisasi meminimalkan resiko pengawasan intern.

g. Pengaruh eksternal.

Pengaruh eksternal mencakup peraturan dan ketentuan yang dikeluarkan oleh pasar modal, badan penyusun standar akuntansi, dan BAPEPAM.

\section{Aktivitas Pengendalian}

Aktivitas pengendalian merupakan kebijakan dan aturan yang memberikan jaminan yang cukup bahwa tujuan pengendalian manajemen telah dicapai. Yang umumnya dapat dibagi atas lima bagian, yaitu: 
a. Otorisasi yang tepat terhadap aktifitas dan transaksi.

Otorisasi didokumentasikan dengan menandatangani, member paraf, atau mencantumkan kode otorisasi pada dokumen atau catatan yang mewakili transaksi.

b. Pemisahan tugas

Pengendalian yang baik menghendaki tidak adanya seorang karyawan yang terlalu banyak diberi tanggung jawab atau tugas. Seorang karyawan mugkin saja berada dalam posisi untuk melaksanakan kecurangan, menyembunyikan kecurangan dan kesalahan.

c. Perancangan dan penggunaan dokumen dan catatan yang memadai Perancangan dan penggunaan dokumen serta catatan yang tepat akan menjamin akurasi dan kelengkapan seluruh data yang relevan tentang transaksi. Dokumen yang mengawali sebuah transaksi harus berisi ruang untuk mencantumkan otorisasi.

d. Perlindungan yang memadai terhadap akses dan penggunaan aktiva dan catatan Untuk melindungi aktiva dari pencurian atau penggunaan yang tidak sah bisa dilakukan cara seperti pemisahan fungsi yang efektif, pembatasan akses ke fasilitas dan ke ruang penyimpanan, melindungi catatan dan dokumen dengan menggunakan kotak penyimpanan tahan api, serta adanya filing cabinet dan ruangan harus selalu terkunci.

e. Pengecekan independen terhadap kinerja.

Pengecekan internal harus independen, karena ini biasanya lebih efektif dilaksanakan oleh seseorang yang tidak terkait dengan kegiatan perusahaan.

f. Perhitungan Resiko 
Organisasi harus menyadari dan waspada terhadap berbagai resiko yang dihadapinya. Akuntan dapat mengevaluasi struktur pengendalian intern dengan menggunakan strategi perhitungan resiko, diantaranya: identifikasi ancaman, estimasi kerugian, identifikasi pengendalian, estimasi manfaat dan pengorbanan, serta menentukan efektivitas manfaat pengorbanan.

g. Informasi dan Komunikasi

Sistem informasi yang relevan terhadap tujuan pelaporan keuangan terdiri dari metode dan catatan yang ditetapkan untuk mencatat, mengolah, mengikhtisarkan, dan melaporkan transaksi suatu entitas. Komunikasi mencakup pemberian pemahaman peran individual dan tanggung jawab yang berkaitan dengan pengendalian intern atas pelaporan keuangan.

h. Pemantauan Kinerja

Pemantauan kinerja merupakan hal yang penting dalam pengawasan. Metode pokok dalam melakukan pemantauan kerja, yaitu: supervise yang mencakup pelatihan dan asistensi karyawan, pemantauan kinerja karyawan, koreksi kesalahan, dan penjagaan aktiva dengan cara memantau karyawan yang memiliki akses ke aktiva tersebut, pelaporan pertanggungjawaban dan internal auditing yang memberikan suatu penilaian terhadap efektivitas pengawasan intern.

Pengendalian Intern Sistem Informasi Akuntansi Berbasis Komputer 
Elemen pengendalian intern yang ada pada sistem informasi berbasis komputer hampir sama dengan sistem manual. Beberapa hal berikut menjadikan adanya penekanan yang berbeda pada pengendalian intern untuk kedua jenis sistem itu:

1. Sistem informasi terkomputerisasi lebih luas lingkup pengendaliannya karena sebagianbesar proses tidak terlihat secara nyata oleh indra manusia.

2. Sedikitnya bukti berupa dokumen. Diperlukan desain sistem yang mampu meninggalkan jejak untuk keperluan pengauditan (audit trial).

3. Pengendalian harus diintegrasikan kedalam rancangan sistem sebagai salah satu elemen yang mendukung kekuatan desain sistem tersebut.

4. Diperlukan prosedur dokumentasi yang baik sehingga mampu merekam seluruh proses sekaligus pengmbangan sistem itu sendiri. Prosedur back-up termasuk dalam hal ini.

5. Perlu dilakukan sentralisasi informasi utnuk memudahkan pengendalian.

6. Memungkinkan pengendalian intern melalui programprogram komputer.

7. Pengendalian pada salah satu fungsi mungkin dapat melemahkan pengendalian padafungsi yang lain.

Elemen-elemen pokok pengendalian intern sistem informasi berbasis komuter dikelompokkan sebagai berikut:

1. Pengendalian Manajemen (Management Control)

Pengendalian manajemen yang diperlukan oleh sebuah sistem informasi meliputi : 
a. Pengendalian terhadap rencana induk sistem informasi, apakah desain sistem informasi telah memenuhi garis besar dan spesifikasi yang dimaksud dalam rencana induk.

b. Pemisahan fungsi, berbeda sedikit dengan sistem manual. Fungsi yang perlu dipisahkan adalah:

1. Perancangan dan penyusunan program sistem

2. Operasi pengolahan data

3. Dokumentasi program dan kepustakaan

4. Seleksi dan pelatihan karyawan

5. Perlu adanya buku petunjuk operasional sistem dan prosedur yang ada dalam sistem tersebut.

6. Pengendalian anggaran.

2. Pengendalian Terhadap Pengembangan Sistem.

Penerapan sistem informasi akuntansi berbasis komputer merupakan investasi yang besar, demikian pula untuk pengembangan selanjutnya. Perusahaan perlu melakukan pengendalian intern dalam mengembangkan sistem informasinya, jenis pengendalian yang diterapkan untuk hal ini adalah:

a. Pengendalian terhadap dokumentasi sistem. Pengendalian ini diperlukan karena dokumentasi sistem merupakan alat komunikasi antara perancang sistem dengan users.

b. Sistem dan pengembangan sistem yang tidak didokumentasikan dengan baik akan menambah biaya pengembangan karena harus mencari 
informasi mengenai detail sistem ke pihak perancang terdahulu.

c. Pengendalian terhadap pengubahan program. Perlu otorisasi seperti halnya pada pengendalian siklus pengembangan sistem.

\section{Pengendalian Akses (Access Control)}

Pengendalian akses merupakan kunci dari sistem informasi berbasis komputer. Penerapan berbagai teknik password bertingkat untuk mengendalikan akses setiap personil merupakan teknik yang paling banyak digunakan. Pengendalian akses mencakup lingkup berikut:

a. Pengendalian akses terhadap perangkat keras. Tidak setiap karyawan memiliki wewenang untuk keruangan di mana komputer induk dan media penyimpanan diletakkan. Selain itu perlu pulaprosedur pengamanan perangkat keras dari berbagai bencana dan kecelakaan yang disebabkan oleh hal lain.

b. Pengendalian akses terhadap perangkat lunak.

c. Pengendalian terhadap dokumentasi program.

Akses terhadap program ini hendaknya dilindungi melalui otorisasi dari pihak tertentu. Dengan memiliki dokumentasi program maka sangat memungkinkan seseorang memodifikasi program untuk kepentingan pribadi.

d. Pengendalian terhadap program dan file-file data. Pengendalian ini mutlak diperlukan karena sangat banyak data yang dihasilkan dari sebuah sistem 
informasi yang bersifat rahasia yang perlu dilindungi dari pihak -pihak tertentu. 


\section{BAGIAN 3}

KONSEP DASAR UNSUR-UNSUR SISTEM AKUNTANSI

POKOK PADA PERUSAHAAN

\section{TUJUAN INSTRUKSIONAL UMUM :}

Mampu menjelaskan dan memahami konsep dasar dan unsurunsur sistem akuntansi pokok pada perusahaan

\section{SUB BAGIAN :}

\subsection{Konsep dasar formulir}

\section{Formulir atau Dokumen}

Pengertian Formulir atau Dokumen, adalah :

Menurut Mulyadi (2001:75) "Formulir adalah secarik kertas yang memiliki ruang untuk diisi".

Faktur penjualan tunai merupakan contoh formulir, yang berupa secarik kertas yang akan diisi dengan informasi tanggal penjualan, nama wiraniaga dengan kodenya, nomor urut, nama barang dan kodenya, kuantitas, harga satuan, harga total setiap barang, harga total semua barang, dan tanda tangan wiraniaga.

Manfaat Formulir atau Dokumen Menurut Bodnar dan Hopwood (2003:30), formulir dalam perusahaan bermanfaat untuk : 
1. Menetapkan tanggung jawab timbulnya transaksi bisnis perusahaan.

2. Dalam suatu organisasi, setiap transaksi terjadi karena adanya otorisasi dari pejabat yang memiliki wewenang untuk melaksanakan transaksi tersebut. Pelaksanaan wewenang tersebut harus dipertanggungjawabkan dalam bentuk tertulis dengan menggunakan formulir.

3. Merekam data transaksi bisnis perusahaan. Semua data yang diperlukan untuk identifikasi transaksi direkam pertama kali dalam formulir.

4. Mengurangi kemungkinan kesalahan dengan cara menyatakan semua kejadian dalam bentuk tulisan. Semua perintah pelaksanaan suatu transaksi perlu ditulis dalam suatu formulir untuk mengurangi kemungkinan kesalahan, karena penyampaian secara lisan kemungkinan terjadinya kesalahan adalah besar.

5. Menyampaikan informasi pokok dari orang satu ke orang lain di dalam organisasi yang sama atau ke organisasi lain.

6. Formulir berfungsi pula sebagai sarana untuk menyampaikan informasi secara intern organisasi atau antar organisasi.

\section{Golongan Formulir Menurut Sumbernya}

Menurut sumbernya, formulir dapat dibedakan menjadi 3 golongan (Bodnar dan hopwood,2003:50):

1. Formulir yang dibuat dan disimpan dalam perusahaan. Formulir ini dibuat dalam perusahaan, digunakan secara intern, dan kemudian disimpan dalam perusahaan. Contoh 
formulir ini adalah : kartu jam kerja, surat permintaan pembelian, dan lain-lain.

2. Formulir yang dibuat dan dikirimkan kepada pihak luar perusahaan.

Formulir ini dibuat dalam perusahaan dan digunakan untuk menyampaikan informasi kepada pihak luar perusahaan. Contoh formulir ini adalah : faktur penjualan tunai, faktur penjualan kredit, surat order pembelian, dan lain-lain.

3. Formulir yang diterima dari pihak luar perusahaan.

Formulir ini diterima dari pihak luar sebagai akibat dari transaksi bisnis antara perusahaan dengan pihak luar tersebut. Contoh golongan formulir ini adalah : faktur pembelian, surat order dari pembeli, rekening koran (bank statement).

\section{Prinsip Dasar yang Melandasi Perancangan Formulir atau Dokumen}

Dalam merancang suatu formulir, prinsip-prinsip ini perlu diperhatikan :

a. Sedapat mungkin manfaatkan tembusan atau copy formulir.

b. Hindari duplikasi dalam pengumpulan data.

c. Buatlah rancangan formulir sesederhana dan seringkas mungkin.

d. Masukkanlah unsur internal check dalam merancang formulir. 
e. Cantumkan nama dan alamat perusahaan pada formulir yang akan digunakan untuk komunikasi dengan pihak luar.

f. Cantumkan nama formulir untuk memudahkan identifikasi.

g. Beri nomor untuk identifikasi formulir.

h. Cantumkan nomor pada sisi sebelah kiri formulir untuk memperkecil kemungkinan salah pengisian.

i. Cetaklah garis pada formulir, jika formulir tersebut akan diisi dengan tulisan tangan. Jika pengisian formulir akan dilakukan dengan mesin ketik, garis tidak perlu dicetak, karena mesin ketik akan dapat mengatur spasi sendiri, dan juga jika bergaris, pengisian formulir dengan mesin ketik akan memakan waktu yang lama.

j. Cantumkan nomor urut tercetak.

k. Rancanglah formulir tertentu sedemikian rupa sehingga pengisi hanya membubuhkan tanda $v$, atau $x$, dengan menjawab ya atau tidak, untuk menghemat waktu pengisiannya.

I. Susunlah formulir ganda dengan menyisipkan karbon sekali pakai, atau dengan menggunakan karbon beberapa kali pakai, atau cetaklah dengan kertas tanpa karbon (carbonless paper).

m. Pembagian zona sedemikian rupa sehingga formulir dibagi menurut blok-blok daerah yang logis yang berisi data yang saling terkait.

\section{Dokumen Sumber dan Dokumen Pendukung}


Ditinjau dari pengolahan data akuntansi, dokumen atau formulir digolongkan menjadi dua macam, yaitu

1. Dokumen sumber (source document)

Dokumen sumber adalah dokumen yang dipakai sebagai dasar pencatatan ke dalam jurnal atau buku pembantu, sedangkan dokumen pendukung adalah dokumen yang melampiri dokumen sumber sebagai bukti sahihnya transaksi yang direkam dalam dokumen sumber. Sebagai contoh dokumen yang digunakan untuk merekam transaksi penjualan terdiri dari faktur penjualan, yang merupakan dokumen sumber sebagai dasar pencatatan ke dalam jurnal

penjualan dan kartu piutang, yang dilampiri dengan surat jalan sebagai dokumen pendukung faktur penjualan tersebut.

6. Dokumen pendukung (supporting document)

Dokumen pendukung ini sebagai contoh berfungsi untuk membubuhkan sahihnya transaksi penjualan yang direkam dalam faktur penjualan. Surat order pengiriman membuktikan bahwa transaksi penjualan tersebut telah diotorisasi oleh bagian kredit. Dengan dilampirkannya berbagai dokumen pendukung tersebut, faktur penjualan sebagai dokumen yang dipakai sebagai sumber pencatatan ke dalam catatan akuntansi menjadi dapat diandalkan kesahihannya.

\subsection{Laporan Keuangan}

Tahap terakhir dari proses akuntansi adalah menyiapkan laporan keuangan. Laporan keuangan ada empat macam, yaitu : 
1. Lapora Laba Rugi (Income Statment)

Laporan ini menyajikan pendapatan dan biaya serta hasil bersih pemasukan atau kerugian bersih dari perusahaan untuk periode waktu tertentu.

2. Perubahan Modal (Capital Statment/Statment Of Equity)

Merangkum perubahan modal pemilik pada periode waktu tertentu.

3. Neraca (Balance Sheet)

Menyajikan kondisi aset, hutang, dan modal pemilik terhadap bisnisnya pada tanggal tertentu.

4. Arus Kas (Cash Flow)

Merangkum informasi tentang kas masuk (penerimaan kas), kas keluar (pembayaran) pada periode waktu tertentu.

\section{Prosedur}

Prosedur merupakan urutan atau langkah-langkah untuk menjalankan suatu pekerjaan, tugas atau kegiatan. Biasanya melibatkan beberapa orang dalam satu departemen atau lebih yang dibuat untuk menjamin penanganan secara seragam atas transaksi perusahaan yang terjadi berulang. Komponen-komponen tersebut memungkinkan SIA untuk memenuhi tiga fungsi penting dalam organisasi yaitu :

1. Mengumpulkan dan menyimpan data mengenai aktivitas yang dilakukan organisasi, resources yang dipengaruhi oleh events dan agents yang berpartisipasi dalam berbagai aktivitas sehingga manajemen, karyawan, dan pihak luar yang berkepentingan dapat melihat apa yang terjadi. 
2. Mengubah data ke dalam informasi yang berguna dalam pengambilan keputusan yang memungkinkan manajemen untuk merencanakan, melakukan, dan mengendalikan aktivitas.

3. Menyediakan pengendalian yang cukup untuk mengamankan aktiva organisasi, termasuk datanya, untuk memastikan bahwa data tersebut tersedia ketika dibutuhkan, dan akurat serta terpercaya. Jadi sistem informasi merupakan sebuah susunan dari orang, aktivitas, data, jaringan danteknologi yang terintegrasi yang berfungsi untuk mendukung dan meningkatkan operasi sehariharisebuah bisnis, juga menyediakan kebutuhan informasi untuk pemecahan masalah dan pengambilan keputusan oleh manajer. Untuk membangun sistem informasi, baikpersonal maupun multiuser, haruslah mengkombinasikan secara efektif komponenkomponensistem informasi, yaitu: prosedur kerja, informasi (data), orang dan teknologi informasi(hardware dan software).

4. Kegiatan klerikal (clerical operation) terdiri dari kegiatan berikut ini yang dilakukan untuk mencatat informasi dalam formulir, buku jurnal, dan buku besar :

1.Menulis

2.Menggandakan

3.Menghitung

4.Memberi kode

5.Mendaftar

6.Memilih (mensortasi)

7.Memindah 
8.Membandingkan.

Kegiatan-kegiatan di atas dapat dilakukan secara manual atau terkomputerisasi.

\subsection{Proses Dan Siklus Akuntansi}

Akuntansi merupakan proses dari 3 aktivitas yaitu mengidentifikasi, mencatat, dan mengkomunikasikan kejadian ekonomi dari sebuah organisasi. Proses yang pertama adalah identifikasi, yaitu memilih kegiatan yang termasuk kegiatan ekonomi. Proses kedua adalah mencatat, yaitu semua kejadian ekonomi tersebut dicatat untuk menyediakan sejarah dari kegiatan keuangan bagi organisasi tersebut. Proses ketiga adalah komunikasi, informasi yang telah didapat dari identifikasi dan pencatatan tidak akan berguna jika tidak dikomunikasikan.

Informasi ini dikomunikasikan melalui persiapan dan distribusi dari laporan akuntansi, yang paling umum disebut sebagai laporan keuangan. Menurut Mulyadi dalam bukunya yang berjudul Sistem Akuntansi dijelaskan bahwa sistem informasi akuntansi tidak lepas dari adanya siklus akuntansi yang meliputi urutan siklus sebagai berikut :

1. Analisis transaksi bisnis, seperti pengumpulan bukti-bukti transaksi yang terjadi.

2. Menjurnal transaksi-transaksi tersebut.

3. Mem-postingjurnal tersebut ke buku besar (Ledger).

4. Mempersiapkan neraca saldo.

5. Menjurnal dan mem-posting penyesuaian (jurnal penyesuaian).

6. Menyiapkan laporan keuangan, berupa laporan laba rugi (income statment), 
7. laporan perubahan equitas (capital statment),

8. neraca saldo (balance sheet).

9. Menjurnal dan mem-posting

10. penutup (jurnal penutup).

11. Menyiapkan neraca penutup.

\subsection{Karakteristik Sistem Informasi Akuntansi}

Menurut Cushing (1994 : 209) karakteristik SIA harus memiliki kriteria sebagai berikut:

1.Usefulness

sistem harus menghasilkan informasi yang berguna. Ini berarti informasi yang dihasilkan harus sesuai dengan kebutuhan (relevan) dan tepat waktu sehingga berguna bagi manajemen sebagai dasar pengambilan keputusan.

2.Economy,

seluruh komponen dari sistem harus dapat memberikan sumbangan yang lebih besar dan biaya yang dikeluarkan termasuk juga didalamnya semua laporan, pengendalian, mesin dan lain-lain yang tergolong dalam suatu sistem.

7. Reliability,

Produk dari suatu sistem harus dapat diandalkan. Informasi yang dihasilkan melalui suatu sistem harus dapat diandalkan dalam hal ketelitian yang tinggi dan sistem ini sendiri harus berperan secara efektif, bahkan saat alat-alat sudah tidak dapat dioperasikan.

8. Customer service 
Sistem harus berfungsi dalam memberikan pelayanan yang baik dan memuaskan bagi para pelanggannya sehingga sistem ini efisien dan efektif.

9. Capacity,

Suatu perusahaan harus memiliki kapasitas produksi yang memadai untuk menghadapi persaingan yang dihadapi perusahaan luar maupun dalam menghadapi kegitan operasi sehari-hari pada kapasitas yang penuh (full capacity).

10. Simplicity,

Sistem yang terlihat sederhana sehingga semua struktur operasinya dapat diikuti dengan mudah.

\section{Plexibility,}

Sistem ini harus berperan secara luwes dan menampung dan menerima semua perubahan yang bakal terjadi dalam perusahaan baik yang akan datang dari luar maupun dari dalam perusahaan itu sendiri.

\section{Metode Pengolahan Data Komputer}

Di dalam sistem informasi akuntansi berbasis komputer, transaksi yang terjadi diproses dengan menggunakan komputer. Pertama-tama, data transaksi harus diubah terlebih dahulu menjadi machine-readable form (dapat dibaca mesin) kemudian diolah dan disimpan. Data dalam machine-readale form akan diubah kembali menjadi human-readable form (dapat dibaca manusia) untuk digunakan oleh pengguna sistem. Komputer pada dasarnya hanya merupakan alat bantu yang digunakan dalam 
pengolahan data. Proses pengolahan data terbagi atas empat tahap utama yang terdapat pada sistem manual maupun sistem berbasis komputer, yaitu :

1. Data input, pada tahap data input, data transaksi dikumpulkan dan dikonversikan ke dalam machinereadable form.

2. Data transaksi, dikelompokkan dan diperiksa terlebih dahulu agar pengolahan data berlangsung lebih efisien dan efektif. Pada sistem yang berbasis komputer, data transaksi dimasukkan kedalam online terminal atau microcomputer.

3. Operator memasukkan data dengan mengetik data transaksi pada terminal yang ada, selain itu dapat juga menggunakan alat yang dikenal sebagai source data automation.

4. Alat ini merekam data transaksi dalam machine-readable form pada tempat dan waktu yang sama dengan sumbernya.

5. Data storage

Data bagi perusahaan merupakan salah satu sumber yang penting yang harus dijaga, tetapi tidak semua data yang relevan dapat dipergunakan. Sebuah perusahaan harus mempunyai akses yang cepat dan mudah atas datanya untuk dapat berfungsi dengan baik. Oleh karena itu, para akuntan harus memahami pengelolaan dan penyimpanan data dalam sebuah sistem informasi akuntansi dan bagian data dapat diakses.Dalam 
suatu perusahaan, data disimpan dalam bentuk files. Tiap jenis data dan tujuan penyimpanan memerlukan jenis file yang berbeda.Ada beberapa jenis file yaitu : master file, transaction file, table file, backup file, suspense file, report file.

6. Data processing, pada tahap data processing, data transaksi dimanipulasi untuk menghasilkan informasi yang berguna. Dalam tahap ini dilakukan beberapa aktivitas pengolahan data seperti calculating, comparing, summarizing, filtration, dan retrieval.

Selain aktivitas ini terdapat aktivitas lainnya yaitu data maintenance. Aktivitas ini berfungsi untuk menjaga data tetap up to date.

7. Data maintenance, dibagi dalam empat aktivitas, yaitu additions, deletions, updates dan changes. Data dalam suatu sistem informasi akuntansi dapat diproses dalam sequential file processing atau random access file processing. Pada sequential file processing data diolah secara berurutan. Proses ini berfungsi secara cepat dan efisien jika data yang diolah berjumlah besar dan sebagian besar data diolah secara periodik untuk data yang jarang di-update. Pengolahan data secara direct access lebih baik digunakan untuk data yang diolah secara konstan dan sering di-update. Transaksi yang terjadi dapat diproses secara on-line processing atau batch processing. Dalam batch processing, transaksi-transaksi yang serupa dikumpulkan dalam suatu kelompok secara periodik 
sebelum diolah. Pada online processing transaksidicatat melalui suatu alat atau terminal yang dihubungkan pada komputer. Pada on-line processing terdapat dua bentuk pengolahan data:

a. On-line batch, yaitu data dimasukkan langsung kedalam suatu sistem komputer, disimpan secara elektronis dan diproses belakangan.

b. On-line real-time, yaitu data dimasukkan kedalam sistem langsung diproses seketika dan menghasilkan informasi up to date.

c. Information output, tahap terakhir dari proses pengolahan data adalah menghasilkan informasi. Informasi yang dihasilkan biasanya disajikan dalam bentuk documents, reports, response to query.

\section{Sub-Sistem Sistem Informasi Akuntasi}

Dalam hal perancangan sistem informas akuntansi dengan mengacu pada buku yang berjudul Sistem Informasi Akuntansi Buku 2, karya James A. Hall yang menerangkan salah satu sub sistem dari sistem informasi akuntansi yaitu Sistem Pemrosesan Transaksi (SPT). Sistem pemrosesan transaksi (transaction processing system) merupakan pusat dari seluruh fungsi sistem informasi dengan :

- Mengkonversikan peristiwa ekonomi ke transaksi keuangan.

- Mencatat transaksi informasi keuangan dalam record akuntansi (jurnal dan buku besar). 
- Mendistribusikan informasi keuangan yang utama ke personel operasi untuk mendukung kegiatan operasi harian mereka.

- Sistem pemrosesan transaksi dengan volume transaksi tinggi, jenis transaksi dikelompokkan dalam siklus transaksi, yang terdiri dari tiga siklus yaitu siklus pendapatan, siklus pengeluaran, dan siklus konversi. 


\section{BAGIAN 4}

SISTEM PENJUALAN KREDIT DAN SISTEM AKUNTANSI PIUTANG

\section{TUJUAN INSTRUKSIONAL UMUM :}

Mampu menjelaskan dan Mengaplikasikan (membuat) Siklus Pendapatan : Penjualan dan Penerimaan Kas

\section{SUB BAGIAN :}

4.1. Sistem informasi siklus pendapatan/Penerimaan Kas

\section{Sitem Akuntansi Penerimaan Kas}

Penerimaan kas perusahaan berasal dari dua sumber utama : penerimaan kas dari penjualan tunai dan penerimaan kas dari piutang. Dalam bab ini diuraikan penerimaan kas dari penjualan Over-the Counter Sale, dari Cash-on-Deliverry Sale, dan dari Credit Card Sale. Di samping itu, diuraikan pula penerimaan kas dari piutang melalui penagihan perusahaan, kantor pos dan lock-boxcollection plan.( Mulyadi , $2001: 455$ )

\section{Pengertian Penjualan}

Dalam arti luas penjualan dapat diartikan sebagai penyerahan hak milik atas barang atau jasa dari pihak 
penjual kepada pihak pembeli baik secara kredit maupun tunai. Menurut Ikatan Akuntan Indonesia (IAI) dalam Standar Akuntansi Keuangan :

"Penjualan dapat diartikan sebagai kenaikan manfaat ekonomi selama satu periode akuntansi dalam bentuk pemasukan atau penambahan aktiva atau penurunan kewajiban yang mengakibatkan kenaikan ekuitas yang tidak berasal dari kontribusi penanaman modal".

Penjualan dikelompokkan menjadi dua, yaitu :

1. Penjualan tunai

Penjualan dimana pembeli diharuskan membayar ke bagian kasir apabila barang sudah diserahkan oleh penjual.

2. Penjualan kredit

Dalam penjualan kredit ini, pembeli diberikan jangka waktu untuk pembayarannya, biasanya pembayaran dilakukan 30 hari setelah barang diserahkan kepada pembeli.

Penjualan tunai dilaksanakan oleh perusahaan dengan cara mewajibkan pembeli melakukan pembayaran harga barang lebih dahulu sebelum barang diserahkan oleh perusahaan kepada pembeli. Setelah uang diterima oleh perusahaan, barang kemudian diserahkan kepada pembeli dan transaksi penjualan tunai kemudian dicatat oleh perusahan.

Sumber penerimaan kas terbesar suatu perusahaan dagang, seperti toko buku, berasal dari transaksi penjualan tunai. 
Berdasarkan sistem pengendalian internal yang baik, sistem penerimaan kas dari penjualan tunai mengharuskan :( Mulyadi , $2001: 455$ ).

a. Penerimaan kas dalam bentuk harus segera disetor ke Bank dalam jumlah penuh dengan melibatkan pihak lain selain kasir untuk melakukan internal check.

b. Penerimaan kas dari penjualan tunai dilakukan melalui transaksi kartu kredit, yang melibatkan bank penerbit kartu kredit dalam pencatatan transaksi penerimaan kas.

Sistem penerimaan kas dari penjualan tunai dibagi menjadi tiga (3) prosedur antara lain:( Mulyadi , 2001 : 456)

1. Penerimaan Kas dari Over-the Counter Sale

Dalam penjualan tunai ini, pembeli datang keperusahaan, melakukan pemilihan barang atau produk yang akan dibeli, melakukan pembayaran ke kasir, dan kemudian menerima barang yang dibeli. dalam Over-the Counter Sale ini, perusahaan menerima uang tunai, cek pribadi (Personal Check), atau pembayaran langsung dari pembeli dengan credit card, sebelum barang diserahkan kepada pembeli. Penerimaan kas dari Over-the Counter Sales dilaksanakan melalui prosedur berikut ini : (Mulyadi , 2001 : 456)

a. Pembelian memesan barang langsung kepada wiraniaga ( Sales Person) di Bagian Penjualan. 
b. Bagian kasa menerima pembayaran dari pembeli, yang dapat berupa uang tunai, cek pribadi ( personal check) atau kartu kredit.

c. Bagian pengiriman menyerahkan barang keoada pembeli.

d. Bagian kasa menyetorkan kas yang diterima ke bank.

e. Bagian Akuntansi mencatat pendapatan penjualan dalam jurnal penjualan.

f. Bagian Akuntansi mencatat penerimaan kas dari penjualan tunai dalam jurnal penerimaan kas.

Jika kas yang diterima cek pribadi, bank penjual ( bank yang penjual miliki rekening giro didalamnya) kemudian akn mengurus check clearing tersebut ke bank pembeli ( bank yang pembeli memiliki rekening giro didalamnya). Jika kas yang diterima berupa kartu kredit, bank penjual merupakan bank penerbit kartu kredit langsung menambah saldo rekening giro penjual setelah dikurangi dengan credit card fee ( yang berkisar 2,5\% sampai dengan 4\% ). Bank penerbit kartu kredit inilah yang secara periodik melakukan penagihan kepada pemegang kartu kredit.

\section{Penerimaan Kas dari COD Sale}

Cash on delivery sales (COD sales) adalah transaksi penjualan tunai yang melibatkan kantor pos, perusahaan angkutan umum, atau angkutan sendiri dalam penyerahan dan penerimaan kas dari hasil penjualan. COD Sales merupakan sarana untuk barang bagi pembeli dan Jaminan penerimaan kas bagi 
perusahaan penjual. COD sales melalui pos belum merupakan sistem penjualan yang umum berlaku di Indonesia. COD sales melalui pos dilaksanakan dengan prosedur sebagai berikut :( Mulyadi , $2001: 457$ ).

1. Pembeli memesan barang lewat surat yang dikirim melalui pos.

2. Penjual mengirimkan barang melalui kantor pos pengirim dengan cara mengisi formulir COD sales di Kantor pos.

3. Kantor pos pengirim mengirim barang dan formulir COD sales sesuai dengan instruksi penjual kepada kantor pos penerima.

4. Kantor pos penerima, pada saat diterimanya barang dan formulir COD sales, memberitahukan kepada pembeli tentang diterimannya kiriman barang COD Sales.

5. Pembeli membawa surat panggilan ke kantor pos penerima dan melakukan pembayaran sejumlah yang tercantum dalam formulir COD Sale. Kantor pos penerima menyerahkan barang kepada pembeli, dengan diterimannya kas dari pembeli.

6. Kantor pos penerima memberitahu kantor pos pengirim bahwa COS Sale telah dilaksanakan.

7. Kantor pos penerima memberitahu kantor pos pengirim bahwa COD sale telah dilaksanakan, sehingga penjual dapat mengambil kas yang diterima dari pembeli.

Jika lokasi pembeli berada di kota yang sama dengan lokasi perusahaan, penyerahan barang baiasanya dilaksanakan sendiri oleh fungsi pengiriman perusahaan. Pencatatatan COD Sale dilakukan dua jurnal sebagai berikut : 
Jurnal penjualan. Pasa saat barang dikirim. Bagian jurnal membuat jurnal sebagai berikut :

$\begin{array}{ll}\text { Pendapatan tunai } & x x x \\ \text { Pendapatan Penjualan COD } & x x x \\ \text { PPN Keluaran } & \end{array}$

Jurnal penerimaan kas. Pada saat kas diterima oleh Bagian Kasa, Bagian Jurnal membuat jurnal membuat jurnal dalam jurnal peneimaan kas sebagai berikut :

Kas

$\mathrm{XXX}$

Penjualan Tunai

$x x x$

Jika COD sale dilakukan oleh perusahaan kepada pembeli luar kota atau luar pulau, pengiriman dan penagihan harga barang dapat dilakukan lewat kantor pos atau perusahaan angkutan umum. Pencatatan COS sale dilakukan pada saat barang diserahkan kepada kantor pos atau perusahaan angutan umum, dengan jurnal sebagi berikut :

\begin{tabular}{|c|c|}
\hline Piutang COD & $x x x$ \\
\hline PPN Keluaran & $x x x$ \\
\hline Penjualan COD & \\
\hline Biaya Angkutan & $x x x$ \\
\hline
\end{tabular}

Pada saat kas diterima dari pembeli melalui kantor pos atau perusahaan angkutan umum, jurnal untuk mencatat transaksi tersebut adalah :

Kas XXX

Piutang COD

Xxx 
3). Penerimaan Kas dari Credit Card Sale

Sebenarnya credit card bukan merupakan suatu tipe penjualan namun merupakan salah satu cara pembayaran bagi pembeli dan sarana penagihan bagi penjual, yang memberikan kemudahan baik bagi pembeli maupun bagi penjual. Credit card merupakan sarana pembayaran bagi pembeli, baik dalam over the counter sale maupun dalam penjualan yang pengiriman barangnya dilaksanakan melalui jasa kantor pos atau angkutan umum. Dalam Over the Countre sale, pembeli datang ke perusahaan, melakukan pemilihan barang atau produk yang akan dibeli, melakukan pembayaran ke kasir dengan menggunakan kartu kredit. Dalam penjualan tunai yang melibatkan pos atau perusahaan angkutan umum, pembeli tidak perlu datang ke perusahaan ke perusahaan penjual. Pembeli memberi persetujuan tertulis penggunaan kartu kredit dalam pembayaran harga barang, sehingga memungkinkan perusahaan penjual melakukan penagihan kepada bank atau perusahaan penerbit kartu kredit.

Kartu kredit digolongkan dalam tiga ( 3 ) kelompok :( Mulyadi, $2001: 459$ )

a.Kartu Kredit Bank ( Bank Cards )

Kartu Kredit Bank ( Bank Card) diterbitkan oleh Bank atau lembaga keuangan yang lain. Kartu Kredit yang beredar adalah Visa dan Master Card. Dengan menggunakan kartu kredit ini, pembeli sebenarnya memperoleh kredit dari Bank. Perusahaan 
yang menerima pembayaran melalui kartu kredit dapat memperoleh uang tunai segera dari bank dengan menukarkan Copy Credit Card Sales Slip ke Bank yang menerbitkan kartu kredit biasanya menagih pemegang kartu kredit sebulan sekali, untuk transaksi pembelian dengan menggunakan kartu kredit yang dilakukan oleh pemegang kartu kredit dalam jangka waktu sebulan sebelumnya. Rerangka hubungan antara Bank penerbit kartu kredit, penerbit kartu kredit, dan penjual barang ( disebut dengan istilah Merchant ), memberikan manfaat kepada semua pihak yang berkaitan tersebut. Penjual barang dijamin dapat menerima uang tunai dengan segera dari bank penerbit kartu kredit, satu bulan, dan bank penerbit kartu kredit menerima credit card fee dari penjual.

b.Kartu Kredit Perusahaan ( Company Cards )

Kartu kredit ini diterbitkan oleh perusahaan tertentu untuk para pelanggannnya. Pelanggan dapat menggunakan kartu kredit ini untuk membeli barang hanya ke perusahaan yang menerbitkan kartu kredit tersebut. Pada akhir bulan atau pada tanggal tertentu, perusahaan menagih jumlah harga barang yang dibeli oleh pemegang kartu kredit selama jangka waktu tertentu yang telah lewat.

c. Kartu Kredit berpergian dan Hiburan ( Travel and Entertaiment Cards).

Diner's Club dan Carte Blance biasanya digolongkan ke dalam travel and entertaiment cards karena pada umumnya kartu - kartu kredit tersebut digunakan dalam bisnis Restaurant, Hotel, dan Motel. Namun, banyak pula toko yang menerima kartu kartu kredit tersebut sebagai alat pembayaran. Perusahaan penjual barang menguangkan credit card sales slip dari transaksi 
penjualannya ke perusahaan yang menerbitkan kartu kredit tersebut. Jurnal untuk mencatat transaksi penjualan dengan menerima kartu kredit jenis ini tida berbeda dengan jurnal penjualan dengan menerima kartu kredit bank.

Credit card sale adalah transaksi penjualan tunai ( yang merupakan bentuk lain Over the Counter sale) yang pembeli melakukan pembayaran dengan menggunakan kartu kredit.

\section{Fungsi yang Terkait}

Fungsi yang terkait dalam sistem penerimaan kas dari penjualan tunai adalah :( Mulyadi , $2001: 462$ )

a. Fungsi Penjualan

Dalam transaksi penerimaan kas dari penjualan tunai, fungsi ini bertanggung jawab untuk menerima order dari pembeli, mengisi faktur penjualan tunai, dan menyerahkan faktur tersebut kepada pembeli untuk kepentingan pembayaran harga barang ke fungsi kas.

c. Fungsi Kas

Dalam transaksi penerimaan kas daripenjualan tunai, fungsi ini bertanggung jawab sebagai penerima kas dari pembeli.

d. Fungsi Gudang

Dalam transaksi penerimaan kas dari penjualan tunai, fungsi ini bertanggung jawab untuk menyiapkan barang yang dipesan oleh pembeli, serta menyerahkan barang tersebut ke fungsi pengiriman.

e. Fungsi Pengiriman 
Dalam transaksi penerimaan kas adari penerimaan kas dari penjuakan tunai, fungsi ini bertanggung jawab untuk membungkus barang dan menyerahkan barang yang telah dibayar hargannya kepada pembeli.

f. Fungsi Akuntansi

Dalam transaksi penerimaan kas dari penjualan tunai, fungsi ini bertanggung jawab sebagai pencatat transaksi penjualan, penerimaan kas dan pembuat laporan penjualan.

\subsection{Informasi yang Diperlukan oleh Manajemen}

Informasi yang umumnya diperlukan oleh manajemen dari penerimaan kas dari penjualan tunai adalah (Mulyadi , 2001 : 462):

a. Jumlah pendapatan penjualan menurut jenis produk atay kelompok produk selama jangka waktu tertentu.

b. Jumlah kas yang diterima dari penjualan tunai.

c. Jumlah harga pokok produksi yang dijual selama jangka waktu tertentu.

d. Nama dan alamat pembeli. Informasi ini diperlukan dalam penjualan produk tertentu, namun pada umumnya informasi nama dan alamat pembeli ini tidak diperlukan oleh manajemen dari kegiatan penjualan tunai.

e. Kuantitas produk yang dijual.

f. Otorisasi pejabat yang berwenang.

\section{Dokumen yang digunakan}

Dokumen yang digunakan dalam sistem penerimaan kas dari penjualan tunai adalah :( Mulyadi , $2001: 463$ ) 
a. Faktur Penjualan Tunai

Dokumen ini digunakan untuk merekam berbagai informasi yang diperlukan oleh manajemen mengenai transaksi penjualan tunai. Jika diliat kembali daftar informasi yang diperlukan oleh manajemen mengenai transaksi penjualan tunai tersebut, maka formulir faktur penjualan tunai dapat digunakan untuk merekam data mengenai nama pembeli dan alamat pembeli, tanggal transaksi, kode dan nama barang, kuantitas, harga satuan, jumlah harga, nama da kode wiraniaga, otorisasi terjadinya berbagai tahap transaksi. Faktur penjualan tunai diisi oleh fungsi penjualan yang bersifat sebagai pengantar pembayaran oleh pembeli kepada fungsi kas dan sebagai dokumen sumber untuk pencatatan transaksi penjualan ke dalam jurnal penjualan. Tembusan faktur ini dikirimkan oleh faktur penjualan ke fungsi pengiriman sebagai perintah penyerahan barang kepada pembeli yang telah melaksanakan pembayaran harga barang ke fungsi kas. Tembusan faktur ini juga berfungsi sebagai slip pembungkus ( packing slip ) yang telah ditempelkan oleh fungsi pengiriman di atas pembungkus, sebagai alat identifikasi bungkusan barang.

b. Pita Register Kas

Dokumen ini dihasilkan oleh fungsi kas dengan cara mengoperasikan mesin register kas ( cash register ). Pita register kas ini merupakan bukti peberimaan kas yang dikeluarkan oleh fungsi kas dan merupakan dokumen pendukung faktur penjualan tunai yang dicatat dalam jurnal penjualan.

c. Credit Card Sales Slip 
Dokumen ini dicetak oleh credit card center bank yang menerbitkan kartu kredit dan diserahkan kepada perusahaan ( disebut merchant ) yang menjadi anggota kartu kredit. Bagi perusahaan yang menjual barang atau jasa. Dokumen ini diisi oleh fungsi kas dan berfungsi sebagai laat untuk menagih uang tunai dari bank yang mengeluarkan kartu kredit, untuk transaksi penjualan yang telah dilakukan kepada pemegang kartu kredit.

d. Bill of lading

Dokumen ini merupakan bukti penyerahan barang bagi perusahaan penjualan barang kepada perusahaan angkutan umum. Dokumen ini digunakan oleh fungsi pengiriman dalam penjualan COD yang menyerahkan barangnya dilakukan oleh perusahaan angkutan umum.

e. Faktur Penjualan COD

Dokumen ini digunakan untuk merekam penjualan COD. Tembusan faktur penjualan COD diserahkan kepada pelanggan melalui bagian angkutan perusahaan, kantor pos, atau perusahaan angkutan umum dan dimintakan tanda tangan penerima barang dari pelanggan sebagai bukti telah diterimannya barang oleh pelanggan. Tembusan faktur penjualan COD digunakan oleh perusahaan untuk menagih kas yang harus dibayar oleh pelanggan pada saat penyerahan barang yang dipesan oleh pelanggan.

f. Bukti setor Bank

Dokumen ini dibuat oleh fungsi kas sebagai bukti penyetoran kas ke bank. Bukti setoran dibuat 3 lembar dan diserahkan oleh fungsi kas ke Bank, bersamaan dengan penyetoran kas dari hasil penjualan tunai ke Bank. Dua lembar tembusannya diminta kembali dari bank setelah ditandatangani 
dan dicap oleh bank sebagai bukti penyetoran kas ke bank. Bukti setor bank diserahkan oleh fungsi kas kepada fungsi akuntansi, dan dipakai oleh fungsi akuntansi sebagai dokumen sumber untuk pencatatan transaksi penerimaan kas dari penjulan tunai ke dalam jurnal penerimaan kas.

g. Rekapitulasi harga pokok penjualan

Dokumen ini digunakan oleh fungsi akuntansi untuk meringkas harga pokok produk yang dijual selama satu periode. Dokumen ini digunakan oleh fungsi akuntansi sebagai dokumen pendukung bagi pembuatan bukti memorial untuk mencatat harga pokok produk yang dijual.

\subsection{Catatan Akuntansi yang digunakan}

Catatan akuntansi yang digunakan dalam sistem penerimaan kas dari penjualan tunai adalah :( Mulyadi , 2001 : 468)

a. Jurnal Penjualan

Jurnal penjualan digunakan oleh fungsi akuntansi untuk mencatat dan meringkas data penjualan. Jika perusahaan menjual berbagai macam produk dan manajemen memerlukan informasi pejualan setiap jenis produk yang dijualnya selama jangka waktu tertentu

b. Jurnal Penerimaan Kas

Jurnal penerimaan kas digunakan oleh fungsi akuntansi untuk mencatat penerimaan kas dari berbagai sumber, di antaranya dari penjualan tunai.

c. Jurnal Umum

Dalam transaksi penerimaan kas dari penjualan tunai, jurnal digunakan oleh fungsi akuntansi untuk mencatat harga pokok produk yang dijual.

d. Kartu Persediaan 
Dalam transaksi penerimaan kas dari penjualan tunai, kartu persediaan digunakan oleh fungsi akuntansi untuk mencatat berkurangnya harga pokok produk yang dijual. Kartu persediaan ini diselenggarakan di fungsi akuntansi untuk mengawasi mutasi dan persediaan barang yang disimpan di gudang.

e. Kartu Gudang

Catatan ini tidak termasuk sebagai catatan akuntansi karena hanya berisi data kuantitas yang disimpan di gudang. Catatan ini diselenggarakan oleh fungsi gudang untuk mutasi dan persediaan barang yang disimpan dalam gudang. Dalam transaksi penjualan tunai, kartu gudang digunakan untuk mencatat berkurangnya kuantitas produk yang dijual.

\section{Jaringan Informasi yang Membentuk Sistem}

Jaringan prosedur yang membentuk sistem penerimaan kas dari penjualan tunai adalah sebagai berikut :( Mulyadi , 2001 : 469)

a. Prosedur order penjualan

Dalam prosedur ini fungsi penjualan menerima order dari pembeli dan membuat faktur penjualan tunai untuk memungkinkan pembeli melakukan pembayaran harga barang ke fungsi kas dan untuk memungkinkan fungsi gudang dan fungsi pengiriman menyiapkan barang yang akan diserahkan kepada pembeli.

b. Prosedur penerimaan kas

Dalam prosedur ini fungsi kas menerima pembayaran harga barang dari pembeli dan memberikan tanda pembayaran ( berupa pita register kas dan cap "lunas" pada faktur penjualan tunai ) kepada pembeli untuk memungkinkan pembeli tersebut 
melakukan pengambilan barang yang dibelinnya dari fungsi pengiriman.

c. Prosedur penyerahan barang

Dalam prosedur ini fungsi pengiriman menyerahkan barang kepada pembeli.

d. Prosedur pencatatan penjualan tunai

Dalam prosedur ini fungsi akuntansi melakukan pencatatan transaksi penjualan tunai dalam jurnal penjualan dan jurnal penerimaan kas. Disamping itu, fungsi akuntansi juga mencatat berkurangnya persediaan barang yang dijual dalam kartu persediaan.

e. Prosedur penyetoran kas ke bank

Sistem pengendalian intern terhadap kas mengharuskan penyetoran dengan segera ke bank semua kas yang diterima pada suatu hari. Dalam prosedur ini fungsi kas menyetorkan ke Bank dalam jumlah penuh.

f. Prosedur pencacatan penerimaan kas

Dalam prosedur ini fungsi akutansi mencatat penerimaan kas ke dalam jurnal penerimaan kas berdasarkan bukti setor bank yang diterima dari bank melalui fungsi kas.

g. Prosedur pencatatan harga pokok penjualan

Dalam prosedur ini, fungsi akuntansi membuat rekapitulasi harga pokok penjualan berdasarkan data yang dicatat dalam kartu persediaan. Berdasarkan rekapitulasi harga pokok penjualan, fungsi akuntansi membuat bukti memorial sebagai dokumen sumber untuk pencatatan harga pokok penjualan ke dalam jural umum. 


\subsection{Unsur Pengendalian Intelrn}

Unsur pengendalian intern yang seharusnya ada dalam system penerimaan kas dari penjualan tunai antara lain :( Mulyadi , 2001 : 470 )

a. Organisasi

Dalam merancang organisasi yang berkaitan dengan sistem penerimaan kas dari penjualan tunai, unsur pokok pengendalian intern dijabarkan sebagai berikut :

- Fungsi Penjualan Harus Terpisah dengan Fungi Kas.

Fungsi penjualan yang merupakan fungsi operasi harus dipisahkan dari fungsi kas yang merupakan fungsi penyimapanan. Pemisahan ini mengakibatkan setiap penerimaan kas dari penjualan tunai dilaksanakan oleh dua fungsi yang saling mengecek. Penerimaan kas dilakukan oleh bagian kasa akan dicek kebenarannya oleh Bagian Order Penjualan, karena dalam sistem inpenjualan tunai transaksi penerimaan kas dari penjualan tunai tidak akan terjadi tanpa diterbitkannya faktur penjualan tunai oleh Bagan Order Penjualan.

- Fungsi Kas Harus Terpisah dengan Fungsi Akuntansi.

Berdasarkan unsur sistem pengendalian intern yang baik, fungsi akuntansi harus dipisahkan dari kedua fungsi pokok yang lain : fungsi operasi dan fungsi penyimpanan. Hal ini dimaksudkan untuk menjaga kekayaan perusahaan dan menjamin ketelitian dan keandalan data akuntansi. Dengan kata lain, suatu sistem yang menggabungkan fungsi akuntansi dengan kedua fungsi pokok yang lain : fungsi operasi dan fungsi penyimapanan akan membuka kesempatan bagi karyawan perusahaan untuk melakukan kecurangan dengan mengubah catatan akuntansi untuk menutupi 
kecurangan yang dilakukannya. Fungsi kas berada di tangan Bagian Kasa dan fungsi akuntansi berada di tangan Bagian Jurnal. Pemisahan kedua fungsi pokok ini akan mencegah terjadinya penggunaan kas dari penjualan tunai oleh Bagian Kasa untuk kepentingan pribadi.

- Transaksi Penjualan Tunai Dilakasanakan oleh Fungsi Penjualan, Fungsi Kas, Fungsi Pengiriman dan Fungsi Akuntansi. Tidak ada transaksi penjualan tunai yang dilaksanakan secara lengkap hanya oleh satu fungsi tersebut. Dengan dilaksanakannya pengecekan intern pekerjaan setiap fungsi tersebut oleh fungsi yang lain.

\section{Sistem Otorisasi dan Prosedur Pencatatan}

- Menerima Order dari Pembeli Diotorisasi oleh Fungsi Penjualan Dengan Menggunakan Formulir Faktur Penjualan Tunai. Transaksi penjualan tunai dimulai dengan diterbitkannya faktur penjualan tunai oleh fungsi penjualan. Dengan formulir ini fungsi penerimaan kas akan menerima kas dan fungsi pengiriman akan menyerahkan barang kepada pembeli. Faktur penjualan tunai harus diotorisasi oleh fungsi penjualan agar menjadi dokumen yang sahih, yang dapat digunakan sebagai dasar bagi fungsi pengiriman untuk menyerahkan barang kepada pembeli setelah harga barang dibayar oleh pembeli tersebut, serta sebagai dokumen sumber untuk pencatatan dalam catatan akuntansi.

- Penerimaan Kas Diotorisasi oleh Fungsi Penerimaan Kas dengan Cara Membubuhakan Cap " Lunas" Pada Faktur Penjualan Tunai dan Penempelan Pita Register Kas pada Faktur Tersebut. Sebagai bukti bahwa fungsi penerimaan kas telah menerima kas dari pemebli, fungsi tersebut harus membubuhkan cap " lunas" dan 
menempelkan pita registerkas tersebut dokumen faktur penjualan tunai dapat memberikan otorisasi bagi fungsi pengiriman untuk menyerahkan barang kepada pembeli.

- Penjualan dengan Kartu Kredit Bank didahului dengan Otorisasi dari Bank Penerbit Kartu Kredit. Masalah yang dihadapi oleh merchant dalam penjualan dengan kartu kredit dari Bank adalah penrntuan bonafiditas pemegang kartu kredit dalam sistem yang Online, mercahnt dilengkapi dengan suatu akat yang dihubungkan dengan cara memasukkan kartu kredit pelanggan kedalam alat tersebut. Dengan alat ini merchant terhindar dari kemungkinan ketidakbonafitan pemegang kartu kredit.

- Penyerahana Barang Diotorisasi oleh Fungsi Pengiriman Dengan Cara Membubuhkan Cap " sudah diserahkan pada Faktur Penjualan Tunai. Cap yang sudah diserahkan yang dibubuhkan oleh fungsi pengiriman pada faktur penjualan tunai membuktikan telah diserahkannya barang kepada pembeli yang berhak.

- Pencatatan ke dalam Catatan Akuntansi Harus Didasarkan atas Dokumen Sumber yang Dilampiridengan Dokumen Pendukung yang Lengkap.Catatan informasi yang berasal dari dokumen sumber yang sahih. Kesahihan dokumen sumber dibuktikan dengan dilampirkannya dokumen pendukung yang lengkap, yang telah diotorisasi oleh pejabat yang berwenang.

- Pencatatan ke dalam Catatan Akuntansi Harus dilakukan oleh Karyawan yang Diberi Wewenang untuk Itu. Setiap pencatatan kedalam akuntansni harus dilakukan oleh karyawan yang diberikan wewenang untuk mengubah catatan akuntansi tersebut. Sehabis karyawan tersebut memmutakhirkan catatan akuntansi berdasarkan sember, ia harus membubuhka tanda 
tangan dan tanggal pada dokumen sumber sebagai bukti telah dilakukannya pengubahan data yang dicatat dalam catatan akuntansi pada tanggal tersebut.

\section{Praktik yang Sehat}

- Faktur penjualan Tunai Bernomor Urut Cetak dan Pemakaiannya Dipertaggungjawabkan oleh Fungsi Penjualan. Dalam organisasi ini, setiap transaksi keuangan hanya akan terjadi jika medapat otorisasi dari yang berwenang. Otorisasi dari yang berwenang tersebut diwujudkan dalam bentuk tanda tangan pada formulir.

- Jumlah Kas yng Diterima dari Penjualan Tunai Disetorkan Seluruhnya ke Bank pada Hari yang Sama dengan Trnasaksi Penjualan Tunai atau Hari Kerja Berikutnya. Penyetoran segera seluruh jumlah kas yang diterima dari penjualan tunai ke Bank akan menjadikan jurnal kas perusahaan dapat diuji ketelitian dan keandalannya dengan menggunakan informasi dari bank yang tercantum dalam rekening koran bank.

- Perhitungan Saldo Kas yang Ada di Tangan Fungsi Kas Secara Periodik dan Secara Mendadak oleh Fungsi Pemeriksaan Intern. Perhitungan secara periodik dan secara mendadak akan mengurangi resiko penggelapan kas yang diterima oleh kasir. Dalam perhitungan fisik ini dilakukan pencocokan anatara jumlah kas hasil hitungan dengan jumlah kas yang seharusnya ada menurut faktur penjualan tunai dan bukti penerimaan kas yang lain. 


\section{Bagan Alir Dokumen}

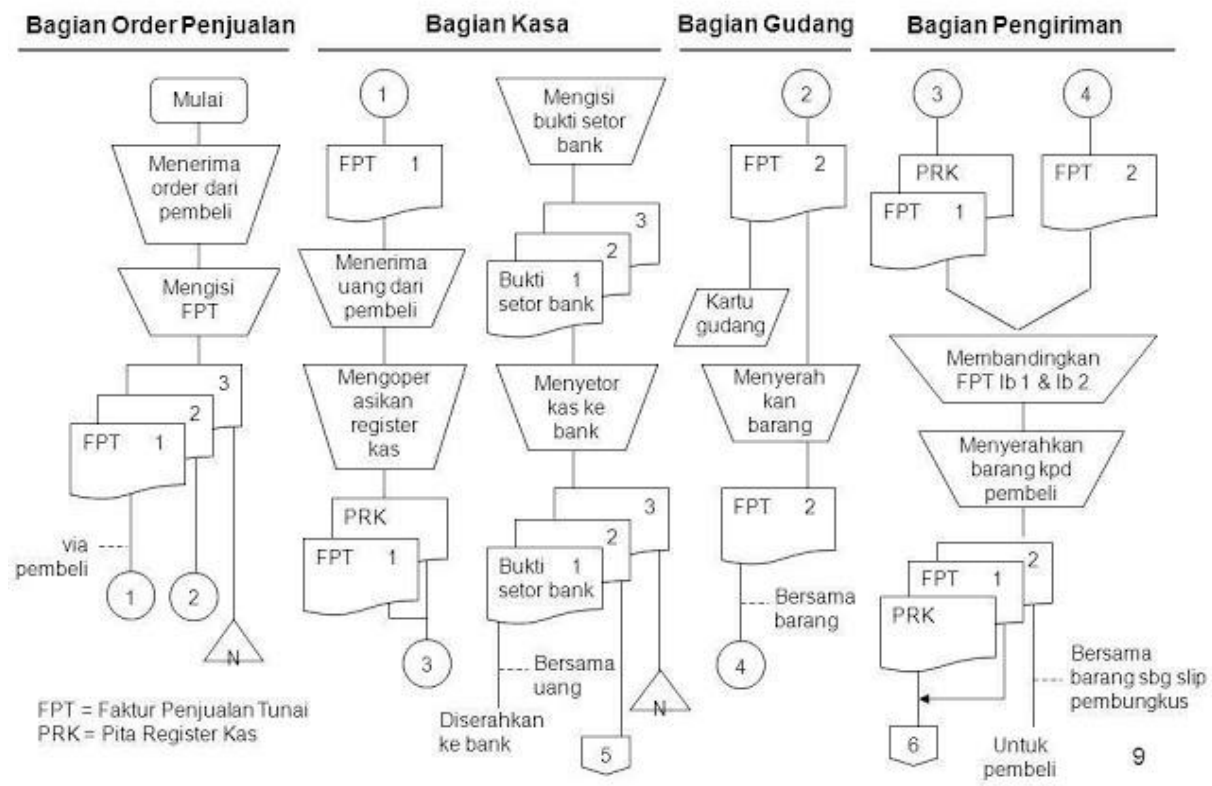

Gambar . Siste Sistem Penerimaan Kas dari Over-the-counter Sale (Mulyadi , $2001: 476$ )

\section{Sistem Akuntansi Penerimaan Kas dari Piutang}

Sumber penerimaan kas suatu perusahaan manufaktur biasannya berasal dari pelunasan piutang dari debitur, karena sebagian besar produk perusahaan tersebut berasal dari penjualan kredit. Dalam perusahaan tersebut penerimaan kas dari penjualan tunai biasanya merupakan sumber penerimaan kas relatif kecil. Dalam perusahaan dagang, seperti toko pengecer, sumber penerimaan 
kas terbesar berasal dari transaksi penjualan tunai. Berdasarkan sistemn pengendalian intern yang baik, sistem penerimaan kas dari piutang harus menjamin diterimannya kas dari debitur oleh perusahaan, bukan kas oleh karyawan yang berhak menerimanya. Untuk menjamin diterimannya kas oleh perusahaan, sistem penerimaan kas dari piutang mengharuskan :( Mulyadi , 2001 : 482)

1. Debitur melakukan pembayaran dengan cek atau dengan cara pemindahbukuan melalui rekening Bank. Jika perusahaan hanya menerima kas dalam bentuk cek debitur, yang ceknya atas nama perusahaan akan menjamin kas yang diterima oleh perusahaan masuk ke rekening giro bank perusahaan. Pemindahbukuan juga akan memberikan jaminan penerimaan kas masuk rekening giro bank perusahaan.

2. Kas yang diterima dalam bentuk cek dari debitur harus segera disetor ke bank dalam jumlah penuh.

3. Penerimaan kas dari piutang yang dilakukan melalui penagiahan perusahaan , melalui pos dan melalui lock-box collection plan. Diantara berbagai cara penagihan piutang tersebut, penerimaan kas dari piutang seharusnya mewajibkan debitur melakukan pembayaran dengan meggunakan cek atas nama, yang secara 
jelas mencantumkan nama perusahaan yang berhak menerima kas dari debitur, sehingga lecil kemungkinan orang yang tidak berhak dapat menguangkan cek yang diterima dari debitur untuk kepentingan pribadinnya.

\section{Fungsi yang Terkait}

Fungsi yang terkait dalam sistem penerimaan kas dari piutang adalah : ( Mulyadi , $2001: 487$ )

a. Fungsi Sekertariat

Dalam sistem penerimaan kas dari piutang, fungsi sekertariat bertanggung jawab dalam penerimaan cek dan surat pemberitahuan melalui pos dari para debitur perusahaan. Fungsi sekertariat bertugas untuk membuat daftar pemberitahuan atas dasar surat oemberitahuan yang diterima bersama cek dari para debitur.

b. Fungsi Penagihan

Jika perusahaan melakukan penagihan piutang langsung kepada debitur melalui penagihan perusahaan, fungsi penagihan bertanggung jawab untuk melakukan penagihan kepada para debitur perusahaan berdasarkan daftar piutang yang ditagih yang dibuat oleh fungsi akuntansi.

c. Fungsi Kas

Fungsi ini bertanggung jawab atas penerimaan cek dari fungsi sekertariat ( jika penerimaan kas dari piutang dilaksanakan melalui pos) atau dari fungsi penagihan (jika penerimaan kas dari piutang dilaksanakan melalui penagihan perusahaan ). Fungsi kas 
bertanggung jawab untuk menyetorkan kas yang diterima dari berbagai fungsi tersebut segera ke bank dalam jumlah penuh.

d. Fungsi Akuntansi

Fungsi akuntansi bertanggung jawab dalam pencatatan penerimaan kas dari piutang ke dalam jurnal penerimaan kas dan berkurangnya piutang ke dalam kartu piutang. Fungsi akuntansi berada ditangan bagian jurnal dan bagian piutang.

e. Fungsi Pemeriksa Intern

Dalam sistem penerimaan kas dan piutang, fungsi pemeriksaan intern bertanggung jawab dalam melaksanakan perhitungan kas yang ada di tangan fungsi kas secara periodik. Di samping itu, fungsi pemeriksa intrn bertanggung jawab dalam melakukan rekonsiliasi bank, untuk mengecek ketelitian catatan kas yang idselenggarakan oleh fungsi akuntansi.

\section{Dokumen yang Digunakan}

Dokumen yang digunkan dalam sistem penerimaan kas dari piutang adalah :( Mulyadi , $2001:$ 488)

a. Surat Pemberitahuan

Dokumen ini dibuat oleh debitur untuk memberitahu maksud pembayaran yang dilakukannya. Surat pemberitahuan biasanya berupa tembusan bukti kas keluar yang dibuat oleh debitur, yang disertakan dengan cek yang dikirimkan oleh debitur melalui penagihan perusahaan atau pos. Bagi perusahaan yang menerima kas dari piutang, surat pemberitahuan ini digunakan sebagai dokumen sumber dalam pencatatan berkurangnya piutang di dalam kartu piutang. Karena surat pemberitahuan biasanyya berupa tembusan bukti kas keluar.

b. Daftar Surat Pemberitahuan 
Daftar surat pemberitahuan, erupakam rekapitulasi penerimaan kas yang dibuat oleh fungsi sekertariat atau fungsi penagihan. Jika penerimaan kas dari piutang perusahaan dilaksanakan melalui pos, fungsi sekertariat bertugas membuka amplop surat memisahkan surat pemberitahuan dengan cek, dan membuat daftar surat pemberitahuan yang diterima setiap hari. Jika penerimaan kas dari piutang dilaksanakan melalui penagihan perusahaan, pembuatan daftar surat pemberitahuan dilakukan oleh fungsi penagihan.daftar surat penagihan dikirimkan ke fungsi kas untuk dipakai oleh fungsi akuntansi sebagai dokumen pendukung bukti setor bank dalam pencatatan penerimaan kas ke dalam jurnal penerimaan kas

c. Bukti Setor Bank

Dokumen ini dibuat oleh fungsi kas sebagai bukti penyetoran kas yang diterima dari piutang ke Bank. Bukti setor dibuat 3 lembar dan diserahkan oleh fungsi kas ke Bank, bersaamaan dengan penyetoran kas dari piutang ke Bank. Dua lembar tembusannya diminta kembali dari bank setelah ditandatangani dan dicap oleh Bank sebagai bukti penyetoran kas ke Bank. Bukti setoran Bank diserahkan oleh fungsi kas kepada fungsi akuntansi, dan dipakai pleh fungsi akuntansi sebagai dokumen sumber untuk pencatatan transaksi penerimaan kas dari piutang ke dalam jurnal penerimaan kas.

d. Kwitansi

Dokumen ini merupakan bukti penerimaan kas yang dibuat oleh perusahaan bagi para debitur yang telah melakukan pembayaran utang mereka. Kuitansi sebagai tanda penerimaan kas ini dibuat dalam sistem perbankan yang tidak mengembalikancancelled check kepada check issuer. Jika cancelled check dikembaliakn 
kepada check issuer kuitansi sebagi tanda penerimaan kas digantikan fungsinya oleh chancelled check.

\section{Unsur Pengendalian Intern}

Unsur pengendalia intern dalam sistem penerimaan kas dari piutang antara lain :( Mulyadi , 2001 : 491 )

\section{a. Organisasi}

$\varnothing$ Fungsi Kas harus terpisah dari Fungsi Penagihan dan Penerimaan Kas. Untuk menciptakan internal check fungsi penagihan yang bertanggung jawab untuk menagih dan menerima cek atau uang dari debitur harus dipisahkan dari fungsi penerimaan kas yang bertanggung jawab untuk melakukan enodrsement cek dan menyetorkan cek dan uang tunai hasil penagihan ke rekening giro perusahaan di bank.

$\varnothing$ Fungsi kas harus terpisah dari Fungsi Akuntansi. Fungsi akuntansi tidak boleh digabungkan dengan fungsi penyimpanan, untuk menghindari kemungkinan penggunaan catatan akuntansi untuk menutupi kecurangan yang dilakukan oleh karyawan. Jika fungsi akuntansi digabungkan dengan fungsi penerimaan kas, timbul kemungkinan fungsi penerimaan kas digabungkan dengan fungsi yang diterima dari debitur untuk kepentingan diri sendiri dan menutupi kecurangan tersebut dengan memanipulasi catatan piutang kepada debitur.

b. Sistem Otorisasi dan Prosedur Pencatatan

$\varnothing$ Debitur diminta untuk melakukan pembayaran dalam bentuk cek atas nama atau dengan cara pemindahbukuan (Giro Bilyet). Untuk menghindari debitur jatuh ke tangan pribadi karyawan, perusahana mewajibkan para debiturnya untuk melakukan 
pembayaran menggunakan cek atas nama perusahaan atau dengan bilyet giro,pembayaran yang dilakukan oleh debitur akan terjamin masuk kedalam rekening giro perusahaan.

$\varnothing$ Fungsi penagihan melakukan penagihan hanya atas dasr daftra piutang yang harus ditagih yang dibuat oleh fungsi akuntansi. Kegiatan fungsi penagihan harus dicek melalui sistem akuntansi. Fungsi penagihan hanya melakukan penagihan atas dasardaftar piutang yang telah jatuh tempo yang dibuat oleh fungsi akuntansi. Dengan demikian fungsi penagihan tidak mungkin melakukan penagihan piutang dari debitur, kemudian menggunakan uang hasil penagihan tersebut untuk kepentingan pribadinya dalam jangka waktu tertentu.

$\varnothing$ Pengkreditan rekeningpembantu piutang oleh fungsi akuntansi (bagian piutang) harus didasarkan atas surat pemberitahuan yang berasal dari debitur. Piutang adalah kekayaan perusahaan. Pengurangan terhadap piutang yang dicatat dalam catatan akuntansi harus didasarkan atas dokumen yang valid. Dokumen sumber yang dipakai sebagai dasar yang andal untuk mengurangi piutang adalah surat pemberitahuan yang diterima dari debitur bersamaan dengan cek.

c. Praktik yang Sehat

$\varnothing$ Hasil perhitungan kas direkam dalam berita acara penghitungan kas dan disetor penuh ke bank dengan segera. Jika perusahaan menerapkan kebijakan bahwa semua kas yang diterima disetor penuh ke bank dengan segera, maka kas yang ada di tangan bagian kasa pada suatu saat terdiri setoran dalam perjalanan. Secara periodik fungsi pemeriksaan bagian intern melakukan perhitungan kas dan hasil perhitungan tersebut direkam dalam 
suatu dokumen yang disebut berita acara perhitungan kas. Selesai dihitung, kas tersebut segera disetorkan ke bank dalam jumlah penuh.

$\varnothing$ Para penagih dan aksir harus diasurasikan. Manusi seringkali tergoda oleh situasi yang melingkupinya pada suatu saat tertentu. Untuk menghadapi kemungkinan kecurangan yang dilakukan oleh karyawan bagian kasa dan penagihan, karyawan yang langsung berhubungan dengan uang perusahaan lain perlu diasuransikan, sehingga jika karyawan yang diserahi tanggung jawab menjaga uang tersebut melakukan kecurangan, asuransi yang akan menaggung resiko kerugian yang timbul.

$\varnothing$ Kas dalam perjaanan ( baik yang ada ditangan bagian kasa maupun ditangan penagihan perusahaan ) garus diasuransikan. Untuk melindungi kekayaan perusahaan berupa uang yang dibawa oleh penagih, perusahaan dapat menutup asuransi cash in transit. Untuk melindungi kekayaan kas yang ada ditangan bagian kasa, perusahaan dapat menutup asuransi cash in safe. 


\section{Bagan Alir Dokumen}

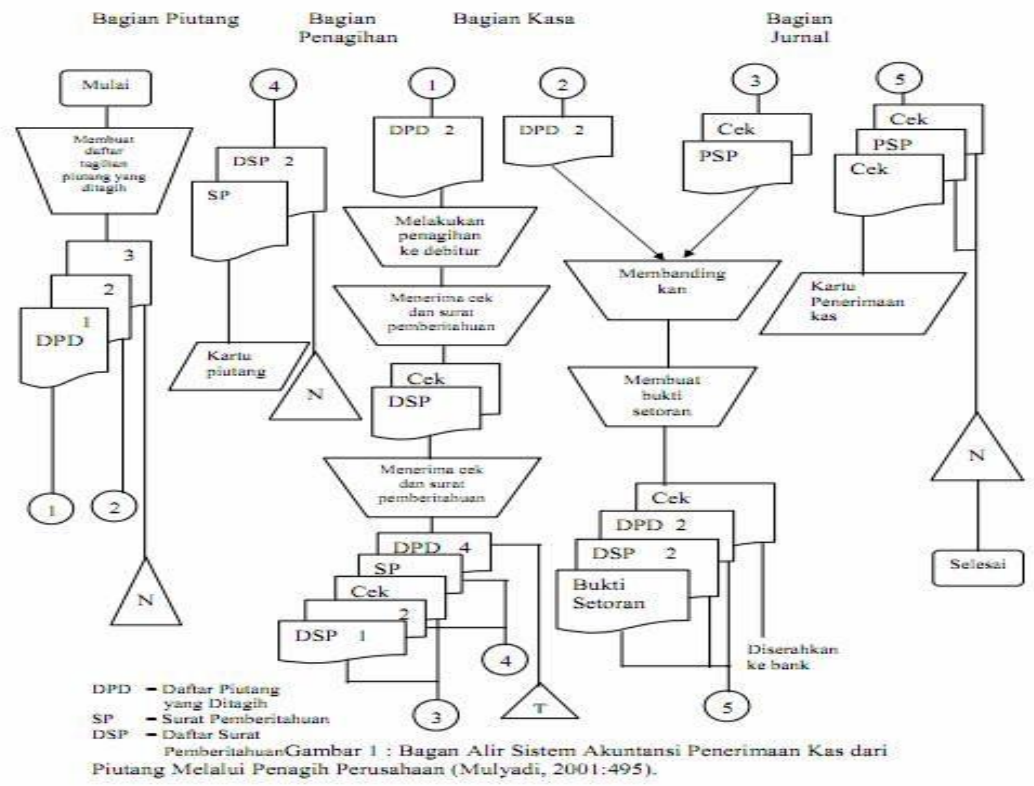

Gambar. Bagan Alir Sistem Penerimaan Kas dari Piutang( Mulyadi , 2001 : 495 )

\section{Jaringan Prosedur yang Membentuk Sistem Penjualan Kredit}

a. Prosedur order penjualan.

Fungsi penjualan menerima pesanan dan menambahkan informasi yang masih belum lengkap di surat orderan tersebut. Kemudian membuat surat order pengiriman dan mengirimkannya kepada berbagai fungsi yang lain.

b. Prosedur persetujuan kredit. 
Fungsi penjualan meminta persetujuan penjualan kredit kepada pembeli tertentu dari fungsi kredit.

c. Prosedur pengiriman.

Fungsi pengiriman mengirimkan barang yang telah diorder kepada pembeli.

d. Prosedur penagihan.

Fungsi penagihan membuat faktur penjualan dan mengirimkannya kepada pembeli.

e. Prosedur pencatatan piutang.

Fungsi akuntansi mencatat tembusan faktur penjualan ke dalam kartu piutang.

f. Prosedur distribusi penjualan.

Fungsi akuntansi mendistribusikan data penjualan menurut informasi yang diperlukan oleh manajemen.

g. Prosedur pencatatan harga pokok penjualan.

Fungsi akuntansi mencatat secara periodik total harga produk yang dijual dalam periode tertentu.

\section{Sistem Informasi Akuntansi Penjualan Kredit}

Dalam transaksi penjualan kredit, jika order dari pelanggan telah dipenuhi dengan pengiriman barang atau penyerahan jasa, untuk jangka waktu tertentu perusahaan memiliki piutang kepada pelanggannya. Dalam transaksi 
penjualan, tidak semua penjualan berhasil mendatangkan pendapatan bagi perusahaan. Adakalanya pembeli mengembalikan barang yang telah dibelinya kepada perusahaan, yang diakui sebagai retur penjualan. Sistem informasi akuntansi penjualan kredit merupakan sebuah subsistem dalam sebuah organisasi yang bertugas untuk mengubah data finansial menjadi informasi yang berguna bagi manajemen, kreditor, investor, dalam aktivitas pengambilan keputusan yang mereka lakukan karena kenaikan manfaat ekonomi selama satu periode akuntansi dalam bentuk pemasukan atau penambahan aktiva atau penurunan kewajiban yang mengakibatkan kenaikan ekuitas yang tidak berasal dari kontribusi penanaman modal.

Pengendalian Intern atas Sistem Informasi Akuntansi

a. Penjualan Kredit

Bentuk pengendalian internal yang sering diterapkan perusahaan adalah :

1. Organisasi

1.1. Fungsi penjualan terpisah dari fungsi kredit

1.2. Fungsi akuntansi terpisah dari funsi penjualan dan fungsi kredit

1.3. Fungsi akuntansi terpisah dari fungsi kas

2. Transaksi penjualan kredit harus dilakukan funsi penjualan, fungsi kredit, fungsi pengiriman, fungsi penagihan, dan fungsi akuntansi. Tidak ada transaksi yang dilakukan secara lengkap hanya oleh satu fungsi tersebut. 
3. Sistem otorisasi dan prosedur pencatatan

3.1. Penerimaan order dari pembeli diotorisasi fungsi penjualan dengan menggunakan formulir surat order pengiriman.

3.2. Persetujuan pemberian kredit diberikan fungsi kredit dengan membubuhkan tanda tangan pada credit copy (yang merupakan tembusan surat order pengiriman).

4. Pengiriman barang ke pelanggan diotorisasi fungsi pengiriman dengan menandatangani dan membubuhkan cap "sudah dikirim" pada copy surat order pengiriman.

5. Penetapan harga jual, syarat penjualan, syarat pengakuan barang, dan potongan penjualan ada di tangan direktur pemasarandengan penerbitan surat keputusan mengenai hal tersebut.

6. Pencatatan ke dalam catatan akuntansi harus didasar kan atas dokumen sumber yang dilampiri dengan dokumen pendukung yang lengkap.

7. Pencatatan ke dalam catatan akuntansi harus dilakukan oleh karyawan yang diberi wewenang untuk itu.

\section{Praktik yang sehat}

a. Perusahaan telah menggunakan formulir bernomor urut tercetak. 
b. Secara periodik fungsi akuntansi mengirim pernyataan piutang ke setiap debitur untuk menguji ketelitian catatan piutang yang diadakan fungsi tersebut.

c. Secara periodik diadakan rekonsiliasi kartu piutang dengan rekening kontrol piutang dalam buku besar.

d. Segala formulir dan catatan akuntansi harus digunakan dan dimanfaatkan dengan maksimal oleh tiap-tiap bagian dalam setiap transaksi, terutama digunakan sebagai dasar tindakan prosedur yang akan dilakukan selanjutnya.

\section{Sistem Informasi Akuntansi Penerimaan Kas atas Piutang}

Pengertian Piutang

Piutang adalah hak mengklaim kepada pihak lain (debitur) yang dikarenakan penjualan arang dagangan atau jasa atau hal lainnya. Menurut Mulyadi (1992:469), berdasarkan sumber terjadinya, piutang dapat dikelompokkan menjadi dua kelompok yaitu :

1. Piutang dagang/piutang usaha (Account Receivable). Piutang dagang adalah piutang yang timbul karena transaksi penjualan hasil produksi atau penyerahan barang dan jasa dalam rangka kegiatan usaha normal perusahaan.

2. Piutang non dagang (piutang lain-lain)

Piutang non dagang adalah piutang yang timbul dari transaksi selain penjualan barang dan jasa kepada pihak luar. Misalnya piutang yang timbul karena penjualan saham, piutang kepada karyawan, piutang klaim asuransi, piutang pengembalian pajak, piutang deviden dan bunga. 
Berdasarkan jangka waktunya, piutang dapat dikelompokkan menjadi dua, yaitu :

1. Piutang Lancar

Piutang lancar adalah piutang yang diharapkan dapat dicairkan menjadi uang dalam waktu satu tahun.

2. Piutang Jangka Panjang

Merupakan piutang yang tidak dapat dicairkan dalam jangka waktu satu tahun. Bagi kebanyakan perusahaan, piutang diperoleh dari bermacam-macam transaksi.Transaksi yang paling umum adalah penjualan barang dagangan atau jasa secara kredit.

Bagan Alur Penerimaan Kas dari Piutang (melalui Penagihan Perusahaan)

1. Fungsi piutang memberikan daftar piutang yang sudah waktunya ditagih ke fungsi penagihan.

2. Fungsi penagihan melakukan penagihan kepada debitur.

3. Fungsi penagihan menerima cek dan surat pemberitahuan dari debitur.

4. Fungsi penagihan menyerahkan cek ke fungsi kas.

5. Fungsi penagihan menyerahkan surat pemberitahuan kefungsi piutang untuk kepentingan posting ke dalam kartu piutang.

6. Fungsi kas mengirim kwitansi sebagai tanda penerimaan kas kepada debitur.

7. Fungsi kas menyetorkan cek ke bank dan bank perusahaan melakukan clearing atas cek tersebut ke bank debitur. 
Pengendalian Intern atas Sistem Informasi Akuntansi Penerimaan Kas atas Piutang

Bentuk pengendalian internal penerimaan kas untuk piutang yang sering diterapkan perusahaan adalah :

1. Organisasi

a. Fungsi penagihan telah terpisah dari fungsi penerimaan kas dan fungsi akuntansi.

b.Fungsi penerimaan kas telah terpisah dari fungsi akuntansi.

2. Sistem otorisasi dan prosedur pencatatan

a. Debitur diminta untuk melakukan pembayaran dalam bentuk cek atau giro atas nama.

b. Fungsi penagihan telah melakukan penagihan hanya atas dasar daftar piutang yang harus ditagih yang terdapat didalam laporan piutang yang dibuat oleh bagian keuangan.

3. Praktik yang sehat

a. Hasil penghitungan kas harus direkam dalam berita penghitungan kas dan disetor penuh ke bank dengan segera.

b. Para penagih dan kasir harus diasuransikan.

c. Kas dalam perjalanan (baik yang ditangan bagian kasir maupun di tangan bagian penagihan) harus diasuransikan. 


\section{Siklus Pendapatan}

Siklus pendapatan adalah rangkaian aktivitas bisnis dan kegiatan pemrosesan informasi terkait yang terus berulang dengan menyediakan barang dan jasa ke para pelanggan dan menagih kas sebagai pembayaran dari penjualan-penjualan tersebut. Infromasi mengenai berbagai aktivitas siklus pendapatan juga mengalir ke siklus akuntansi lainnya (melalui database pusat). Contohnya, siklus pengeluaran dan produksi menggunakan informasi mengenai transaksi penjualan untuk memulai pembelian atau produksi persediaan tambahan untuk memenuhi permintaan. Siklus sumber daya manusia atau penggajian menggunakan informasi mengenai penjualan untuk menghitung komisi penjualan dan berbagai bonus.

Fungsi buku besar dan pelaporan menggunakan informasi yang dihasilkan oleh siklus pendapatan untuk mempersiapkan laporan keuangan dan kinerja. Berikut ini disajikan alur aktivitas siklus pendapatan dan hubungan dengan siklus lainnya dalam diagram konteks siklus pendapatan di bawah ini, 


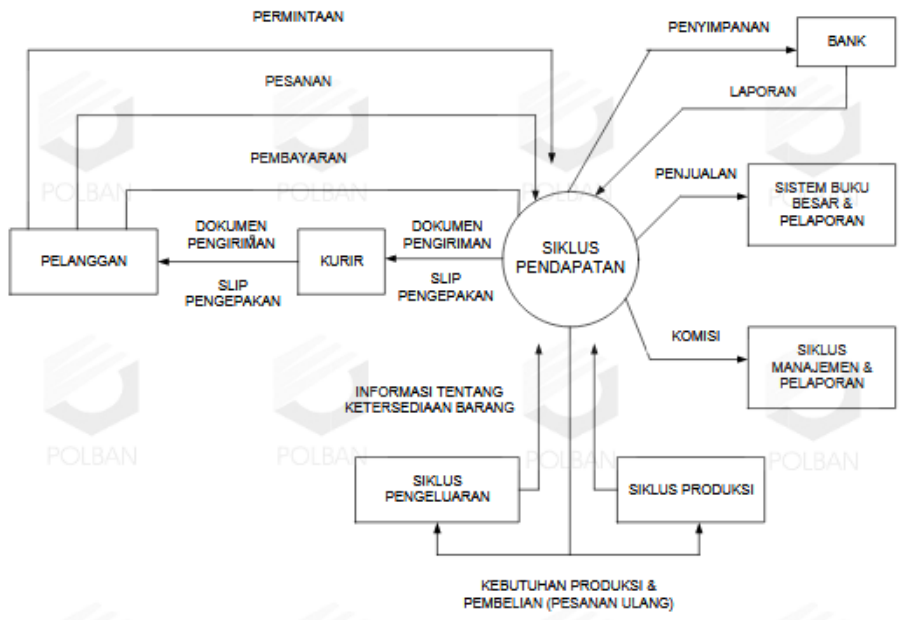

Sumber : Romney And Steinbart (2005:6) dalam Accounting Information Systems

Aktivitas siklus pendapatan dimulai dengan penerimaa pesanan dari pelanggan. Departemen pesanan penjualan yang bertanggung jawab pada wakil direktur utama bagian pemasaran Lihat Gambar melakukan proses entri pesanan penjualan.

Berikut diagram arus data dari siklus pendapatan yang menggambarkan empat aktivitas utama siklus pendapatan, yaitu Entri Pesanan Penjualan, Pengiriman, Penagihan Piutang Usaha dan Penagihan Kas. 


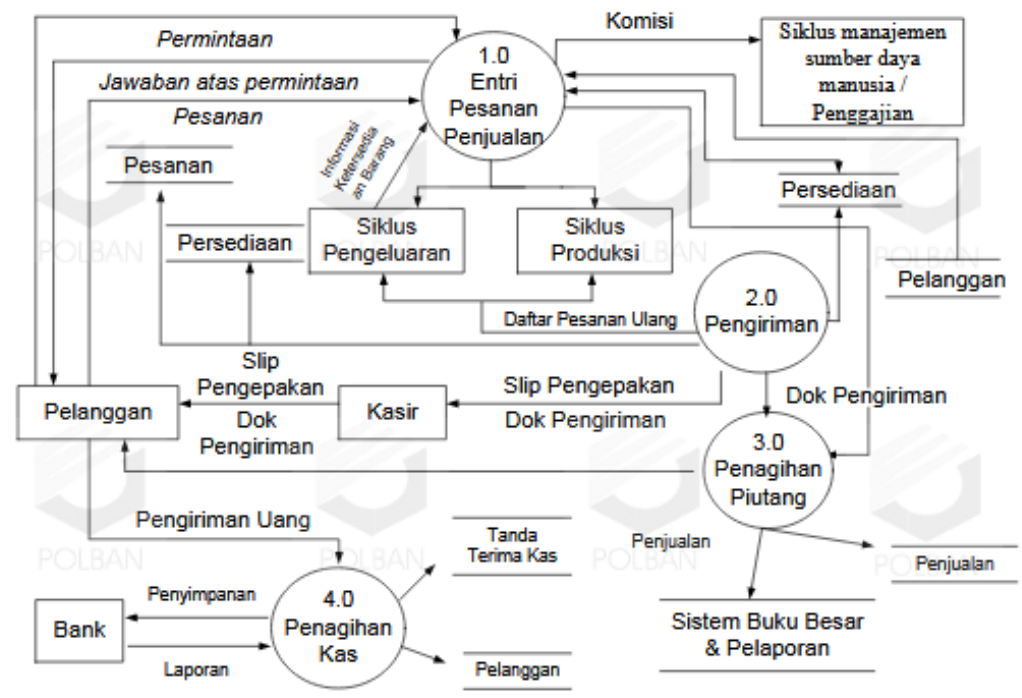

Sumber : Romney And Steinbart (2005:8) dalam Accounting Information Systems 2 


\section{BAGIAN 5}

\section{SISTEM AKUNTANSI PEMBELIAN, PENGELUARAN KAS}

\section{TUJUAN INSTRUKSIONAL UMUM :}

Mampu memahami dan Mengaplikasikan (membuat) Siklus Pengeluaran : Pembelian dan Pengeluaran Kas

\section{SUB BAGIAN :}

\subsection{Sistem Akutansi Pembelian}

Sistem akuntansi pembelian digunakan dalam perusahaan untuk pengadaan barang yangdiperlukan oleh perusahaan. Transaksi pembelian digolongkan menjadi 2, yaitu pembelian lokal danimport. Pembelian lokal adalah pembelian dari pemasok dalam negeri sedangkan impor adalah pembeliandari pemasok luar negeri. Beberapa fungsi yang terkait dalam sistem akuntansi pembelian, antara lain :

1. Fungsi gudang, bertanggungjawab mengajukan permintaan pembelian sesuai dengan posisi persediaan yang ada di gudang dan untuk menyimpan barang yang diterima oleh fungsi penerimaan,

2. Fungsi pembelian, bertanggung jawab untuk memeroleh informasi mengenai harga barang, menentukan pemasok dan mengeluarkan order, 
3. Fungsi penerimaan, bertanggungjawab melakukan pemeriksaanterhadap jenis, mutu, dan kuantitas barang yang diterima dari pemasok,

4. Fungsi akuntansi, terdapat 2 fungsi yaitu fungsi pencatat uang dan fungsi pencatat persediaan yang masing-masingmemiliki tanggung ajwab yang berbeda, fungsi pencatat uang bertanggung jawab mencatat transaksi pembelian ke register bukti kas keluar dan untuk fungsi pencatat persediaan bertanggung jawab untuk mencatatharga pokok persediaan ke dalam kartu persediaan.

5. Secara garis besar transaksi pembelian mencakup beberapa prosedur, yakni :

a. Fungsi gudang mengajukan permintaan pembelian ke fungsi pembelian. Dasar dari permintaannyaadalah saldo persediaan suatu barang, bila saldo mendekati jumlah minimum, maka bagian gudang segeramembuat permintaan pembelian.

b. Fungsi pembelian meminta penawaran harga dari berbagai pemasok dan melakukan pemilihan pemasok, kemudian membuat order pembelian kepada pemasok yang dipilih. Order pembelian dibuatrangkap empat (4), lembar pertama untuk pemasok, lembar kedua untuk gudang, lembar ketiga untuk voucher, lembar keempat untuk arsip.

c. Fungsi penerimaan memeriksa dan menerima barang yang dikirim oleh pemasok, menyerahkan barangyang diteima 
kepada fungsi gudang untuk disimpan, dan melaporakan penerimaan barang kepada fungsiakuntansi.

d. Fungsi akuntansi menerima faktur tagihan dari pemasok dan atas dasar faktur dari pemasok tersebut,fungi akuntansi mencatat kewajiban yang timbul dari transaksi pembelian.

\section{JARINGAN PROSEDUR YANG MEMBENTUK SISTEM AKUNTANSI PEMBELAN}

Jaringan Prosedur yang membentuk sistem akuntansi pembelian adalah :

a. Prosedur permintaan pembelian: Fungsi gudang mengajukan permintaan pembelian dalamformulir surat permintaan pembelian kepada fungsi pembelian Prosedur permintaan penawaran harga dan pemilihan pemasok: Fungsi pembelian mengirimkansurat permintaan penaaran harga kepaa para pemasok untuk memeroleh informasi menganai harga barang dan berbagai syarat pembelian yang lai

b. Prosedur order pembelian: Fungsi pembelian mengirim surat order pembelian kepada pemasokyang dipilih dan memberitahukan kepada unit-unit organisasi lain dalam perusahaan mengenai order pembelian yang sudah dikeluarkan perusahaan.

c. Prosedur penerimaan barang: Fungsi penerimaan melakukan pemeriksaan mengenai jenis,kuantitas, dan mutu barang yang diterima lalu membuat laporan penerimaan barang.

d. Prosedur pencatatan utang: Fungsi akuntansi memeriksa dokumendokumen yang berhubungan dengan pembelian dan faktur dari pemasok dan mengarsip dokumen dan mencatatnya sebagai utang. 
e. Prosedur distribusi pembelian: Meliputi distibusi rekening yang didebit dari transaksi pembelianuntuk kepentingan pembuatan laporan manajemen.

\section{INFORMASI YANG DIPERLUKAN OLEH MANAJEMENI}

Informasi yang diperlukan oleh manajemen adalah :

a. Jenis pesediaan yang telah mencapai titik pemesanan kembali.

b. Order pembelian yang dikirim kepada pemasok

c. Order pembelian yang telah dipenuhi oleh pemasok

d. Total saldo utang dagang pada tanggal tertentu

e. Saldo utang dagang kepada pemasok tertentu

f. Tambahan kuantitas dan harga pokok persediaan dari pembelian

g. Daftar harga barang dagangan, atau daftar bahan baku yang relatif penting

h. Kontrak pembelian dan realisasinya

\section{DOKUMENYANG DIGUNAKAN}

Dokumen yang digunakan adalah:

a. Surat permintaan pembelian

b. Surat permintaan penawaran harga 

c. Surat order pembelian
d. Laporan penerimaan barang
e. Surat perubahan order
f. Bukti kas keluar

\section{CATATAN AKUNTANSI YANG DIGUNAKAN}

Catatan akuntansi yang digunakan adalah :
a. Register buku kas keluar
b. Jurnal pembelian (Register Pembelian)
c. Kartu utang
d. Kartu persediaan

\section{UNSUR PENGENDALAN INTERN}

Unsur pengendalain intern dirancang untuk mencapai tujuan pokok pengendalain internakuntansi, yaitu menjaga kekayaan (persediaan) dan kewajiban perusahaan (utang dagang atau bukti kaskeluar yang akan dibayar), menjamin ketelitian dan keandalan data akuntansi (utang dan persediaan).Unsur pokok sistem pengendalian intern terdiri dari organisasi, sistem otorisasi dan prosedur pencatatan,dan praktik yang sehat.

1. Organisasi

a. Fungsi pembelian harus terpisah dari fungsi penerimaan. 
b. Fungsi pembelian harus terpisah dari fungsi akuntansi.

c. Fungsi penerimaan harus terpisah dari fungsi penyimpanan barang.

d. Transaksi pembelian harus dilaksanakan oleh fungsi gudang, fungsi pembelian, fungsi penerimaan dan fungsi akuntansi.

e. Tidak ada transaksi pembelian yang dilaksanakansecara lengkap oleh hanya satu bagian dari fungsi tersebut.

\section{Sistem otorisasi dan prosedur pencatatan}

a. Surat permintaan pembelian diotorisasi oleh fungsi gudang, untuk barang yang disimandalam gudang, oleh atau fungsi pemakai barangm untuk barang yang langsung pakai.

b. Surat order pembelian diotorisasi oleh fungsi pembelian atau pejabat yang lebih tinggi.

c. Laporan penerimaan barang diotorisasi oleh fungsi penerimaan barang.

d. Bukti kas keluar diotorisasi oleh fungsi akuntansi atau pejabat yang lebih tinggi.

e. Penctatan terjadinya utang didasarkan pada bukti kas keluar yang didukung dengan suratorder pembelian, laporan penerimaan barang, dan faktur dari pemasok . 
f. Pencatatan ke dalam kartu utang dengan register bukti kas keluar diotorisasi oleh fungsiakuntansi

\section{Praktik yang sehat}

a. Surat permintaan pembelian bernomor urut tercetak dan pemakaiannyadipertanggungjawabkan oleh fungsi gudang.

b. Surat order pembelian bernomor urut tercetak dan pemakaiannya dipertanggungjawabkanoleh fungsi pembelian.

c. Laporan penerimaan barang bernomor urut tercetak dan pemakaiannyadipertanggungjawabkan oleh fungsi penerimaan.

d. Pemasok dipilih berdasarkan jawaban penawaran harga bersaing dari berbagai pemasok.

e. Barang hanya diperiksa dan diterima oleh fungsi penerimaan jika fungsi ini telahmenerima tembusan surat order pembelian dari fungsi pembelian.

f. Fungsi penerimaan melakukan pemeriksaan barang yang diterima dari pemasok dengancara menghitung dan mengisnpeksi barang tersebut dan membandingkannya dengantembusan surat order pembelian

Prosedur Penerimaan Penawaran Harga Pemilihan Pemasok. 
Perusahaan menentukan jenjang wewenang dalam menentukan pemilihan pemasok sehingga sistem akuntansi pembelian dibagi menjadi sebagai berikut :

1. Sistem akuntansi pembelian dengan pengadaan langsung. Dalam sistem akuntansi pembelian ini, pemasok dipilih langsung oleh fungsi pembelian, tanpa melalui penawaran harga.

2. Sistem akuntansi pembelian dengan penunjukkan langsung.

Dalam sistem akuntansi pembelian ini, pemilihan pemasok dilakukan oleh fungsi pembelian, dengan terlebih dahulu dilakukan pengiriman permintaan penawaran harga kepada paling sedikit tiga pemasok dan di dasarkan pada pertimbangan harga penawaran dari para pemasok tersebut.

3. Sistem akuntansi pembelian dengan lelang.

Dalam sistem akuntansi pembelian ini, pemiliahan pemasok dilakukan panitia lelang yang dibentuk, melalui lelang yang diikut oleh pemasok yang jumlahnya terbatas.

4. Sistem akuntansi dengan pengadaan langsung.

\section{Prosedur order pembelian.}

Dalam prosedur ini, fungsi pembelian mengirim surat order pembelian kepada pemasok yang dipih dan memberitahukan kepada unit-unit organisasi lain dalam perusahaan ( misalnya fungsi penerimaan, fungsi meminta barang, dan fungsi pencatat 
utang ) mengenai order pembelian yang sudah dikeluarkan oleh perusahaan.

\section{Prosedur penerimaan barang.}

Dalam prosedur ini fungsi penerimaan melakukan pemeriksaan mengenai jenis, kuantitas, dan mutu barang yang diterima dari pemasok, dan kemudian membuat laporan penerimaan barang untuk menyatakan perimaan barang dari pemasok tersebut.

\section{Prosedur pencatat utang.}

Dalam prosedur ini fungsi akuntansi memeriksa dokumendokumen yang berhubungan dengan pembelian ( surat order pembelian, laporan penerimaan barang, dan faktur dari pemasok ) dan menyelenggarakan pencatatan utang atau mengarsipkan dokumen sumber sebagai catatan utang.

\section{Prosedur distribusi pembelian.}

Prosedur ini meliputi distribusi rekening yang didebit dari transaksi pembelian untuk kepentingan pembuatan laporan manajemen. Informasi yang diperlukan oleh manajemen dari sistem akuntansi pembelian adalah :

1. Jenis persediaan yang telah mencapai titik pemesanan kembali ( reorder point ).

2. Order pembelian yang telah dikirim kepada pemasok.

3. Order pembelian yang telah dipenuhi oleh pemasok.

4. Total saldo utang dagang pada tanggal tertentu.

5. Saldo utang dagang kepada pemasok tertentu. 
6. Tambahan kuantitas dan harga pokok persediaan dari pembelian.

Dokumen yang digunakan dalam sistem akuntansi pembelian adalah :

1. Surat permintaan pembelian.

2. Surat permintaan penawaran harga.

3. Surat order pembelian.

4. Laporan penerimaan barang.

5. Surat perubahan order.

6. Bukti kas keluar.

7. Surat permintaan pembelian.

Dokumen ini merupakan formulir yang di isi oleh fungsi gudang atau fungsi pemakai barang untuk meminta fungsi pembelian melakukan pembelian barang dengan sejenis, jumlah, dan mutu seperti yang terdapat dalam surat tersebut.

8. Memesan bahan baku, perlengkapan dan jasa

9. Penerimaan

10. Menyetujui faktur pemasok

11. Pengeluaran kas 


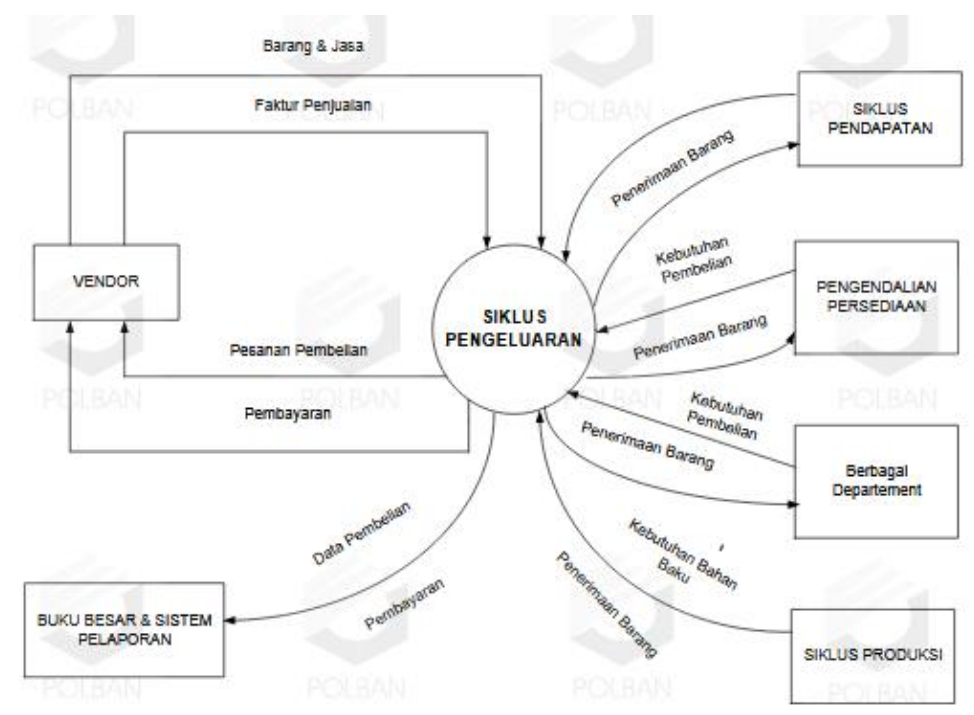

Sumber: Romney And Steinbart (2005:77) dalam Accounting Information Systems.

\subsection{SIKLUS PENGELUARAN}

Keberadaan sistem pengeluaran kas dapat mendukung pencapaian tujuan dari perusahaan. Sistem tersebut membuat perusahaan lebih mudah dalam mengelola hal- hal yang berkaitan dengan besarnya pengeluaran kas yang terjadi yang pada akhirnya dapat berpengaruh terhadap laba yang diterima perusahaan. Laba tersebut tentunya dapat bermanfaat bagi kelangsungan perusahaan dan pihak pihak yang berkepentingan seperti manajer, karyawan, investor, bank dan lain sebagainya.

Sistem akuntansi pengeluaran kas terdiri dari dua sistem pokok yaitu sistem akuntansi pengeluaran kas dengan cek dan sistem pengeluaran kas dengan uang tunai melalui sistem dana kas kecil (Mulyadi, 2001: 509). Sistem akuntansi pengeluaran kas ini 
terdiri dari dokumen, catatan akuntansi yang digunakan, fungsi terkait, jaringan prosedur yang membentuk sistem akuntansi pengeluaran kas.

\section{A. SISTEM AKUNTANSI PENGELUARAN KAS DENGAN CEK}

Sistem akuntansi pengeluaran kas dengan menggunakan cek biasanya ditujukan untuk pengeluaran yang jumlah nominalnya besar. Pengeluaran kas dengan sistem cek ini mempunyai beberapa kebaikan ditinjau dari pengendalian intern, diantaranya :

a. Pengeluaran kas dengan cek dapat menjamin bahwa cek yang dikeluarkan diterima oleh pihak yang namanya tercantum dalam formulir cek

b. Transaksi pengeluaran kas dapat direkam oleh bank sebagai pihak luar yang kemudian pihak bank akan mengirimkan rekening koran kepada perusahaan. Rekening koran ini dapat digunakan perusahaan untuk mengecek ketelitian catatan transaksi pengeluaran kas.

c. Pengeluaran kas dengan cek juga memberikan manfaat tambahan yaitu adanyacancelled chek yang merupakan tanda terima kas dari pihak yang menerima pembayaran. Dengan penggunaan cek dalam pengeluaran kas, check issuer secara otomatis menerima tanda terima kas dari pihak yang menerima pembayaran.

Berdasarkan uraian di atas maka pengeluaran kas dengan menggunakan cek sangat berguna sekali bagi perusahaan karena dapat ditelusur penggunaan cek tersebut. Penelusuran tersebut dapat dilakukan melalui rekonsiliasi bank.

Berikut dokumen, catatan, fungsi terkait, jaringan prosedur dan unsur pengendalian intern yang membentuk sistem akuntansi pengeluaran kas dengan cek : 


\section{Dokumen yang digunakan}

Dokumen yang digunakan dalam sistem akuntansi pengeluaran kas dengan cek adalah :

1. Bukti Kas Keluar (BKK)

Dokumen ini berfungsi sebagai perintah pengeluaran kas kepada bagian kasa sebesar yang tercantum dalam dokumen tersebut. BKK ini juga dikirimkan kepada kreditur sebagai surat pemberitahuan dan sebagai dokumen sumber bagi pencatatan berkurangnya utang.

2. Cek

Cek merupakan dokumen perintah kepada bank untuk melakukan pembayaran sejumlah uang kepada pihak/orang yang tercatum dalam dokumen tersebut.

3. Permintaan Cek

Dokumen ini berfungsi sebagai permintaan dari fungsi yang memerlukan pengeluaran kas kepada fungsi akuntansi untuk membuat bukti kas keluar.

\section{Catatan Akuntansi yang Digunakan}

Catatan akuntansi yang digunakan dalam sistem akuntansi pengeluaran kas dengan cek adalah :

a. Jurnal Pengeluaran Kas

Catatan ini digunakan untuk mencatat segala pengeluran kas yang dilakukan oleh perusahaan. Dokumen sumber yang dipakai sebagai dasar pencatatan dalam jurnal ini adalah faktur dari pemasok yang telah dicap "lunas" oleh fungsi kas. 


\section{b. Register Cek}

Register cek ini digunakan untuk mencatat cek-cek perusahaan yang dikeluarkan untuk pembayaran para kreditur perusahaan atau pihak lain.

\section{Fungsi Terkait}

Fungsi yang terkait dengan sistem akuntansi pengeluaran kas dengan cek adalah :

a. Fungsi Yang Memerlukan Pengeluaran Kas

Fungsi ini biasanya mengajukam cek kepada fungsi akuntansi (bagian utang) jika memerlukan pengeluaran kas untuk suatu kepentingan perusahaan. Permintaan cek ini harus mendapatkan persetujuan dari kepala fungsi yang bersangkutan. Jika perusahaan menggunakan voucher payable system maka bagian utang membuat bukti kas keluar untuk memungkinkan bagian kasa mengisi cek sejumlah permintaan yang diajukan oleh fungsi yang memerlukan pengeluaran kas.

b. Fungsi Kasa

Fungsi ini bertanggung jawab dalam mengisis cek, memintakan otorisasi cek dan mengirimkan cek kepada kreditur via pos atau membayarkan secara langsung kepada kreditur atau melakukan pemindahbukuan melalui jasa perbankan.

c. Fungsi Akuntansi

Fungsi ini bertanggung jawab atas pencatatan pengeluaran kas yang menyangkut biaya dan sediaan, pencatatan transaksi pengeluaran kas dalam jurnal pengeluaran kas atau register cek, dan pembuatan BKK yang memberikan otorisasi kepada fungsi 
kasa dalam mengeluarkan cek sebesar yang tercantum dalam dokuemen tersebut.

Flowchart Pengeluaran Kas dengan Cek

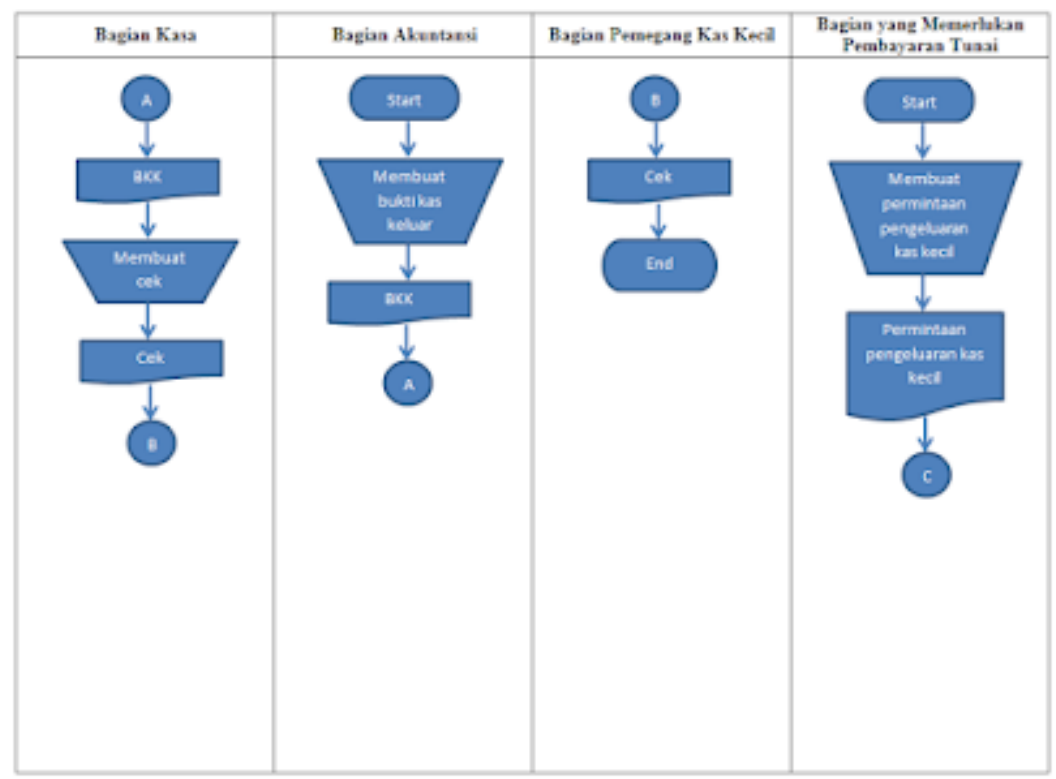



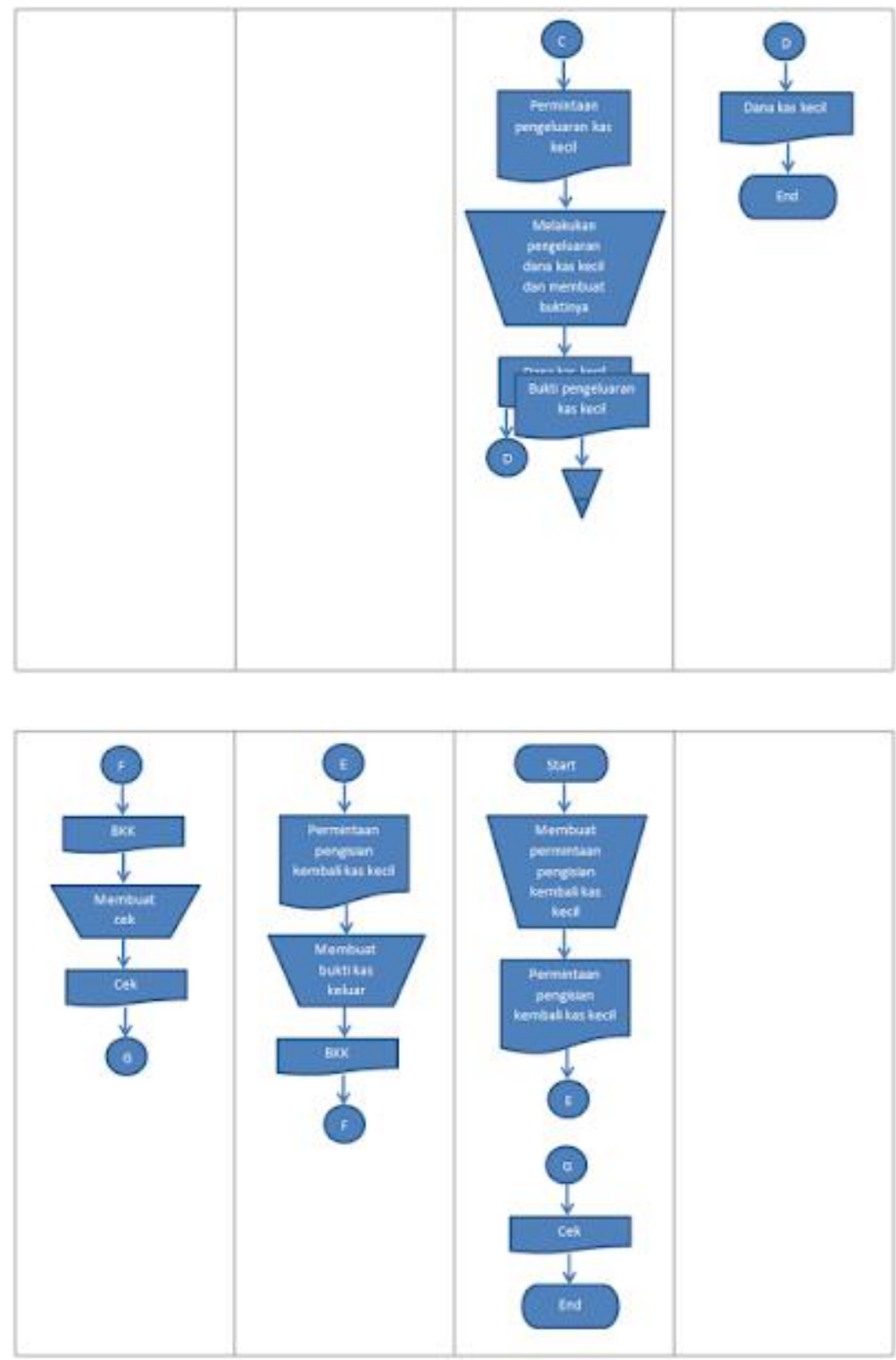

121 


\section{SISTEM AKUNTANSI PENGELUARAN KAS DENGAN UANG TUNAI MELALUI SISTEM DANA KAS KECIL}

Sistem dana kas kecil digunakan perusahaan jika terjadi pengeluaran dengan nominal kecil. Sistem ini dilakukan dengan dua cara yaitu sistem saldo berfluktuasi (fluctuating fund balance system) dan sistem saldo tetap (imprest system).

\section{UNIT ORGANISASI YANG TERKAIT DALAM SISTEM PENGELUARAN KAS DENGAN UANG TUNAI MELALUI SISTEM DANA KAS KECIL}

Unit Organisasi yang terkait dalam Sistem Pengeluaran Kas dengan Uang Tunai melalui Sistem Dana Kas Kecil adalah:

a. Fungsi kas

Fungsi ini bertanggungjawab dalam mengisi cek, memintakan otorisasi cek, dan menyerahkan cek kepada pemegang dana kas kecil pada saat pembentukan dan pengisian kembali dana kas kecil.

b. Fungsi akuntansi

Fungsi ini bertanggungjawab atas pencatatan pengeluaran kas kecil yang menyangkut biaya dan persediaan, pencatatan transaksi pembentukan dan pengisian kembali dana kas kecil, pencatatan pengeluaran dana kas kecil dalam jurnal pengeluaran dana kas kecil dan pembuatan BKK yang memberikan otorisasi kepada fungsi kas dalam mengeluarkan cek sebesar yang tercantum dalam dokumen tersebut.

c. Fungsi pemegang kas kecil 
Fungsi ini bertanggungjawab atas penyimpanan dana kas kecil, pengeluaran dana kas kecil sesuai dengan otorisasi dari pejabat tertentu yang ditunjuk, dan permintaan kembali dana kas kecil.

d. Fungsi yang memerlukan pembayaran tunai

Fungsi ini mengajukan permintaan untuk melakukan pembayaran tunai yang menggunakan dana kas kecil.

e. Fungsi pemeriksa intern

Fungsi ini bertanggungjawab atas penghitungan dana kas kecil secara periodic dan pencocokan hasil penghitungan dengan catatan kas.

\section{DOKUMEN YANG DIGUNAKAN DALAM SISTEM PENGELUARAN KAS DENGAN UANG TUNAI MELALUI SISTEM KAS KECIL}

Dokumen yang digunakan dalam Sistem Pengeluaran Kas dengan Uang Tunai melalui Sistem Kas Kecil adalah:

a. BKK

Dokumen ini berfungsi sebagai perintah pengeluaran kas dari fungsi akuntansi kepada fungsi kas sebesar yang tercantum. Dokumen ini diperlukan saat pembentukan dana kas kecil dan pada saat pengisian kembali dana kas kecil.

b. Cek

Cek merupakan dokumen perintah kepada bank untuk melakukan pembayaran sejumlah uang kepada pihak / orang yang tercatum dalam dokumen tersebut.

c. Permintaan pengeluaran kas kecil 
Dokumen ini digunakan oleh pemakai dana kas kecil untuk meminta uang ke pemegang dana kas kecil. Dokumen ini berfungsi sebagai bukti telah dikeluarkannya dana kas kecil bagi pemegang dana kas kecil dan selanjutnya diarsip menurut nama pemakai dana kas kecil.

d. Bukti pengeluaran kas kecil

Dokumen ini dibuat oleh pemakai dana kas kecil untuk mempertanggungjawabkan pemakaian dana kas kecil. Dalam sistem saldo tetap, bukti dokumen ini dilampiri dengan dokumen pendukungnya dan disimpan dalam arsip sementara oleh pemegang dana kas kecil untuk keperluan pengisian kembali, sedangkan dalam sistem saldo berfluktuasi, dokumen ini dilampiri dengan dokumen pendukungnya dan diserahkan oleh pemegang dana kas kecil kepada fungsi akuntansi untuk dicatat dalam jurnal pengeluaran dana kas kecil.

e. Permintaan pengisian kembali kas kecil

Dokumen ini dibuat oelh pemegang dana kas kecil untuk meminta kepada bagian utang agar membuat BKK untuk pengisian kembali dana kas kecil. Dalam sistem saldo tetap maka jumlah pengisian kembali dana kas kecil sebesar jumlah uang tunai yang dikeluarkan sesuai yang tercantum dalam bukti pengeluaran kas kecil yang dikumpulkan dalam arsip pemegang dana kas kecil. Dalam sistem saldo berfluktuasi, pengisian kembali didasarkan sesuaikebutuhan pengeluran uang tunai yang diperkirakan oleh pemegang dana kas kecil. 


\section{CATATAN AKUNTANSI YANG DIGUNAKAN DALAM SISTEM PENGELUARAN KAS DENGAN UANG TUNAI MELALUI SISTEM KAS KECIL}

Catatan akuntansi yang digunakan dalam sistem dana kas kecil diantaranya :

a. Jurnal pengeluaran kas

Jurnal ini digunakan untuk mencatat pengeluaran kas dalam pembentukan dana kas kecil dan dalam pengisian kembali kas kecil.

b. Register Cek

Catatan ini digunakan untuk mencatat cek perusahaan yang dikeluarkan untuk pembentukan dan pengisian kembali dana kas kecil.

c. Jurnal pengeluaran kas kecil

Jurnal ini merupakan jurnal khusus untuk mencatat pengeluaran dana kas kecil sekaligus sebagai alat distribusi pendebitan yang timbul sebagai akibat pengeluaran dana kas kecil. Jurnal ini digunakan hanya dalam sistem saldo berfluktuasi. 


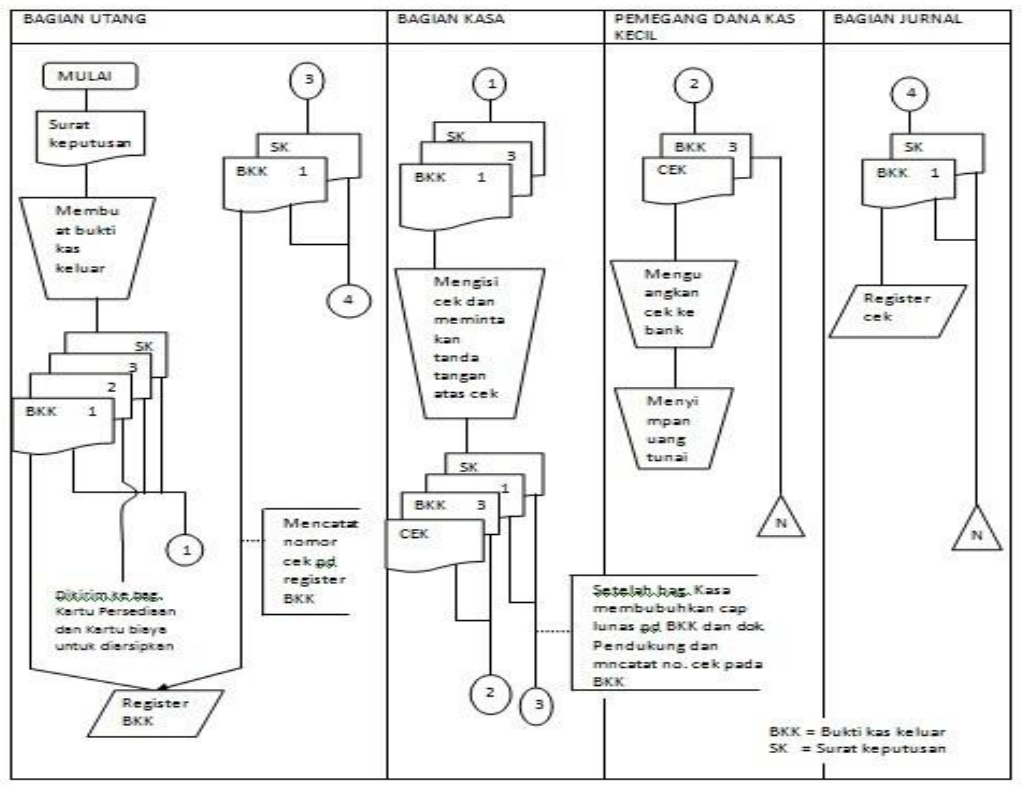

a. FLOWCHART SISTEM PENGELUARAN DANA KAS KECIL DENGAN IMPREST SYSTEM 
2.a. prosedur pengeluaran dana kas kecil dengan imprest system

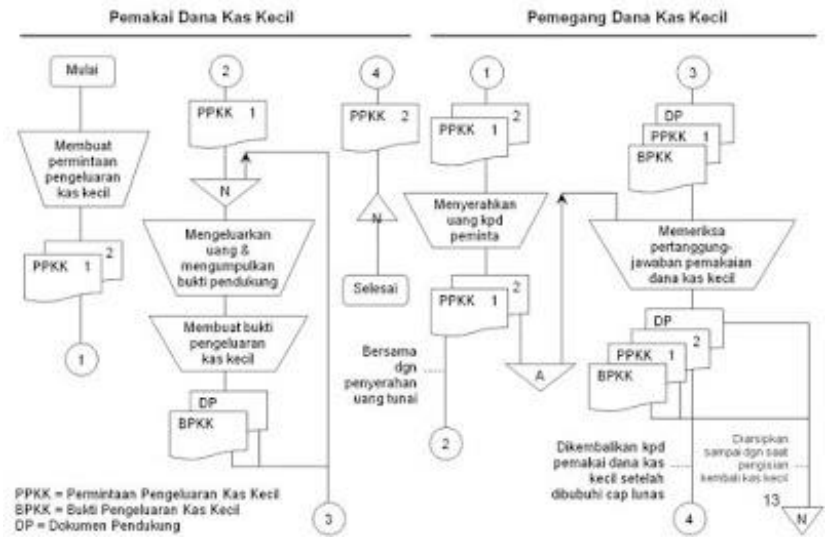

\section{b. FLOWCHART SISTEM PENGELUARAN DANA KAS KECIL DENGAN}

\section{FLUCTUATING-FUND-BALANCE SYSTEM}

2.b. prosedur pengeluaran dana kas kecil dengan fluctuating-fund-balance system

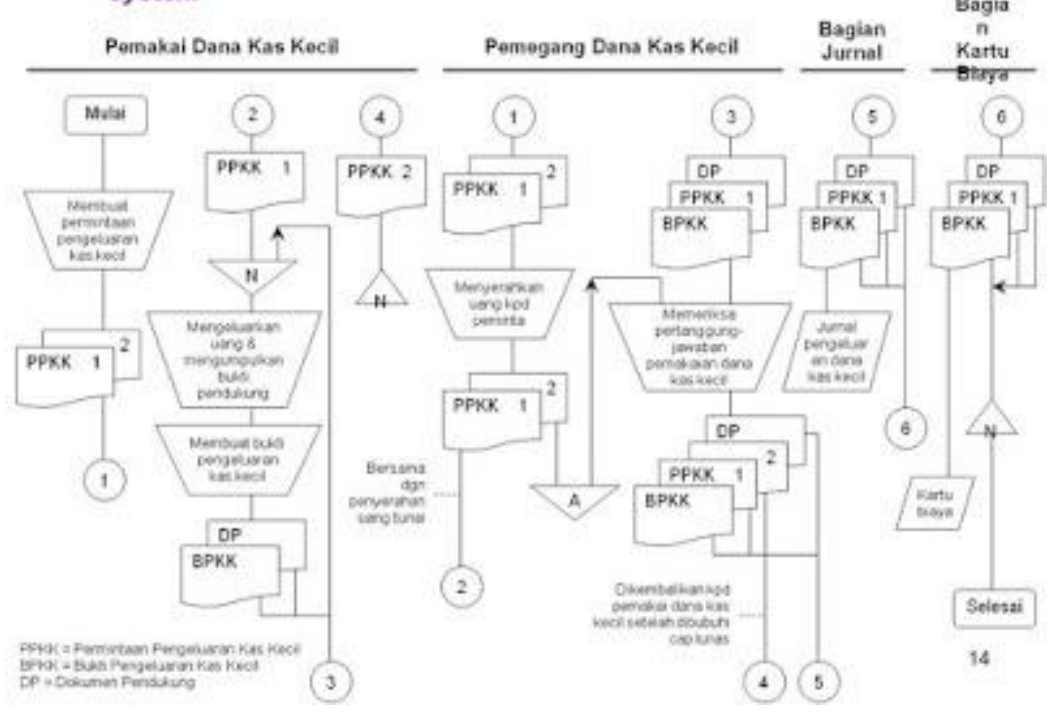




\section{TUJUAN INSTRUKSIONAL UMUM :}

Mampu memahami dan Mengaplikasikan (membuat) Siklus Manajemen Sumber Daya Manusia

\section{SUB BAGIAN :}

\subsection{Sistem informasi siklus MSDM/ Penggajian}

Gaji dan upah merupakan bagian dari kompensasikompensasi yang paling besar yang diberikan perusahaan sebagai balas jasa kepada karyawannya. Dan bagi karyawan ini merupakan nilai hak dari prestasi mereka, juga sebagai motivator dalam bekerja.

Sedangkan bagi perusahaan jasa, gaji dan upah merupakan komponen biaya yang mempunyai dampak besar dalam mempengaruhi laba, sehingga harus terus menerus diawasi pengelolaannya.

Untuk dapat memahami lebih lanjut arti dari gaji dan upah perlu diketahui terlebih dahulu beberapa defenisi dari gaji dan upah menurut pendapat para ahli di bawah ini. 
Niswonger (1999:446) mengemukakan bahwa:

Istilah gaji (salary) biasanya digunakan untuk pembayaran atas jasa manajerial, administratif, dan jasa-jasa yang sama. Tarif gaji biasanya diekspresikan dalam periode bulanan. Istilah upah (wages) biasanya digunakan untuk pembayaran kepada karyawan lapangan (pekerja kasar) baik yang terdidik maupun tidak terdidik. Tarif upah biasanya diekspresikan secara mingguan atau perjam.

Sementara Mulyadi (2001:373) mengemukakan bahwa:

Gaji umumnya merupakan pembayaran atas penyerahan jasa yang dilakukan oleh karyawan yang mempunyai jenjang jabatan manajer, sedangkan upah umumnya merupakan pembayaran atas penyeraha jasa yang dilakukan oleh karyawan pelaksana (buruh). Umumnya gaji dibayarkan secara tetap perbulan, sedangkan upah dibayarkan berdasarkan hari kerja, jam kerja atau jumlah satuan produk yang di hasilkan.

Dari pendapat di atas, dapat disimpulkan bahwa gaji merupakan balas jasa yang diberikan kepada karyawan yang mempunyai ikatan kerja kuat secara berkala berdasarkan ketentuan yang berlaku di perusahaan dan sifatnya tetap. Sedangkan upah merupakan balas jasa yang di berikan kepada karyawan yang ikatan kerjanya kurang kuat berdasarkan waktu kerja setiap hari ataupun setiap minggu. 


\section{Pengertian Sistem Akuntansi Gaji dan Upah}

Adanya sistem akuntansi yang memadai, menjadikan akuntan perusahaan dapat menyediakan informasi keuangan bagi setiap tingkatan manajemen, para pemilik atau pemegang saham, kreditur dan para pemakai laporan keuangan (stakeholder) lain yang dijadikan dasar pengambilan keputusan ekonomi. Sistem tersebut dapat digunakan oleh manajemen untuk merencanakan dan mengendalikan operasi perusahaan. Salah satu sistem yang dapat digunakan oleh manajemen perusahaan adalah sistem akuntansi gaji dan upah.

Untuk mengatasi adanya kesalahan dan penyimpangan dalam perhitungan dan pembayaran gaji dan upah maka perlu dibuat suatu sistem penggajian dan pengupahan. Sistem akuntansi gaji dan upah juga dirancang oleh perusahaan untuk memberikan gambaran yang jelas mengenai gaji dan upah karyawan sehingga mudah dipahami dan mudah digunakan.

Berikut ini akan dibahas pengertian sistem akuntansi gaji dan upah menurut beberapa ahli. Neunar (1997:210) mengemukakan bahwa: Sistem akuntansi gaji dan upah untuk kebanyakan perusahaan adalah suatu sistem dari prosedur dan catatan-catatan yang memberikan kemungkinan untuk menentukan dengan cepat dan tepat berapa jumlah pendapatan kotor setiap pegawai, berapa jumlah yang harus dikurangi dan pendapatan untuk berbagai pajak dan potongan lainnya dan berapa saldo yang harus diberikan kepada karyawan. 
Sedangkan Baridwan (1999:102) menyatakan sistem akuntansi gaji dan upah adalah "Suatu kerangka dari prosedur yang saling berhubungan sesuai dengan skema yang menyeluruh untuk melaksanakan kegiatan dan fungsi utama perusahaan".

Selanjutnya menurut Mulyadi (2001:17) menyatakan

Sistem akuntansi gaji dan upah dirancang untuk menangani transaksi perhitungan gaji dan upah karyawan dan pembayarannya, perancangan sistem akuntansi penggajian dan pengupahan ini harus dapat menjamin validitas, otorisasi kelengkapan, klasifikasi penilaian, ketepatan waktu dan ketepatan posting serta ikhtisar dari setiap transaksi penggajian dan pengupahan.

Dari pendapat diatas, dapat disimpulkan bahwa sistem akuntansi gaji dan upah merupakan rangkaian prosedur perhitungan dan pembayaran gaji dan upah secara menyeluruh bagi karyawan secara efisien dan efektif. Tentunya dengan sistem akuntansi gaji dan upah yang baik perusahaan akan mampu memotivasi semangat kerja karyawan yang kurang produktif dan mempertahankan karyawannya yang produktif, sehingga tujuan perusahaan untuk mencari laba tercapai dengan produktifitas kerja karyawan yang tinggi.

\section{Dokumen Yang Digunakan dalam Akuntansi Gaji dan Upah}

Dokumen atau formulir merupakan media untuk mencatat peristiwa yang taerjadi dalam organisasi ke dalam catatan. 
Dokumen sangat penting dalam akuntansi sebab untuk mencatat dan menghitung gaji dan upah menggunakan bukti-bukti yang terdapat pada dokumen.

Menurut Mulyadi (2001:374) dokumen yang digunakan dalam sistem akuntansi gaji dan upah adalah:

1. Dokumen pendukung perubahan gaji dan upah

2. Kartu jam hadir

3. Kartu jam kerja

4. Daftar gaji dan upah

5. Rekap daftar gaji dan upah

6. Surat pernyataan gaji dan upah

7. Amplop gaji dan upah

8. Bukti kas keluar

Dokumen pendukung perubahan gaji. Dokumen ini umumnya dikeluarkan oleh fungsi kepegawaian berupa surat keputusan yang berhubungan dengan karyawan, seperti misalnya: surat keputusan pengangkatan karyawan baru, kenaikan pangkat, skorsing dan sebagainya. Tembusan dokumen ini dikirimkan ke fungsi pembuat daftar gaji dan upah untuk kepentingan pembuatan daftar gaji dan upah. 
Kartu jam hadir. Kartu jam hadir ini digunakan oleh fungsi pencatat waktu untuk mencatat jam hadir setiap karyawan di perusahaan. Catatan jam hadir dapat berupa daftar hadir biasa dapat pula berbentuk kartu hadir yang diisi dari mesin pencatat waktu.

Kartu jam kerja. Kartu jam kerja merupakan dokumen yang digunakan untuk mencatat waktu yang dikonsumsi tenaga kerja langsung pada perusahaan yang diproduksinya berdasarkan pesanan.

Daftar gaji dan upah. Daftar gaji dan upah merupakan dokumen yang memuat informasi mengenai jumlah gaji bruto tiap karyawan, potongan-potongan serta jumlah gaji netto tiap karyawan dalam suatu periode pembayaran.

Rekap daftar gaji dan upah. Rekap daftar gaji dan upah merupakan dokumen yang berisi ringkasan gaji perdepartemen/bagian, yang dibuat berdasarkan daftar gaji.

Surat pernyataan gaji dan upah. Surat pernyataan gaji dan upah merupakan dokumen yang dibuat oleh fungsi pembuat daftar gaji, yang merupakan catatan bagi tiap karyawan beserta berbagai potongan yang menjadi beban bagi karyawan.

Amplop gaji dan upah. Amplop gaji dan upah ini berisi uang gaji karyawan yang memuat informsi mengenai nama karyawan, nomor identifikasi, dan jumlah gaji bersih yang diterima karyawan dalam bulan atau periode tertentu. 
Bukti kas keluar. Brdasarkan informasi dalam daftar gaji yang diterima dari fungsi pembuat daftar gaji, maka fungsi pencatat uang akan membuat dokumen yang merupakan perintah pengeluaran uang kepada fungsi pembayaran gaji.

\section{Catatan Akuntansi Yang Digunakan}

Akuntansi mempunyai fungsi dan peranan bersifat keuangan yang sangat penting dalam kegiatan perusahaan dan kepada pihak-pihak tertentu yang memerlukannya.

Mulyadi (2001: 382) menyatakan catatan akuntansi yang digunakan dalam pencatatan gaji dan upah meliputi:

1). Jurnal umum;

2). Kartu harga pokok produk;

3). Kartu biaya;

4). Kartu penghasilan karyawan.

Jurnal Umum. Dalam gaji dan upah, jurnal umum digunakan untuk mencatat distribusi biaya tenaga kerja ke dalam setiap departemen dalam perusahaan.

Kartu harga pokok produk. Kartu ini digunakan untuk mencatat upah tenaga kerja langsung yang dikeluarkan untuk pesanan tertentu. 
Kartu biaya. Catatan ini digunakan untuk mencatat biaya tenaga kerja tidak langsung dan biaya tenaga kerja non produksi setiap departemen dalam perusahaan. Sumber informasi untuk pencatatan dalam kartu biaya ini adalah bukti memorial.

Kartu penghasilan karyawan. Catatan ini digunakan untuk mencatat penghasilan dan berbagai potongan yang diterima oleh setiap karyawann. Kartu penghasilan karyawan digunakan sebagai tanda terima gaji dan upah karyawan dengan ditandatanganinya kartu tersebut oleh karyawan yang bersangkutan. Sehingga rahasia penghasilan keryawan tertentu tidak diketahui oleh karyawan yang lain.

\section{Fungsi Yang Terkait Dalam Gaji dan Upah}

Dalam sistem akuntansi gaji dan upah perusahaan terdapat beberapa fungsi yang terkait dalam pencatatan dan pemberian gaji dan upah karyawan. Fungsi tersebut saling bekerja sama dan saling berhubungan satu dengan yang lainnya untuk tujuan tertentu.

Menurut Mulyadi (2001:382) fungsi yang terkait dalam sistem akuntansi gaji dan upah adalah: 1). Fungsi kepegawaian; 2). Fungsi pencatatan waktu; 3). Fungsi pembuat daftar gaji dan upah; 4). Fungsi akuntansi; 5). Fungsi keuangan.

Fungsi kepegawaian. Fungsi ini bertanggung jawab untuk mencari karyawan baru, menyeleksi calon karyawan, memutuskan penempatan karyawan baru, membuat surat keputusan tarif gaji 
dan upah karyawan, kanaikan pangkat dan golongan gaji, mutasi karyawan dan pemberhentian karyawan.

Fungsi pencatat waktu. Fungsi ini bertanggung jawab untuk menyelenggarakan catatan waktu hadir bagi semua karyawan perusahaan. Fungsi pencatatan waktu hadir karyawan tidak boleh dilaksanakan oleh fungsi operasi atau oleh fungsi pembuat daftar gaji dan upah.

Fungsi pembuat daftar gaji dan upah bertanggung jawab untuk membuat daftar gaji dan upah yang berisi penghasilan bruto yang menjadi hak dan berbagai potongan yang menjadi beban setiap karyawan selama jangka waktu pembayaran gaji dan upah. Daftar gaji dan upah diserahkan oleh pembuat daftar gaji dan upah kepada fungsi akuntansi guna pembuatan bukti kas keluar yang dipakai sebagai dasar pembayaran gaji dan upah.

Fungsi akuntansi bertanggung jawab untuk mencatat kewajiban yang timbul dalam hubungannya dengan pembayaran gaji dan upah karyawan (misalnya utang gaji dan upah karyawan, utang pajak, utang dana pensiun). Fungsi akuntansi yang menangani sistem akuntansi penggajian dan pengupahan berada ditangan bagian utang, bagian kartu biaya, dan bagian jurnal.

Fungsi keuangan bertanggung jawab untuk mengisi cek guna pembayaran gaji dan upah dan menguangkan cek tersebut ke bank. Uang tunai tersebut kemudian dimasukkan ke dalam amplop gaji dan upah setiap karyawan untuk selanjutnya dibagikan kepada karyawan yang berhak. 
Fungsi-fungsi tersebut diatas, saling bekerja sama dan terkait satu dengan yang lainnya sehingga membentuk suatu sistem penggajian dan pengupahan yang baik.

Jaringan Prosedur Yang Membentuk Sistem Akuntansi Gaji dan Upah

Suatu sistem yang baik untuk suatu perusahaan belum tentu baik untuk perusahaan lain, meskipun perusahaan tersebut termasuk perusahaan yang sejenis usahanya.

Supaya sistem ini dapat berjalan harus meliputi prosedurprosedur yang dapat menemukan atau memberi isyarat tentang terjadinya keganjilan-keganjilan dalam sistem pertanggungjawaban atas transaksi atau kekayaan perusahaan yang dikuasakan kepadanya.

Prosedur merupakan rangkaian kegiatan yang saling berhubungan satu dengan yang lainnya, prosedur biasanya melibatkan beberapa orang dalam suatu departemen. Prosedur ini dibuat untuk menjamin penanganan secara seragam transaksi perusahaan yang terjadi berulang-ulang

Menurut Baridwan (1999:17) sistem akuntansi gaji dan upah terdiri dari tiga prosedur yaitu: 1). Prosedur untuk bagian personalia; 2). Prosedur pencatatan waktu; 3). Prosedur penggajian dan pengupahan. 
Prosedur personalia. Prosedur ini melibatkan berbagai personalia dan bagian lain yang membutuhkan karyawan baru. Fungsi organisasi yang terkait dengan prosedur personalia adalah:

1. Mencari karyawan baru, terdiri dari kegiatan-kegiatan:

a). Membuat catatan mengenai karyawan yang berhenti atau diberhentikan dan mencari penggantinya dari pelamar-pelamar baru.

b). Memelihara hubungan dengan kantor penempatan kerja, sekolah-sekolah, universitas dan sumbersumber karyawan lainnya.

c). Memasang advertensi.

2. Mengadakan interview.

3. Melakukan pekerjaan yang berhubungan dengan adanya karyawan baru, sebagai berikut:

a). Mencari data pribadi karyawan.

b). Menyelenggarakan tes kesehatan

c). Membuat formulir penerimaan yang digunakan untuk menempatkan nama pegawai dalam daftar gaji.

4. Melakukan berbagai yang terdapat dibawah ini: 
a). Membuat catatan mengenai potongan-potongan gaji yang diminta oleh pihak luar.

b). Membuat catatan mengenai lokasi karyawan.

c). Membuat catatan mengenai sebab-sebab berhentinya karyawan.

d). Membuat catatan sejarah karyawan

e). Membuat catatan untuk menentukan cuti karyawan

Sedangkan formulir yang digunakan dalam prosedur personalia ini adalah:

1). Surat permintaan karyawan baru, formulir ini dibuat oleh mandor atau bagian lain untuk meminta tambahan karyawan dan diserahkan kepada bagian personalia;

2). Surat lamaran kerja, surat ini bisa ditulis oleh calon karyawan atau mungkin sudah disediakan formulirnya dan calon karyawan tinggal mengisinya, data dalam surat lamaran biasanya terdiri dari umur, pendidikan, keahlian, pengalaman dan lain-lain;

3). Surat perjanjian kerja, formulir ini dibuat oleh bagian personalia untuk karyawan-karyawan yang diterima, satu lembar dari surat perjanjian kerja ini diserahkan kebagian gaji dan upah sabagai dasar untuk memasukkan nama pegawai dalam daftar gaji dan upah; 
4). Laporan pemberhentian, formulir ini dibuat oleh mandor sebagai pemberitahuan bahwa karyawan sudah berhenti bekerja dan diserahkan ke bagian personalia.

Prosedur pencatatan waktu. Dalam prosedur pencatatan waktu, pekerjaan mencatat waktu pada dasarnya dapat dipisahkan menjadi dua bagian yaitu pencatatan waktu hadir dan pencatatan waktu kerja. Adapun formulir yang digunakan dalam prosedur pencatatan waktu adalah:

1). Catatan waktu hadir (Clock Card), yaitu kartu yang dibuat untuk masing-masing karyawan, yang menunjukkan jam datang dan jam pulang. Kartu ini dimasukkan dalam attendance time recorder pada waktu kayawan datang maupun pulang, sehingga tercatat jam datang dan jam pulang. Daftar hadir yang ditandatangani karyawan setiap hari untuk setiap bagian dalam perusahaan disediakan kartu lembar daftar hadir atau mungkin lebih dari satu lembar. Karyawan diminta untuk menandatangani daftar itu setiap hari;

2). Catatan waktu kerja, catatan waktu kerja dapat dikumpulkan oleh petugasnya dari buku catatan mandor dan daftar hadir, job card atau job tiket;

3). Kombinasi catatan waktu hadir dan waktu kerja, catatan waktu hadir dan waktu kerja dapat dibuat dalam bentuk satu lembar untuk tiap karyawan setiap hari. Lembar tersebut menunjukkan waktu yang digunakan karyawan 
untuk mengerjakan job pada hari itu dan juga disediakan kolom untuk mencatat jam datang dan jam pulang.

Prosedur penggajian dan pengupahan. Prosedur ini menggunakan formulir dan laporan sebagai berikut:

1). Daftar gaji dan chek register, daftar gaji merupakan daftar yang menunjukkan perhitungan gaji dan upah masingmasing karyawan selama periode tertentu. Daftar gaji ini merupakan buku jurnal gaji. Dalam daftar gaji, setiap baris digunakan untuk satu karyawan, menunjukkan nama, nomor, kartu hadir jam kerja biasa dan lembur, tarif upah/gaji, jumlah gaji biasa dan lembur, tunjangantunjangan, potongan-potongan dan jumlah gaji bersih;

2). Cek gaji atau amplop gaji, cek gaji dibuat apabila pembayaran gaji menggunakan cek, tetapi bila gaji dibayar dengan uang tunai maka digunakan amplop gaji. Baik cek gaji maupun amplop gaji harus menunjukkan nama karyawan dan jumlah gaji bersihnya;

3). Paystub atau employee's earning statement (laporan gaji karyawan), merupakan formulir yang berisi data gaji kotor dan potongan-potongan, serta gaji bersih. Laporan ini diserahkan pada karyawan bersama gajji dan upahnya;

4). Empoyee's record (Catatan gaji karyawan), merupakan catatan yang menunjukkan kumpulan gaji dan upah karyawan selama periode tertentu. Catatan ini dibuat terinci seperti daftar gaji dan upah untuk setiap karyawan. 
Selanjutnya menurut Mulyadi (2001:385) sistem penggajian terdiri dari jaringan prosedur berikut:

1. Prosedur pencatatan waktu hadir.

2. Prosedur pembuatan daftar gaji

3. Prosedur distribusi biaya gaji

4. Prosedur pembuatan bukti kas keluar

5. Prosedur pembayaran gaji

Prosedur pencatatan waktu hadir. Prosedur ini bertujuan untuk mencatat waktu hadir karyawan. Pencatatan waktu hadir ini diselenggarakan oleh fungsi pencatat waktu dengan menggunakan daftar hadir pada pintu masuk kantor administrasi. Pencatatan waktu hadir dapat menggunakan daftar hadir biasa, yang karyawan harus menandatanganinya setiap hadir dan pulang dari perusahan atau dapat menggunakan kartu hadir (berupa clok card) yang diisi secara otomatis dengan menggunakan mesin pencatat waktu (time recorder mechine).

Prosedur pencatat waktu kerja. Dalam perusahaan manufaktur yang produksinya berdasarkan pesanan, pencatatan waktu kerja diperlukan bagi karyawan yang bekerja di fungsi produksi untuk keperluan distribusi biaya upah karyawan kepada produk atau pesanan yang menikmati jasa karyawan tersebut. Dengan demikian waktu kerja ini dipakai sebagai dasar 
pembebanan biaya tenaga kerja langsung kepada produk yang diproduksi.

Prosedur pembuatan daftar gaji dan upah. Dalam prosedur ini fungsi pembuat daftar gaji dan upah membuat daftar gaji dan upah karyawan. Data yang dipakai sebagai dasar pembuatan daftar gaji dan upah adalah surat-surat keputusan mengenai pengangkatan karyawan, daftar gaji bulan sebelumnya dan daftar hadir.

Prosedur distribusi biaya gaji dan upah. Dalam prosedur ini, biaya tenaga kerja didistribusikan kepada departemendepartemen yang menikmati manfaat tenaga kerja. Distribusi tenaga kerja ini dimaksudkan untuk pengendalian biaya dan perhitungan harga pokok produk.

Prosedur pembayaran gaji dan upah. Prosedur ini melibatkan fungsi akuntansi dam fungsi keuangan. Fungsi akuntansi membuat perintah pengeluran kas kepada fungsi keuangan untuk menulis cek guna pembayaran gaji dan upah. Fungsi keuangan kemudian menguangkan cek tersebut ke bank dan memasukkan uang ke dalam amplop gaji dan upah dilakukan oleh juru bayar (pay master).

\section{Unsur Pengendalian Intern}

Suatu sistem akuntansi yang baik belum tentu akan berhasil mencapai tujuan perusahaan apabila manajemen tidak dapat mengendalikannya. Untuk itu dalam menjalankan sistem akuntansi gaji dan upah diperlukan pengendalian intern. 
Pengendalian intern yang baik dan memadai harus terdiri dari beberapa unsur yang saling mendukung dan sama pentingnya dalam satuan usaha pengendalian intern. Jika terdapat kelemahan dalam suatu unsur dapat mengakibatkan terhambatnya tujuan dari pengendalian intern tersebut.

Pengendalian intern merupakan kunci terlaksananya sistem akuntansi gaji dan upah. Mulyadi (2001: 164) menyatakan "bahwa unsur pokok sistem pengendalian intern adalah:

1. Struktur organisasi yang memisahkan tanggungjawab fungsional secara tegas.

2. Sistem wewenang dan prosedur pencatatan yang memberikan perlindungan yang cukup terhadap kekayaan, utang, pendapatan dan biaya.

3. Praktek yang sehat dalam melaksanakan tugas dan fungsi setiap unit organisasi.

4. Karyawan yang mutunya sesuai dengan tanggung jawabnya.

Struktur organisasi yang memisahkan tanggungjawab fungsional secara tegas. Dalam sistem akuntansi gaji dan upah untuk pengendalian intern perlu memisahkan tanggungjawab fungsional secara tegas. Adapun fungsi yang harus dipisahkan adalah: 1). Fungsi pembuatan daftar gaji dan upah harus terpisah dari fungsi pembayaran gaji dan upah; 2). Fungsi pencatatan waktu hadir harus terpisah dari fungsi operasi. 
Sistem wewenang dan prosedur pencatatan yang memberikan perlindungan yang cukup terhadap kekayaan, utang, pendapatan dan biaya. Wewenang dan prosedur pencatatan yang dilakukan untuk memberikan perlindungan adalah:

1. Setiap orang yang namanya tercantum dalam daftar gaji dan upah harus memiliki surat keputusan pengangkatan sebagai karyawan perusahaan yang ditandatangani oleh direktur utama.

2. Setiap perubahan gaji dan upah karyawan karena perubahan pangkat, perubahan tarif gaji dan upah, tambahan keluarga harus didasarkan pada surat keputusan direktur keuangan.

3. Setiap potongan atas gaji dan upah karyawan selain dari pajak penghasilan karyawan harus didasarkan surat potongan gaji dan upah yang diotorisasi oleh fungsi kepegawaian.

4. Perintah lembur harus diotorisasi oleh kepala departemen karyawan yang bersangkutan.

5. Daftar gaji dan upah harus diotorisasi oleh fungsi personalia.

6. Bukti kas keluar untuk pembayaran gaji dan upah harus diotorisasi oleh fungsi akuntansi.

7. Perubahan dalam catatan penghasilan karyawan direkonsiliasi dengan daftar gaji dan upah karyawan. 
8. Tarif upah yang dicantumkan dalam kartu jam kerja diverifikasi ketelitiannya oleh fungsi akuntansi biaya.

Praktek yang sehat dalam melaksanakan tugas dan fungsi setiap unit organisasi. Adapun praktek sehat yang dilakukan dalam sistem akuntansi gaji dan upah adalah:

1. Kartu jam hadir harus dibandingkan dengan kartu jam kerja sebelum kartu yang terakhir ini dipakai sebagai dasar distribusi biaya tenaga kerja langsung.

2. Pemasukan kartu jam hadir ke dalam mesin pencatat waktu harus diawasi oleh fungsi pencatat waktu.

3. Pembuatan daftar gaji dan upah harus diverifikasi kebenaran dan ketelitian perhitungannya oleh fungsi akuntansi keuangan sebelum dilakukan pembayaran.

4. Penghitunagn pajak penghasilan karyawan direkonsiliasi dengan catatan penghasilan karyawan.

5. Catatan penghasilan karyawan disimpan oleh fungsi pembuat daftar gaji dan upah.

Karyawan yang mutunya sesuai dengan tanggung jawabnya. Ketiga unsur di atas dapat menciptakan dan mendorong praktek yang sehat jika perusahaan memiliki karyawan yang kompeten dan jujur. Karyawan yang jujur dan ahli dalam bidangnya akan mampu melaksanakan pekerjaannya dengan efisien dan efektif. 
6.2. Flowchart siklus penggajian

\section{BAGAN ALIR PENGGAJIAN (AKTIVITAS MINGGUAN/BULANAN)}
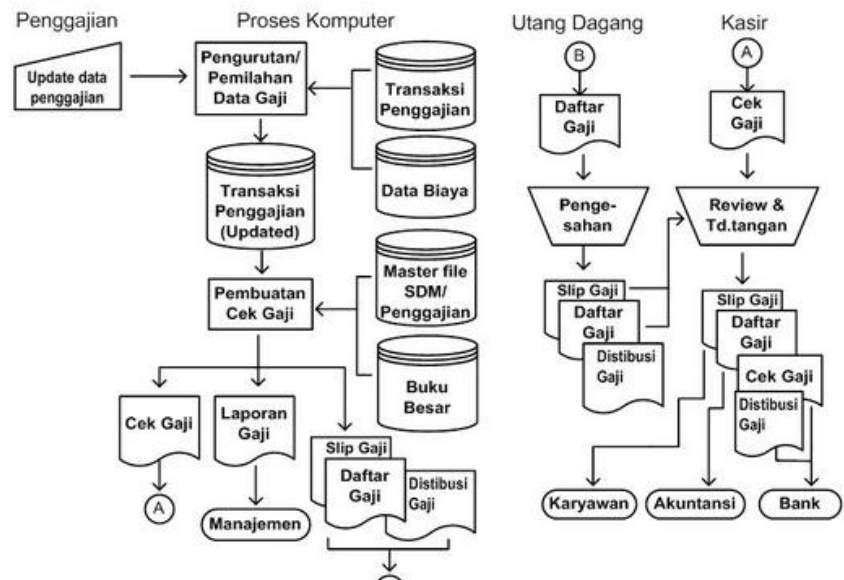

(B)

\section{PROSEDUR PENGGAJIAN BERBANTUAN KOMPUTER (ALTERNATIF)}

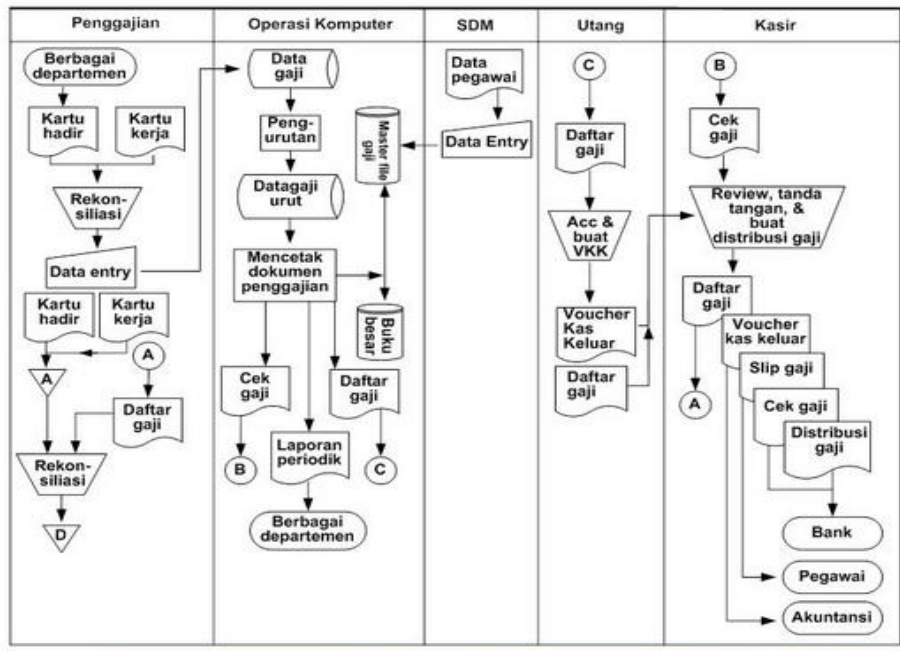




\subsection{Opsi outsourcing: biro jasa penggajian dan organisasi pengusaha professional}

Outsourcing menurut definisi Maurice Greaver, Outsourcing (Alih Daya) dipandang sebagai tindakan mengalihkan beberapa aktivitas perusahaan dan hak pengambilan keputusannya kepada pihak lain (outside provider), dimana tindakan ini terikat dalam suatu kontrak kerjasama. Secara umum outsourcing merupakan proses pemindahan tanggung jawab tenaga kerja dari perusahaan induk ke perusahaan lain diluar perusahaan induk. Perusahaan diluar perusahaan induk bisa berupa vendor, koperasi ataupun instansi lain yang diatur dalam suatu kesepakatan tertentu.

Pada era persaingan global dan kompetisi yang semakin ketat, setiap perusahaan harus mampu melakukan inovasi untuk bertahan, salah satunya adalah dengan menerapkan teknologi tepat guna. Sistem informasi merupakan salah satu alat (tool) yang sering digunakan oleh perusahaan untuk mewujudkan tujuan perusahan demi mencapai efektifitas dan efesiensi perusahaan. Organisasi (perusahaan) dan sistem informasi memerlukan kontribusi, komitmen dan kepedulian untuk mendapatkan potensi yang sesungguhnya. Efektifitas dan efisiensi dalam mentransfer teknologi memerlukan perubahan yang terus menerus dan berkelanjutan. Teknologi dan sistem informasi yang merupakan kolaborasi antara teknologi informasi dan komunikasi yang memainkan peran utama pengembangan sistem informasi 
Disadari dalam mengembangkan sistem informasi tidak sedikit biaya yang harus dikeluarkan. Perusahaan pun senantiasa melakukan efisiensi biaya dalam berbagai komponen pengeluaran keuangan perusahaan untuk dapat memenangkan persaingan. Salah satu cara yang dilakukan perusahaan dalam mengembangkan sistem informasi dan sekaligus dalam rangka melakukan efisiensi biaya yaitu dengan sistem outsourcing Selain efisiensi biaya adanya sistem outsourcing ini juga didasari karena adanya keterbatasan yang dimiliki perusahaan baik dalam bidang pengetahuan Sumber daya manusia (SDM) yang dimiliki, keterbatasan informasi, keterbatasan peralatan dan keterbatasan-keterbatasan lainnya. Namun demikian Outsourcing harus dipandang secara jangka panjang, karena perusahaan pasti akan mengeluarkan dana dan sumber daya yang lebih sebagai management fee perusahaan outsourcing, memikirkan mengenai pengembangan karir karyawan, efisiensi dalam bidang tenaga kerja, organisasi, benefit dan lainnya. Oleh karena itu pemilihan sistem outsourcing harus dianalisis dan dilakukan dengan baik sehingga sehingga memberikan manfaat yang besar serta mampu meningkatkan dan berkontribusi besar terhadap kinerja perusahaan secara tepat dan efisien.

Pada buku ajar ini akan mencoba membahas tentang alasanalasan mengapa perusahaan melakukan outsourcing, bagaimana keuntungan dan kelemahan pengembangan sistem informasi secara outsourcing dibandingkan insourcing serta hal-hal apa yang harus diperhatikan dalam penerapan outsourcing. 


\section{DEFINISI OUTSOURCING DAN INSOURCING}

Outsourcing merupakan penyerahan tugas atau pekerjaan yang berhubungan dengan operasional perusahaan ataupun pengerjaan proyek kepada pihak ketiga atau perusahaan ketiga dengan menetapkan jangka waktu tertentu dan biaya tertentu dalam proses pengembangan proyeknya. Outsourcing $\mathrm{TI}$ atau pengadaan sarana dan jasa TI oleh pihak ketiga merupakan kebijakan strategis perusahaan yang berpengaruh terhadap proses bisnis dan bentuk dukungan TI yang akan diperoleh.

Melalui outsourcing, perusahaan dapat membeli sistem informasi yang sudah tersedia, atau sudah dikembangkan oleh perusahaan outsourc. Perusahaan juga dapat meminta perusahaan outsource untuk memodifikasi sistem yang sudah ada. Perusahaan juga dapat membeli software dan meminta perusahaan outsource untuk memodifikasi software tersebut sesuai keinginan perusahaan. Dan juga lewat outsourcing perusahaan dapat meminta untuk mengembangkan sistem informasi yang benarbenar baru atau pengembangan dari dasar.

Salah satu pendekatan yang dapat dilakukan dalam pengembangan sistem informasi yaitu pendekatan insourcing. Jika outsourcing melimpahkan pengerjaan proyek pada pihak ketiga, insourcing mengembangan proyek dengan memanfaatkan spesialis IT dalam perusahaan tersebut. Insourcing merupakan metode pengembangan sistem informasi yang hanya melibatkan sumber daya di dalam suatu organisasi atau suatu perusahaan.

\section{ALASAN PERUSAHAAN MELAKUKAN OUTSOURCING}


Melakukan outsourcing, baik seluruh operasional ataupun bagianbagian tertentu mempunyai prospek untuk menurunkan biaya dengan implementasi operasional yang lebih baik, karena dilakukan oleh pihak ketiga yang fokus bisnisnya memberikan pelayanan TI. Menurut Volker Mahnke, Mikkel Lucas Overby \& Jan Vang (2003) dalam makalahnya di DRUID Summer Conference 2003 menyatakan bahwa tiga pokok utama outsourcing TI untuk memperbaiki Sistem Informasi yaitu meningkatkan kinerja bisnis, menghasilkan pendapatan baru dan yang dapat membantu perusahaan untuk menilai outsourcing. Menurut Taylor (2005) menyatakan bahwa outsourcing pada proyek multinasional IT menjadi lebih umum dalam mengelola resiko proyek untuk menghindari gagalnya proyek dengan mencatat resiko yang spesifik dan membedakan dari pesaing maupun vendor outsourcing yang tidak kompenten. Benefit yang didapat dari outsourcing dapat berupa tangible (seperti keseimbangan biaya outsourcing yang dikeluarkan) dan intangible (tingkat pelayanan yang diberikan secara professional). Tak heran bila kebutuhan terhadap jasa outsource ini semakin meningkat dari tahun ke tahun.

Alasan terkuat yang mendorong organisasi untuk menggunakan outsourcing yaitu tingkat persaingan bisnis yang semakin meningkat. Tingkat persaingan bisnis meningkat dengan meningkatnya kebutuhan teknologi informasi yang dapat meningkatkan nilai bisnis, ini dapat dicerminkan dalam karakteristik strategik secara umum memiliki beberapa faktor yaitu : cost leadership, differentiation, dan focus. 
Menurut O'Brien dan Marakas (2006), beberapa pertimbangan perusahaan untuk memilih strategi outsourcing sebagai alternatif dalam mengembangkan Sistem Informasi Sumberdaya Informasi diantaranya:

1. Biaya pengembangan sistem sangat tinggi.

2. Resiko tidak kembalinya investasi yang dilkukan sangat tinggi.

3. Ketidakpastian untuk mendapatkan sistem yang tepat sesuai dengan spesifikasi yang diinginkan.

4. Faktor waktu/kecepatan.

5. Proses pembelajaran pelaksana sistem informasi membutuhkan jangka waktu yang cukup lama.

6. Tidak adanya jaminan loyalitas pekerja setelah bekerja cukup lama dan terampil

\section{KEUNTUNGAN DAN KELEMAHAN OUT-SOURCING}

\section{Keuntungan dan Kelemahan outsourcing}

Ada beberapa keunggulan atau keuntungan menggunakan outsourcing, dan juga kelemahan menggunakan outsourcing. Keunggulan atau keuntungan menggunakan outsourcing antara lain (Jogiyanto, 2003).

1. Biaya teknologi yang semakin meningkat dan akan lebih murah jika perusahaan tidak berinvestasi lagi tetapi menyerahkannya kepada pihak ketiga dalam bentuk outsourcing yang lebih murah dikarenakan outsourcer 
menerima jasa dari perusahaan lainnya sehingga biaya tetap outsourcer dapat dibagi beberapa perusahaan.

2. Mengurangi waktu proses, karena beberapa outsourcer dapat dipilih untuk bekerja bersama-sama menyediakan jasa ini kepada perusahaan.

3. Jasa yang diberikan oleh outsourcer lebih berkualitas dibandingkan dikerjakan sendiri secara internal, karena outsourcer memang spesialisasi dan ahli dibidang tersebut.

4. Perusahaan tidak mempunyai pengetahuan tentang sistem teknologi ini dan pihak outsourcer mempunyainya.

5. Perusahaan merasa tidak perlu dan tidak ingin melakukan transfer teknologi dan transfer pengetahuan yang dimiliki outsourcer.

6. Meningkatkan fleksibilitas untuk melakukan atau tidak melakukan investasi.

7. Mengurangi resiko kegagalan investasi yang mahal.

8. Penggunaan sumber daya sistem informasi belum optimal. Jika ini terjadi, perusahaan hanya menggunakan sumber daya sistem yang optimal pada saat-saat tertentu saja, sehingga sumber daya sistem informasi menjadi tidak dimanfaatkan pada waktu yang lainnya.

9. Perusahaan dapat menfokuskan pada pekerjaan lain yang lebih penting.

Disamping kelebihan-kelebihan yang diberikan oleh outsourcing, beberapa kelemahan juga perlu diperhatikan diantaranya: 
1. Jika aplikasi yang di outsource adalah aplikasi yang strategic maka dapat ditiru oleh pesaingnya yang juga dapat menjadi klien dari outsourcer yang sama.

2. Perusahaan akan kehilangan kendali terhadap aplikasi yang di outsource-kan. Jika aplikasinya adalah aplikasi kritikal yang harus ditangani jika terjadi gangguan, perusahaan akan menanggung resiko keterlambatan penanganan jika aplikasi ini di outsource-kan karena kendali ada di outsourcer yang harus dihubungi terlebih dahulu.

3. Jika kekuatan menawar ada outsourcer, perusahaan akan kehilangan banyak kendali di dalam memutuskan sesuatu apalagi jika terjadi konflik diantaranya

4. Perusahaan akan kehilangan keahlian dari belajar membangun dan mengopersikan aplikasi tersebut.

5. Pelanggaran kontrak, yang banyak terjadi ketika vendor menjanjikan banyak hal yang kelihatan wah sebelum kontrak ditanda tangani, namun tidak dapat direalisasikan ketika kontrak sudah berjalan.

6. Kontrak jangka panjang, dimana vendor menawarkan kontrak dalam jangka waktu yang relative panjang, dengan biaya yang mahal dan penalti pemutusan kontrak yang menyebabkan perusahaan tidak memiliki pilihan selain menjalankan kontrak sampai selesai 


\section{BAGIAN 7}

\section{SISTEM AKUNTANSI BIAYA}

\section{TUJUAN INSTRUKSIONAL UMUM}

Mampu memahami dan Mengaplikasikan (membuat) Siklus Produksi

\subsection{Sistem Akuntansi Biaya dan Produksi}

Sistem akuntansi biaya dalam perusahaan manufaktur erat hubungannya dengan sistem pengawasan produksi, karena sebagian besar kegiatan perusahaan manufaktur berada di dalam fungsi produksi. Oleh karena itu, dalam bab ini diuraikan dua sistem pengawasan produksi dan sistem akuntansi biaya.

Sistem Pengawasan Produksi

Sistem pengawasan produksi ditujukan untuk mengawasi pelaksanaan orderproduksi yang dikeluarkan oleh fungsi produksi.Dalam perusahaan yang produksinya berdasarkan pesanan pembeli, order yang diterima oleh fungsi penjualan dari pembeli.

Dokumen yang di gunakan dalam sistem pengawasan produksi adalah:

1.Surat order produksi

2.Daftar kebutuhan bahan

3.Daftar kegiatan produksi 

4.Bukti permintaan dan pengeluaran barang gudang
5.Bukti pengembalian barang gudang
6.Kartu jam kerja
7.Laporan produk selesai

Sistem pengawasan produksi ditujukan untuk mengawasi pelaksanaan order produksi yang dikeluarkan oleh fungsi produksi. Dalam perusahaan yang produksinya berdasarkan pesanan dari pembeli, order produksi erat hubungannya dengan order yang diterima oleh fungsi penjualan dari pembeli. Sistem akuntansi biaya adalah jaringan prosedur yang digunakan untuk mengumpulkan dan menyajikan laporan biaya.

Faktor yang mempengaruhi perancangan sistem akuntansi biaya adalah :

1. metode costing yang digunakan : full costing atau variable costing.

2. sistem akuntansi biaya standar atau sistem akuntansi biaya historis

3. proses produksi : produksi berdasarkan pesanan atau produksi berdasar proses informasi yang diperlukan manajemen dari sistem akuntansi biaya.

4. order produksi yang belum selesai

5. order produksi yang telah selesai 
6. harga pokok produk jadi

7. harga pokok produk yang masih dalam proses pada saat tertentu

8. biaya menurut pusat biaya

\section{Dokumen yang digunakan}

1. surat order produksi, merupakan surat perintah yang dikeluarkan oleh departemen produksi yang ditujukan kepada bagian-bagian yang terkait dengan proses pengolahan produk untuk memproduksi sejumlah produk dengan spesifikasi, cara produksi, fasilitas produksi, dan jangka waktu seperti yang tercantum dalam surat order produksi tersebut.

2. daftar kebutuhan bahan, merupakan daftar jenis dan kuantitas bahan baku yang diperlukan untuk memproses produksi seperti yang tercantum dalam surat order produksi.

3. daftar kegiatan produksi, merupakan daftar urutan jenis kegiatan dan fasilitas mesin yang diperlukan untuk memproduksi produk seperti yang tercantum dalam surat order produksi.

4. bukti permintaan dan pengeluaran barang gudang, merupakan formulir yang digunakan oleh fungsi produksi untuk meminta bahan baku dan bahan penolong, dan berfungsi sebagai bukti pengeluaran barang dari gudang. 
5. bukti pengembalian barang gudang, merupakan formulir yang digunakan oleh fungsi produksi untuk mengembalikan bahan baku dan bahan penolong ke fungsi gudang.

6. kartu jam kerja, merupakan kartu untuk mencatat jam kerja tenaga kerja langsung yang dikonsumsi untuk memproduksi produk yang tercantum dalam surat order produksi.

7. laporan produk selesai, dibuat oleh fungsi produksiuntuk memberitahukan selesainya pesanan produk tertentu kepada fungsi perencanaan dan pengawasan produksi, fungsi gudang, fungsi penjualan, fungsi akuntansi persediaan, dan fungsi akuntansi biaya.

8. bukti memorial (journal voucher), digunakan sebagai dasar pencatatan depresiasi aktiva tetap berwujud, amortisasi sewa dan aktiva tidak berwujud, dan pembebanan biaya overhead pabrik kepada produk berdasarkan tarif yang ditentukan dimuka.

9. bukti kas keluar, digunakan untuk mencatat biaya-biaya yang dibayar lewat kas.

\section{Catatan akuntansi yang digunakan}

1. jurnal pemakaian bahan baku, merupakan jurnal khusus yang digunakan untuk mencatat harga pokok bahan baku yang digunakan dalam produksi. 
2. jurnal umum, digunakan untuk mencatat transaksi pembayaran gaji dan upah, depresiasi aktiva tetap, amortisasi aktiva tidak berwujud, dan terpakainya persekot biaya.

3. register bukti kas keluar, digunakan untuk mencatat biaya overhead pabrik, biaya administrasi dan umum, biaya pemasaran yang berupa pengeluaran kas.

4. kartu harga pokok produk, catatan ini merupakan buku pembantu yang merinci biaya produksi yang dikeluarkan untuk pesanan tertentu.

5. kartu biaya, catatan ini merupakan buku pembantu yang merinci biaya overhead pabrik, biaya administrasi dan umum, dan biaya pemasaran.

\section{Fungsi yang terkait}

a. Fungsi penjualan, bertanggung jawab atas penerimaan order dari pelanggan dan meneruskan order tersebut ke fungsi produksi.

b. Fungsi produksi, bertanggung jawab atas pembuatan perintah produksi bagi fungsi-fungsi yang ada dibawahnya yang akan terkait dalam pelaksanaan produksi guna memenuhi permintaan produksi dari fungsi penjualan.

c. Fungsi perencanaan dan pengawasan produksi, merupakan fungsi staf yang membantu fungsi produksi dalam merencanakan dan mengawasi kegiatan produksi. 
Perencanaan produksi diwujudkan dalam perhitungan rencana kebutuhan bahan dan peralatan yang akan digunakan untuk memproduksi pesanan yang diterima dari fungsi penjualan.

d. Fungsi gudang, bertanggung jawab atas pelayanan permintaan bahan baku, bahan penolong dan barangyang lain yang digudangkan ; menerima produk jadi yang diserahkan oleh fungsi produksi.

e. Fungsi akuntansi biaya, bertanggung jawab atas pencatatan mutasi setiap jenis persediaan dan atas pencatatan biaya produksi langsung, biaya produksi tidak langsung, dan biaya nonproduksi ke dalam kartu biaya ; mencatat transaksi terjadinya biaya bahan baku, biaya tenaga kerja, biaya overhead pabrik, dan biaya non produksi ke dalam jurnal pemakaian bahan baku dan jurnal umum serta posting ringkasan jurnal tersebut ke rekening yang bersangkutan dalam buku besar.

\subsection{Formulir yang dibutuhkan dan Flowchart}

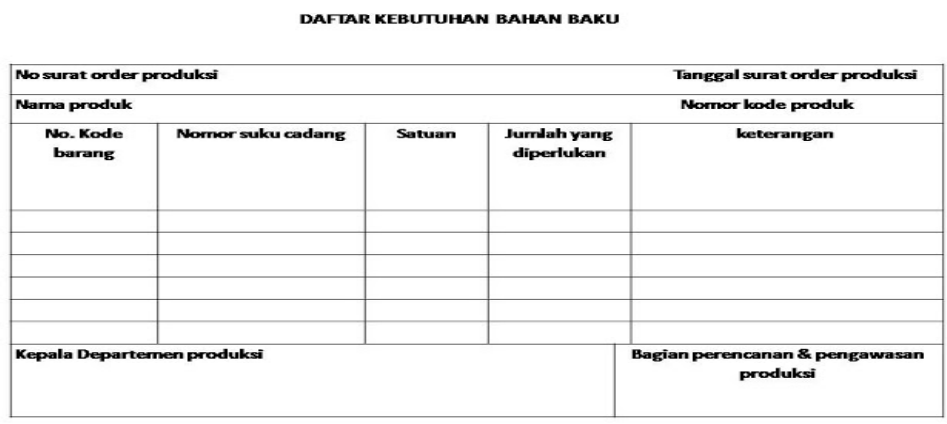


Laporan Inventory Harian Barang

Tanggal :

\begin{tabular}{|c|c|c|c|c|c|c|}
\hline No & Kode Material & Jenis Material & Stock Awal & Incoming & Issued Produksi & Stack Akhir \\
\hline \multicolumn{7}{|l|}{1} \\
\hline \multicolumn{7}{|l|}{2} \\
\hline \multicolumn{7}{|l|}{3} \\
\hline \multicolumn{7}{|l|}{4} \\
\hline \multicolumn{7}{|l|}{5} \\
\hline \multicolumn{7}{|l|}{6} \\
\hline \multicolumn{7}{|l|}{7} \\
\hline \multicolumn{7}{|l|}{ B } \\
\hline \multicolumn{7}{|l|}{9} \\
\hline \multicolumn{7}{|l|}{10} \\
\hline \multicolumn{7}{|l|}{11} \\
\hline \multicolumn{7}{|l|}{12} \\
\hline 13 & & & & & & \\
\hline & & & & & & \\
\hline
\end{tabular}

Dilaporkan Oleh.

Diketahui Oleh

Prosedur Pencatatan Harga Pokok Produk Jadi yang Dijual

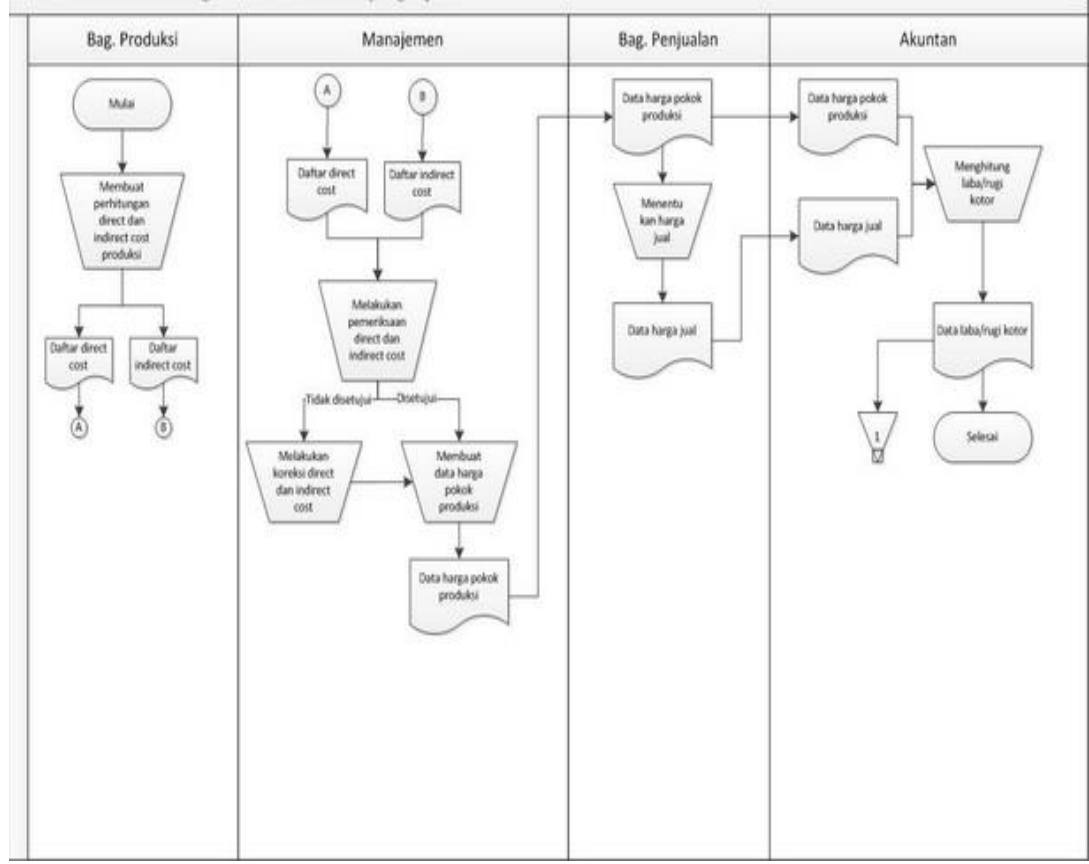




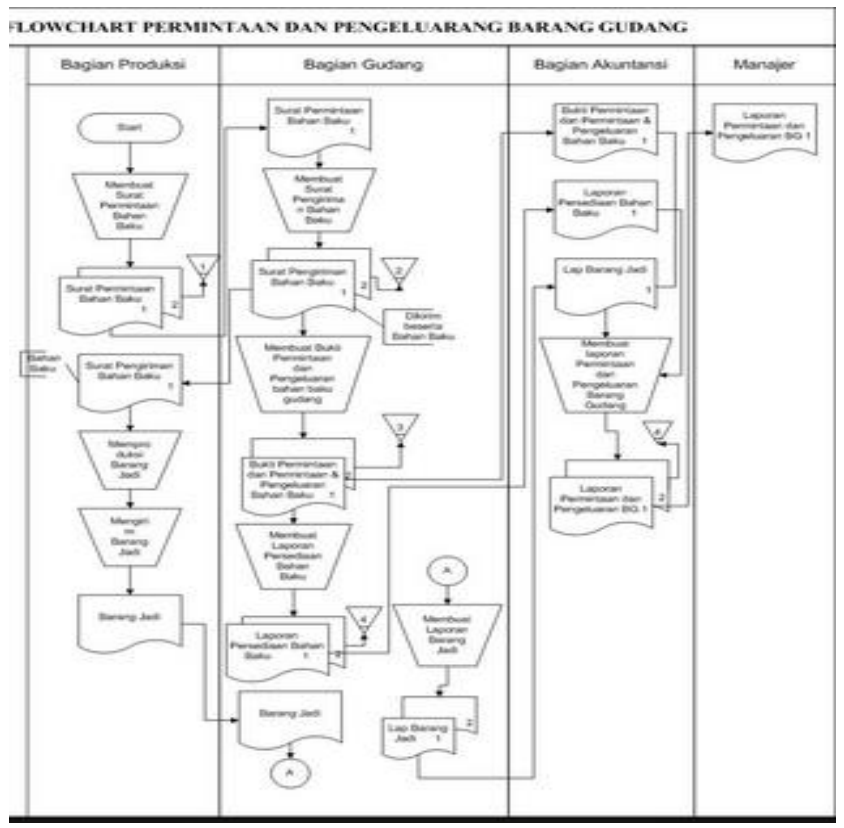




\section{TUJUAN INSTRUKSIONAL UMUM :}

Mampu memahami dan Mengaplikasikan (membuat) Strategi pengembangan SIA

\section{SUB BAGIAN :}

\section{Perkembangan Terkini Teknologi Informasi Akuntansi}

Perkembangan teknologi informasi akuntansi sebenarnya telah lama berlangsung. Alasan utama penggunaan akuntansi berbasis teknologi ialah efisiensi, penghematan waktu dan biaya. Selain itu, alasan peningkatan efektifitas untuk mendapatkan output laporan keuangan dengan benar dan tepat menjadi pemicu semakin berkembangnya penggunaan teknologi informasi di bidang akuntansi. Dalam piramida organisasi dan perusahaan, tugas dan fungsi akuntansi berada pada tingkatan operasional dan transaksional. Tingkatan ini punya karakteristik pekerjaan teknis, repetitif, prosedural, standar dan juga dapat membuat bosan. karakteristik inilah yang membuat kebutuhan teknologi informasi diperlukan dalam perkembangan bidang akuntansi. 


\section{Gambar Piramida Manajemen}

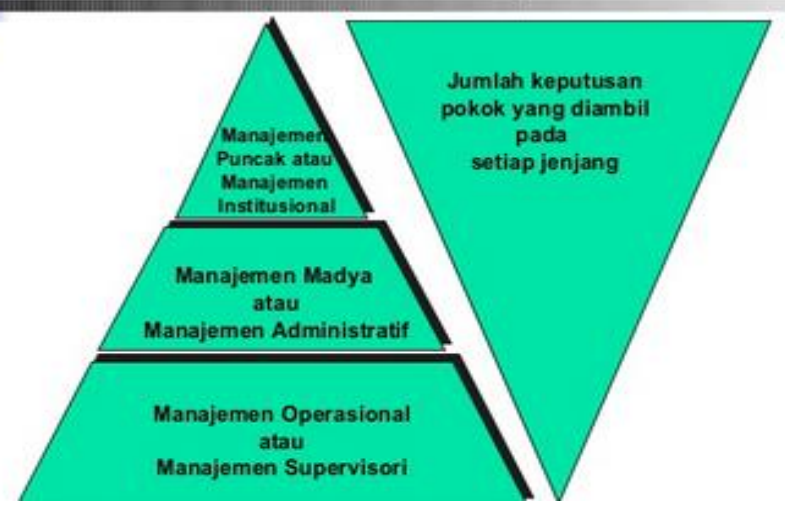

Dalam era bisnis global, pengaruh kemajuan teknologi informasi tidak dapat dihindarkan lagi, seperti penggunaan telepon, faksimili, komputer, dan satelit dalam berbagai aktivitas sarana berkomunikasi perusahaan. Teknologi informasi memungkinkan manusia untuk memperoleh informasi dari tempat yang berjauhan dalam waktu yang singkat dan dengan biaya yang murah. Manajemen organisasi harus tanggap pada perubahan lingkungan ini jika ingin organisasinya tetap dapat bertahan dan meningkat kinerjanya. Manajemen organisasi juga harus sensitif terhadap pengaruh perkembangan teknologi yang mencakup informasi, peralatan teknik dan proses dalam mengubah input menjadi output. Selain itu, manajemen harus dapat memahami dengan baik peran sistem informasi dalam organisasi (Eliot, 1992).

Pada Era desruption 4.0 saat ini informasi identik dengan cepat, instan dan mudah. Perkembangan pesat juga terjadi hampir disemua bidang seperti ilmu pengetahuan, teknologi dan bisnis. Perkembangan dibidang bisnis yang sangat kompetitif menuntut 
para pelaku bisnis untuk selalu berinovasi demi mempertahankan eksistensinya. Penyediaan informasi yang cepat dan tepat waktu menjadi salah satu hal yang wajib dimiliki oleh setiap pelaku bisnis untuk pengambilan keputusan supaya bisnis yang mereka jalani terus bisa bertahan atau bahkan menguasai pasar. Untuk mencapai penyediaan informasi perusahaan pelaku bisnis harus memahami apa itu sistem informasi akuntansi demi tersedianya informasi perusahaan tidak hanya cepat dan tepat waktu tetapi juga berkualitas. Dengan semakin berkembangnya teknologi informasi tersebut, hampir semua aktivitas organisasi saat ini telah dimasuki oleh aplikasi dan otomatisasi teknologi informasi.

Teknologi informasi dapat didefinisikan sebagai perpaduan antara teknologi komputer dan telekomunikasi dengan teknologi lainnya seperti perangkat keras, perangkat lunak, database, teknologi jaringan, dan peralatan telekomunikasi lainnya. Selanjutnya, teknologi informasi dipakai dalam sistem informasi organisasi untuk menyediakan informasi bagi para pemakai dalam rangka pengambilan keputusan. Ada berbagai macam sistem informasi dengan menggunakan teknologi informasi yang muncul, antara lain Electronic Data Processing Systems, Data Processing Systems (DPS), Decision Support System (DSS), Management Information System (MIS), Executive Information Systems (EIS), Expert System (ES) dan Accounting Information System (AIS) (Bodnar, 1998). Saluran komunikasi yang dapat digunakan untuk berkomunikasi adalah standard telephone lines, coaxial cable, fiber optics, microwave systems, communications satellites, cellular radio and telephone. Sedangkan konfigurasi jaringan yang dapat dipakai untuk berkomunikasi adalah Wide Area Network 
(WAN), Local Area Network (LAN), dan Client/Server Configurations (Romney, 2000)

Sistem Informasi Akuntansi (SIA) adalah sebuah sistem yang mengumpulkan, mencatat, menyimpan, memproses data atau transaksi perusahaan sehingga menjadi informasi berupa laporan keuangan yang bermanfaat untuk pengambilan keputusan (Gelinas Dull). Sistem ini bisa berupa manual mengunakan kertas, otomatis secara komputerisasi maupun kombinasi antara keduanya. Hanya saja sistem informasi akuntansi hanya memproses data-data keuangan sehingga informasi yang disajikan oleh sistem informasi akuntansi adalah informasi yang melibatkan unsur moneter saja berupa laporan keuangan.

SIA mengumpulkan data-data berupa transaksi-transaksi yang terjadi di perusahaan seperti transaksi pembelian, transaksi penjualan, transaksi pengeluaran kas maupun transaksi penerimaan kas. Transaksi-transaksi tersebut dapat dikategorikan sebagai data mentah yang belum diproses. SIA juga akan memproses data berupa transaksi-transaksi yang nantinya akan menghasilkan informasi laporan keuangan.

Laporan keuangan yang dihasilkan SIA juga harus mempunyai kriteria yang berkualitas dimana laporan keuangan tersebut benarbenar menggambarkan dan menyajikan kondisi perusahaan sehingga saat digunakan sebagai dasar pengambilan keputusan akan menghasilkan keputusan-keputusan yang tepat sasaran. Kriteria berkualitas dari laporan keuangan yaitu laporan keuangan mudah dipahami, tepat waktu, mempunyai nilai prediksi, dapat bibandingkan, bersifat obyektif, tepat dan lengkap. 
Perkembangan teknologi sekarang ini sangat membantu dalam perkembangan SIA itu sendiri sehingga SIA bisa menjadi alat bantu dalam pengambilan keputusan dalam upaya meningkatkan kinerja keuangan perusahaan. Peranan teknologi dalam SIA adalah lebih efisien, hemat waktu dan biaya dan efektifitas dalam penyediaan laporan keuangan yang benar. Walaupun SIA akan sangat membantu dalam penyediaan laporan keuangan, dalam prosesnya perlu adanya kontrol dari pelaku bisnis yang benarbenar paham mengenai alur bisnisnya sehingga terbentuklah laporan keuangan yang berkualitas.

Sistem informasi yang kini telah berkembang seiring dengan perkembangan teknologi yang begitu cepat ini telah terbukti sangat berperan penting dalam berbagai kegiatan perekonomial serta strategi penyelenggaraan pembangunan dalam berbagai bidang.Keberadaan sistem informasi sekarang telah mampu mendukung kinerja, peningkatan efisiensi, efektivitas dan juga produktivitas organisasi pemerintahan atau suatu bentuk usaha.

Dengan menerapkan sebuah sistem informasi dalam sebuah organisasi dapat membantu dalam berbagai aspek seperti meningkatkan efisiensi dan efektivitas proses bisnis mereka, pengambilan keputusan manajerial, kerja sama kelompok kerja hingga dapat memperkuat posisi kompetitif dalam pasar yang selalu berubah. Namun itu semua hanya dapat berlaku jika teknologi informasi tersebut telah di terapkan dalam organisasi.

\subsection{Penerapan Tekhnologi Informasi dalam Organisasi}


Berikut merupakan 5 hal dasar yang perlu di ketahui seputar sistem informasi atau biasa disebut 5 area pengetahuan sistem informasi

\section{Konsep - konsep dasar}

Konsep dasar ini meliputi keprilakuan, teknis, bisnis dan manajerial yang termasuk kedalam berbagai komponen dan peran sistem informasi. Contohnya seperti sebuah konsep sistem informasi yang berawal dari sebuah teori umum yang digunakan untuk mengembangkan sebuah aplikasi bisnis dengan tujuan keunggulan kompetitif.

\section{Teknologi informasi}

Konsep - konsep utama, pengembangan dan berbagai isu manajemen teknologi informasi yaitu meliputi hardware, software, jaringan, manajemen data, dan teknologi berbasis internet.

\section{Aplikasi bisnis}

Penggunaan utama dari sebuah sistem informasi yang berguna untuk operasional. Manajemen dan juga kompetitif bisnis.

\section{Proses pengembangan}

Sebuah proses dimana para pakar dan praktisi bisnis melakukan perencanaan, pengembangan dan 
pengimplementasian sistem informasi untuk memenuhi kebutuhan bisnis.

\section{Tantangan manajemen}

Tantangan yang dibuat secara efektif dan etis dalam mengelola teknologi informasi yang tersedia sehingga dapat digunakan pada pemakai akhir, perusahaan dan global dalam bisnis.

Peran utama Sistem Informasi dalam bisnis diantaranya

\section{Mendukung Operasi Bisnis}

Sistem informasi yang ada dapat menyediakan dukungan bagi manajemen dalam operasi atau kegiatan bisnis mulai dari akuntansi hingga penelusuran pesanan pelanggan.

\section{Mendukung Pengambilan Keputusan Bisnis}

Sistem informasi dapat memberikan laporan secara akurat yang dapat dikombinasikan untuk membantu menjalankan bisnis dengan lebih baik.

\section{Mendukung keunggulan bisnis}

Sistem informasi dirancang untuk dapat membantu pencapaian sasaran strategis perusahaan dalam menciptakan keunggulan bersaing di pasar. 


\subsection{Pengaruh Perkembangan Teknologi Informasi Akuntansi}

Perkembangan teknologi informasi akuntansi pada saat ini berpengaruh besar terhadap sistem informasi akuntansi (SIA) dalam suatu perusahaan. Dampak yang dapat dirasakan adalah pemrosesan data yang mengalami perubahan dari sistem manual ke sistem komputer. Oleh karena itu, pengendalian intern dalam SIA juga akan mempengaruhi peningkatan jumlah dan kualitas informasi dalam pelaporan keuangan. Perkembangan akuntansi dalam hal SIA berbasis komputer akan menghasilkan laporan keuangan yang mempengaruhi praktik pengauditan.

Perubahan proses dalam SIA akan mempengaruhi proses audit karena audit merupakan suatu bidang praktik yang menggunakan laporan keuangan (produk akuntansi) sebagai objeknya. Sehinga kemajuan IT juga akan menghasilkan software yang memungkinkan adanya proses audit. Ke depannya, akuntan akan menjadi profesi yang aktivitasnya banyak berhubungan dengan IT. Perkembangan SIA dan proses audit sebagai akibat dari adanya kemajuan IT dan perkembangan akuntansi akan memunculkan peluang bagi akuntan. Peluang ini dapat dimanfaatkan oleh akuntan yang mempunyai pengetahuan memadai tentang SIA dan audit berbasis komputer. Sebaliknya, akuntan yang tidak mempunyai pengetahuan yang cukup tentang SIA dan audit berbasis komputer akan tergusur posisinya karena tidak mampu memberikan jasa yang diperlukan oleh klien.

Saat ini, kita sudah banyak melihat munculnya istilah enterprise systems, e-business, business intelligence, conforming to assurance and compliance standards, IT governance, business 
continuity management, privacy management, business process improvement, mobile and remote computing, $X B R L$, dan knowledge management yang menunjukkan bahwa dunia akuntansi akan semakin kompleks di masa depan. Perkembangan ini tidak lantas membuat akuntansi menjadi semakin rumit dipelajari, tetapi membuat dunia akuntansi lebih menarik. Dari perkembangan ini pula, peran dan fungsi akuntan dapat meliputi tiga bidang: perancang, pengguna dan pemeriksa (auditor). Dalam ketiga peran ini, akuntan akan sangat membutuhkan TI akan dalam meningkatkan kualitas kerjanya.

Pada saat ini, beberapa teknologi informasi akuntansi mulai dari yang berbasis aplikasi komputer (seperti Zahir Accounting, MYOB, MOAE, dll) sampai yang berbasis aplikasi cloud (seperti [highlights]Akuntansionline.id[/highlights], Oracle dII) sudah banyak muncul di masyarakat (Baca juga [highlights] Tools Accounting[/highlights]). Untuk sebuah perusahaan besar, biasanya mereka akan menggunakan aplikasi akuntansi berbasis software. Hal ini dikarenakan, perusahaan tidak ingin mengambil resiko jika menggunakan software akuntansi berbasis cloud. Meskipun demikian, harga software akuntansi juga lebih mahal jika dibandingkan dengan yang berbasis cloud. Sedangkan penggunaan aplikasi akuntansi berbasis cloud seperti [highlights]Akuntansionline.id[/highlights] lebih banyak digunakan oleh perusahaan kecil dan menengah (Baca juga: [highlights]Manfaat Akuntansi Bagi UKM[/highlights]). Kelebihan dari aplikasi berbasis cloud ini adalah lebih ringan dan tidak memiliki sistem yang kompleks. Meskipun sederhana tetapi fiturfitur yang ada tidak mengurangi prinsip akuntansi yang sebenarnya. Sehingga lebih mudah dipahami dan digunakan. 


\subsection{Sistem Pelaporan Keuangan Berbasis XBRL}

XBRL adalah kependekan dari eXtensible Business Reporting Language. XBRL merupakan bahasa baku pelaporan bisnis berbasis XML yang dikembangkan untuk memfasilitasi komunikasi data bisnis dan data keuangan secara elektronis. XML sendiri, singkatan dari extensible Markup Language, adalah bahasa penanda (markup language) yang telah menjadi standar universal penyajian informasi terstruktur. XBRL bisa dikatakan versi XML yang khusus dimaksudkan untuk memenuhi kebutuhan pelaporan keuangan dan bisnis.

Menurut Phillips, Bahmanziari, dan Colvard (2008) menjelaskan ; XBRL menjadi cara baru perusahaan dan organisasi lainnya dalam mentransmisi dan menggunakan data bisnis. Contohnya, perusahaan-perusahaan terbuka di Amerika Serikat telah mengirimkan laporan-laporannya kepada otoritas bursa di sana (SEC) dalam format XBRL. Menurut Phillips, Bahmanziari, dan Colvard, usaha menengah dan kecil serta profesi akuntansi tidak bisa lagi menghindari dari tren XBRL. Meskipun tidak gencar terdengar, otoritas perbankan, bursa efek, dan otoritas pasar modal di Indonesia saat ini tengah mengarah kepada implementasi XBRL.

\section{Perkembangan XBRL}

XBRL International (XII) adalah organisasi konsorsium yang bersifat nirlaba, mencakup lebih dari 600 perusahaan dan badan lainnya. XII inilah yang mengembangkan XBRL serta mendorong adopsi XBRL secara global. Meskipun demikian, XBRL merupakan 
open standard technology. Setiap perusahaan atau penyedia perangkat lunak bisa menggunakan XBRL secara gratis.

Wada (2013) menjelaskan, pada awalnya XBRL memang dikembangkan sebagai teknologi untuk pelaporan keuangan atau pelaporan bisnis. Akan tetapi, penerapan XBRL terus diperluas sehingga mencakup juga informasi non-keuangan yang bersifat kualitatif. Contoh penerapan XBRL untuk pelaporan non-keuangan adalah penggunaan XBRL dalam penyampaian laporan tanggung jawab sosial perusahaan, inisiatif IIRC (International Integrated Reporting Council), dan GRI (Global Reporting Initiative) di wilayah Asia.

\section{Bagaimana Wujud konkret, XBRL?}

Salah satu artikel dari XII (diakses tanggal 2 Januari 2014) memberikan contoh script XBRL. XBRL terdiri dari tag-tag pengidentifikasi (identifying tags). Tag-tag pengidentifikasi itu diterapkan terhadap item-item data tertentu, sehingga dapat diproses secara efisien oleh perangkat lunak komputer. Contoh item data dimaksud adalah beban penyusutan atau laba bersih. Tag pengidentifikasi juga bisa menyajikan informasi yang lebih kompleks, misalnya angka dalam satuan moneter, angka persentase, dan angka pecahan. Lebih lanjut, XBRL juga memungkinkan pemberian label/nama suatu item data dalam bahasa apa pun, penggunaan kerangka acuan akuntansi yang berbeda-beda, serta penyediaan informasi lain terkait perusahaan anak. 
XBRL mampu menunjukkan keterkaitan item-item data satu sama lain. Dengan demikian, XBRL mampu menunjukkan bagaimana penghitungan yang mendasari suatu item data. XBRL juga mampu mengelompokkan item-item data menurut organisasi atau menurut tujuan pelaporan tertentu. Dan yang terpenting, XBRL dapat dengan mudah diperluas (extensible), sehingga perusahaan dan organisasi lainnya bisa mengadaptasi XBRL untuk memenuhi kebutuhan-kebutuhan khusus.Informasi dikonversi menjadi XBRL melalui proses pemetaan atau dibuat dalam format XBRL dengan perangkat lunak. Selanjutnya, informasi itu dapat ditelusuri, dipertukarkan, dan dianalisis dengan bantuan komputer atau dipublikasikan secara rutin.

XBRL menggunakan semacam kamus (dictionaries) yang berisi elemen-elemen XBRL dan dikenal dengan Taksonomi XBRL (XBRL Taxonomies). Taksonomi XBRL merupakan skema pengelompokan yang menetapkan tag-tag tertentu untuk masingmasing item data. Sebagai contoh, dalam laporan keuangan berbasis IFRS tag XBRL Other Reserves merepresentasikan pos Other Reserves.

Masing-masing negara memiliki aturan akuntansi yang berbeda-beda. Akibatnya, masing-masing negara akan memerlukan taksonomi pelaporan keuangan sendiri-sendiri. Berbagai organisasi, termasuk regulator, asosiasi industri, atau perusahaan induk, bisa juga memerlukan taksonomi XBRL khusus untuk memenuhi kebutuhan pelaporan bisnis mereka sendiri. Taksonomi khusus juga telah dirancang untuk memfasilitasi penggabungan data serta pelaporan internal di dalam organisasi. Taksonomi khusus dimaksud adalah GL Taxonomy. Phillips, 
Bahmanziari, dan Colvard (2008) menegaskan bahwa untuk membuat dokumen XBRL, kita tidak perlu belajar XML. Perangkat lunaklah yang melakukan proses pembubuhan tag dan mengirimkan dokumen XBRL antar-pihak yang terkait dalam sistem pelaporan berbasis XBRL.

\subsection{Bagaimanakah XBRL di Indonesia?}

Data keanggotaan XII (diakses tanggal 19 Januari 2014) memuat Bank Indonesia (BI) sebagai anggota langsung (direct member) XII. XII memang menawarkan dua opsi keanggotaan: Direct Membership dan Jurisdictions Membership. Bank Indonesia sejauh ini bisa dikatakan menjadi satu-satunya lembaga dari Indonesia yang berpartisipasi dalam pengembangan standar global pelaporan bisnis secara elektronis yang dipelopori XII.

BI (2013) menyatakan, XBRL pada awalnya diterapkan dalam penyampaian Laporan Bulanan Bank Umum Syariah (LBUS), Implementasi XBRL di BI dikatakan sebagai bagian dari penyiapan infrastruktur dalam rangka pengalihan fungsi regulasi dan pengawasan bank syariah dari BI ke OJK.

Wada (2013) dalam paparannya mengenai XBRL di Asia dan Oceania menyinggung implementasi XBRL di Indonesia. Wada (2013) menyatakan bahwa proyek XBRL Bank Indonesia dilatarbelakangi oleh timbulnya tuntutan informasi baru bagi perbankan syariah dalam rangka mengakomodasi standar akuntansi keuangan syariah, mematuhi ketentuan regulasi, mengakomodasi munculnya produk-produk baru perbankan 
syariah, serta memenuhi kebutuhan statistik moneter dan statistik sistem pembayaran.

Wada (2013) juga menjelaskan bahwa proyek XBRL BI dimaksudkan untuk mempersiapkan transisi pengawasan keuangan dari BI ke OJK pada tahun 2014. Proyek XBRL BI merupakan bagian dari upaya pengembangan sistem pelaporan keuangan yang akan mengakomodasi kebutuhan informasi BI dan OJK, misalnya yang berupa Laporan Stabilitas Moneter dan Sistem Keuangan (LSMK). 


\section{DAFTAR PUSTAKA}

Baridwan, Zaki. 1999. Sistem Akuntansi Penyusunan Prosedur dan Metode. Yogyakarta: BPFE

Barry E. Cushing, (Diterjemahkan oleh Drs. Ruchyat Kosasih), Sistem Informasi Akuntansi dan Organisasi Perusahaan, Edisi ke 3, Penerbit Erlangga, Jakarta, 1986.

Cecil Gillespie, Accounting Systems - Procedures and Methods, Prentice Hall of India Private Limited, New Delhi, 3th. Edition, 1985

George, H. Bodnar, William S. Hopwood, Accounting Information Systems, Allyn \& Bacon Inc., $4^{\text {th }}$ edition, 1990.

Jogiyanto H.M., Sistem Informasi Akuntansi Berbasis Komputer - Buku 1: Konsep dasar dan Komponen, BPFE UGM Yogyakarta, Yogyakarta, 1988

Joseph J. Wilkinson, Accounting Information Systems, John Willey \& Sons, $2^{\text {th }}$ edition, 1986.

Mulyadi, Sistem Akuntansi, Edisi 3, bagian Penerbitan YKPN STIE Yogyakarta, Yogyakarta, 1993

O'Brien, J.A. \& Marakas, G.M. (2006). Introduction to Information Systems, $7^{\text {th }}$ Ed., McGraw-Hill/Irwin. New York 


\section{BIODATA PENULIS}

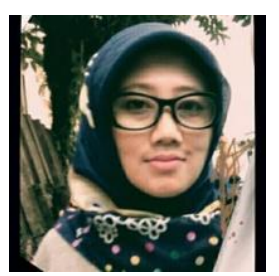

Imelda Dian Rahmawati.,SE.M.Ak.Ak. Lahir di Sidoarjo 13 Oktober 1978. Menyelesaikan pendidikan S1 di Fakultas Ekonomi Program Studi Akuntansi Univeristas Brawijaya Malang pada tahun 2002. Selanjutnya menyelesaikan pendidikan S2 Magister Ilmu Akuntansi pada tahun 2011 di Universitas Airlangga Surabaya. Dan sekarang sedang studi S3 Program Doktor IImu Akuntansi di Universitas Airlangga Surabaya. Saat ini penulis menjadi dosen tetap di Fakultas Ekonomi dan Bisnis Universitas Muhammadiyah Sidoarjo sejak tahun 2002 sampai sekarang. Dengan perkembangan tekhnologi informasi yang begitu cepat, SIA perusahaan juga harus menyesuaikan agar pengendalian intern bisa berjalan maksimal. Selain Akuntansi Islam yang menjadi concern penulis, adalah Sistem Informasi Akuntansi. SIA ini sangat menunjang penulis didalam mendesain sistem informasi keuangan dan Pengendalian Intern UMSIDA. Semoga Buku Ajar ini bisa memberikan manfaat bagi perkembangan Sistem Informasi Akuntansi di Indonesia. 


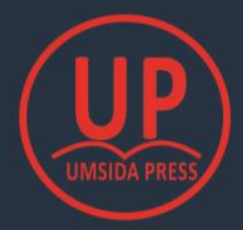

UMSIDA PRESS

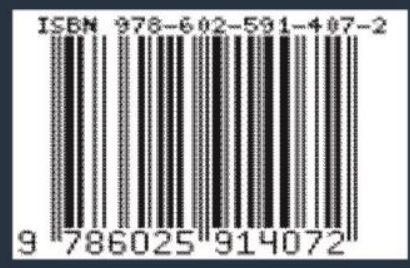

JI. Mojopahit 666 B Sidoarjo 